\title{
A new bivalve community from the lower Ludlow of the Prague Basin (Perunica, Bohemia)
}

\author{
JIŘí KŘíž
}

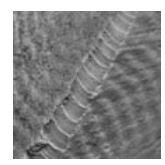

The new shallow-water Bivalvia Janicula potens Community from the lower Gorstian carbonate platform influenced by the Svatý Jan Volcano activity in the Prague Basin, Bohemia is composed of 32 species [Slava sathon Křřž, 1985 (Slavidae); Cardiola donigala Kř́žž in Kř́̌ž \& Serpagli, 1993, Cardiola signata Barrande, 1881, Cardiola aff. geminans Barrande, 1881 (Cardiolidae); Dualina amina sp. nov. (Antipleuridae); Mila parvula Křriž in Kříž \& Serpagli, 1993 (Stolidotidae); Algerina aff. algena Kř́̌ž, 2008, Tetinka costulifera sp. nov. (Spanilidae); Macrodesma enigma sp. nov. (Cyrtodontidae); Phthonia regularis (Barrande, 1881) (Mytilidae); Ambonychia volitans (Barrande, 1881), Amphicoelia pojetana sp. nov., Mytilarca parens (Barrande, 1881), Mytilarca sp. (Ambonychiidae); Molinicola bohemica sp. nov. (Pterineidae); Palaeopecten radvani sp. nov., Palaeopecten sp. (Leiopectinidae); Rhombopteria perunicola sp. nov. (Rhombopteriidae); Praeostrea bohemica Barrande, 1881 (Praeostreidae); Butovicella migrans (Barrande, 1881) (Butovicellidae); Mimerodonta phaseolus sp. nov., Janicula potens (Barrande, 1881), Goniophora tyri Liljedahl, 1984, Goniophora ascia sp. nov., Goniophora compta sp. nov., Goniophora solci sp. nov., Goniophora sp. (Modiomorphidae); Goniophorina nitidula sp. nov. (Goniophorinidae); Cymatonota prolata sp. nov., Cimitaria liscina sp. nov., Cimitaria cf. liscina sp. nov., Sanguinolites? drupa sp. nov. (Grammysiidae)]. In the paper one new genus (Janicula gen. nov.), and 15 new species are described. The Janicula potens Community occupied the environment of protected well-ventilated shallow-water flats, locally overgrown by algae, with carbonate sedimentation influenced by direct ash falls and the subsequent sedimentation of volcaniclastics by currents around the volcanic archipelago. It is accompanied by a rich benthos, especially crinoids, corals, gastropods, and brachiopods together with abundant trilobites, rostroconchids, common cephalopods, stromatoporids, relatively rare ostracods, tergomyans, polyplacophorids, worms, bryozoans, sponges, and algae. It is classified as a part of the Coral-Crinoid Community Group which in the Prague Basin, Bohemia includes the homologous and analogous late Homerian, Wenlock Coral-Leptaenid Community, Hircinisca-Ancillotoechia Community, and Septatrypa lissodermis-Cyrtia maior Community, the early Gorstian, Ludlow Atrypa fumosa Community, and the Coniproetus-Protocymostrophia Community. The Janicula potens Community from the Liščí Quarry locality near the Amerika gamekeeper's lodge north of Karlštejn, Bohemia is the most diversified Bivalvia community in the Silurian of the Prague Basin. The lower Gorstian tuffaceous limestones, with more than 202 benthic and nektobenthic known species, represent the most fossiliferous Silurian level in the Prague Basin. The Janicula potens Community shows close palaeogeographic relationships with the upper Wenlock, Racine Formation reefs of Wisconsin and Illinois (North America), Silurian of Gotland and Dalarna (Sweden), Maine (North America), and Nova Scotia (Canada). Key words: Bivalvia, Silurian, lower Ludlow, new taxa, palaeoecology, shallow water, volcaniclastics, Perunica, Prague Basin, Bohemia.

KŘíž, J. 2008. A new bivalve community from the lower Ludlow of the Prague Basin (Perunica, Bohemia). Bulletin of Geosciences 83(3), 237-280 (12 figures, 2 tables). Czech Geological Survey, Prague. ISSN 1214-1119. Manuscript received June 30, 2008; accepted in revised form August 12, 2008; issued September 30, 2008.

Jiři Kř̌̌z, Czech Geological Survey, Klárov 3, P.O. Box 85, 11821 Praha 1, Czech Republic; jiri.kriz@geology.cz.

In the Prague Basin (Bohemia, Barrandian), the earliest Silurian sediments were pelitic. During the Telychian (Llandovery) and especially in the early Sheinwoodian (Wenlock) the carbonate admixture increased continuously. Since the Aeronian (Llandovery) the sedimentation in the Prague Basin was influenced by volcanic activity, accompanied by the production of volcaniclastic sediments, magma intrusions and effusions. Several volcanic centres existed along the deep synsedimentary growth faults and their zones of intersection (Kř́ř 1991, 1998). In the Prague Basin the volcanic archipelago developed at these volcanic centres: Hýskov Volcano (Aeronian), Svatý Jan Volcano (late Sheinwoodian-Gorstian), Reporyje Volcano (Sheinwoodian and early Homerian), Kosov Volcano and Nová Ves Volcano (latest Homerian-early Gorstian).

The sedimentation and redeposition of volcaniclastics by currents near the volcanic archipelago led to the origin of well-ventilated shallow-water flats with carbonate 


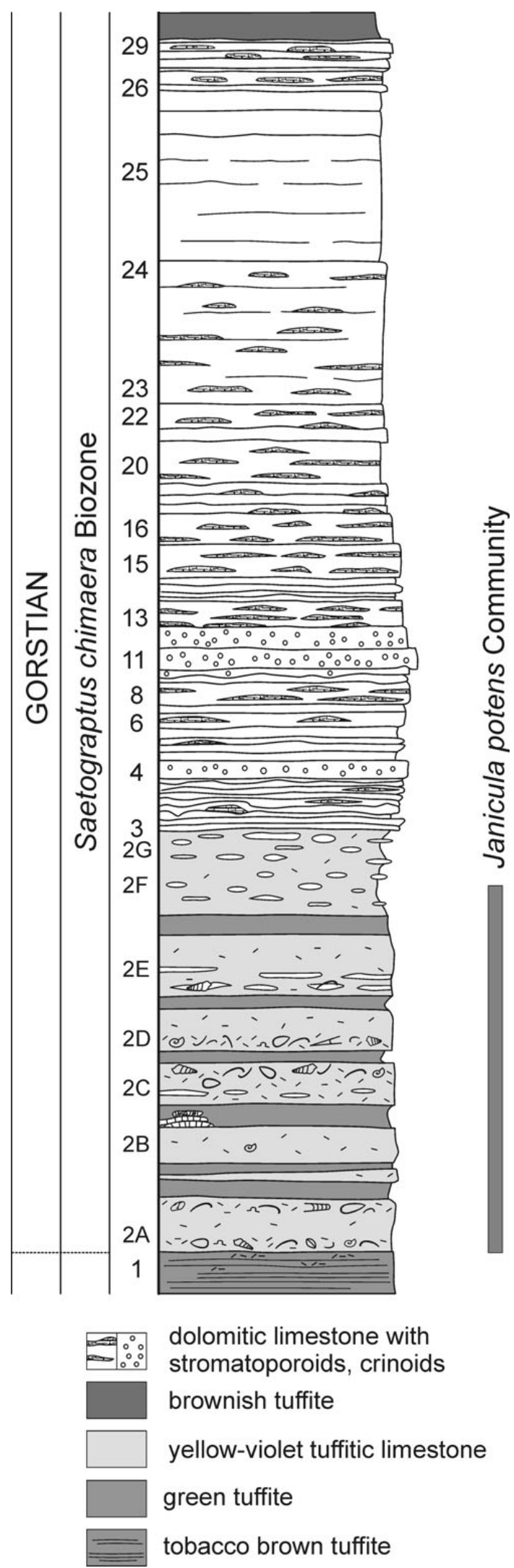

Figure 1. Liščí Quarry near Amerika gamekeeper's lodge, Karlštejn, Prague Basin, Bohemia, section No. 942 showing lithologies. sedimentation, overgrown by algae, and occupied by a rich benthos, especially crinoids, corals, stromatoporoids, brachiopods, gastropods, and bivalves. Bioclasts formed a substantial proportion of the sediments. In the periods of volcanic activity and subsequent deposition of volcaniclastics, the tuffaceous admixture in the sediments increased. During the late Wenlock the Svatý Jan Volcano emerged. A rich assemblage of early land plants is documented by a rich occurrence of trilete miospores and cryptospores in the littoral sediments around the island. The assemblage of the sporomorphs is comparable with the assemblage of almost the same species described from Shropshire (Ǩř́ž 1992, Křiž et al. 1993, Dufka 1995).

In sediments of the carbonate platforms developed on slopes of the Svatý Jan Volcano in the lower Homerian, Wenlock, a crinoid, gastropod, bivalve, brachiopod and trilobite-rich fauna occurs at the localities in the Section Loděnice - Bubovice (Křǐž 1992), Svatý Jan - Hliník (Horný 1955), Tachlovice - Section No. 713 (Křǐž et al. 1993), Lištice (Herinky) and Kozel near Beroun - Section No. 960 (Kř́̌̌ 1992), and was described already by Barrande in his "Systême silurien du centre de la Bohême" (1852-1881). From these localities Barrande described (1881) a rich assemblage of bivalves dominated by pterineids, pectinoids, ambonychiids, and modiomorphids. They usually occur together with the rich communities of gastropods described for the Systême silurien du centre de la Bohême by Perner (1903-1911).

A similar rich coral, stromatoporoid, gastropod, bivalve, brachiopod and crinoid fauna of the early Ludlow age was discovered in 1929 (Bouček 1931) in the new quarries near the Amerika gamekeeper's lodge north of Karlštejn in the southern vicinity of the Silurian Svatý Jan Volcano. In the Amerika Anticline the lower Gorstian tuffaceous partly unconsolidated carbonates were exposed. They originated on the shallow-water protected flats built by the Wenlock tuffites and overgrown by algae, important for development of the rich gastropod, brachiopod and bivalve communities. The general composition of these communities is very similar to that of the communities known from the older rocks of Wenlock age to Barrande.

The rich fauna from the quarries in the Amerika Anticline was carefully collected for many years and only slowly scientifically analysed. Prantl (1939a, b) described three new species of rugose corals from the locality. Přibyl (1943) correlated the levels with the early Ludlow (Neodiversograptus nilssoni - Saetograptus chimaera Biozone) and described from here the characteristic brachiopod Kirkidium (Pinguaela) bohemicum (Přibyl, 1943). Růžička \& Bouška (1944) published on the activities and the collections from this locality in 1929-1944, and listed 125 species of crinoids (17), trilobites (11), cephalopods (6), gastropods (28), bivalves (6), brachiopods (21), bryozoans (3), corals (29), stromatoporoids (3) and algae (1). 


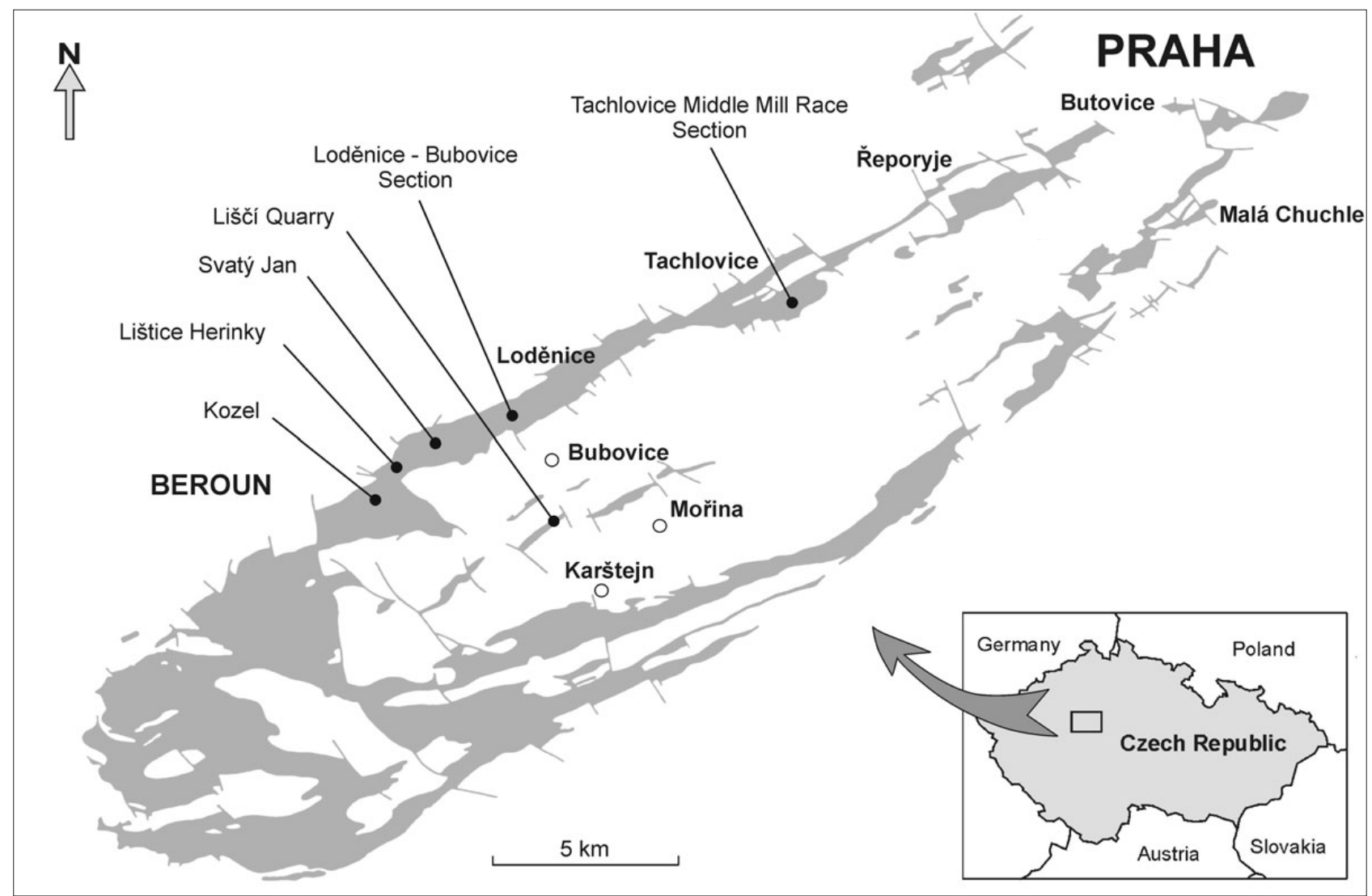

Figure 2. Distribution of the Silurian rocks in the Prague Basin and the location of the localities discussed in the text.

Horný (1952) published first detailed description of the gastropod-rich locality Liščí Quarry and in 1955 described the Wenlock-Ludlow section in the region of Amerika Anticline near Karlštejn and also a first detailed list of fauna (more than 127 species) of the gastropod-rich tuffaceous rocks. Svoboda \& Prantl (1955) discussed the section and fauna in the Amerika quarries, and Prantl (1957) described from here Helmintidium mirum bohemicum Prantl, 1957 and the list of corals from the locality (more than 23 species). Kř́̌ž (1986) compiled the most recent list of fauna from the locality, and Havlíček \& Štorch (1990) re-described the brachiopods and defined from here the Coral-Crinoid Community. Horný \& Peel (1995) estimated more than 60 species of gastropods from the locality Liščí Quarry.

The locality represents the most fossiliferous Silurian locality in the Prague Basin. From the "gastropod levels" in Liščí Quarry are known more than 202 species, consisting of crinoids (12), ostracods (2), trilobites (11), cephalopods (13), gastropods (60), bivalves (32), rostroconchids (4), tergomyans (1), polyplacophorids (1), worms (1), bryozoans (3), brachiopods (26), corals (31), stomatoporids (3), algae (1) and sponges.

Radvan Horný from the National Museum, Prague collected at the Liščí Quarry locality near the Amerika gamekeeper's lodge in the period 1952-1998, and measured the gastropod rich levels of the tuffaceous limestones in detail in 1964, in 1995 (levels A-G), and in 1998 (level A). Jiří Kř́iž collected bivalves at the locality in the period 1961-1966 and measured exposed section No. 942 (Fig. 1) in the southern slope of the Liščí Quarry in 1977. The statistics of the bivalve community are based on the all bivalves collected from the layer No. 2 (section No. 942). The distribution of bivalves in the levels A-E of the bed No. 2 (Tables 1,2) is based on the collections from the period 1965-1966.

The section No. 942 (coord. $49^{\circ} 57^{\prime} 17.2^{\prime \prime} \mathrm{N} ; 14^{\circ}$ $\left.10^{\prime} 23.1^{\prime \prime} \mathrm{E}\right)$ starts by the tobacco-brown tuffites with fragments of benthic fauna in upper part (bed No. 1).

They are overlain by $555 \mathrm{~cm}$ thick formation of the yellow, brown, violet and rusty, partly unconsolidated limestone with tuffaceous admixture and volcanic glass. Horný (1998) collected in the formation also common irregularly shaped volcanic bombs up to $15 \mathrm{~cm}$ in diameter. Beds, 15 to $30 \mathrm{~cm}$ thick, of light green tuffite contain lapilli (up to 10 millimetres in size), and divide the bed No. 2 into six levels $(A-G)$. The tuffaceous limestones contains crinoid, coral, bivalve, brachiopod and gastropod fauna accompanied by cephalopods, trilobites and other benthic groups described above. Accumulations of gastropods are developed at the base and in the upper part of the level A, and at the base of the levels $\mathrm{B}$ and $\mathrm{C}$ occur large tabulate 
(favositids, heliolitids, chaetetids) and rugose coral colonies (Microplasma flexuosum Prantl, 1939a). In the level $\mathrm{C}$, and in the middle part of the level D abundant bivalves, gastropods and brachiopods occur. In the levels E, F, and G the tabulate coral colonies became locally abundant.

Higher up is $127 \mathrm{~cm}$ thick formation of 7-17 cm thick lenticular layers (beds No. 3-5) of the brown to pinkish lenticular limestones, alternating with grey-green to greenish grey tuffites with abundant stromatoporoid colonies and tuffaceous limestones.

The section continues with the $900 \mathrm{~cm}$ thick formation of 6-180 cm thick layers (beds No. 6-30) of mostly massive pinkish grey, greyish brown to rusty brown biodetrital dolomitic limestones with crinoid detritus and stromatoporoid colonies. This formation may be correlated with the biodetrital pinkish crinoidal dolomitic limestones with tabulates and stromatoporoid colonies between the two tuffitic levels exposed in western part of the Liščí Quarry, macroscopically and microscopically described by Kukal (1955, formation No. 3, $11 \mathrm{~m}$ thick, p. 248).

The sequence No. 942 is terminated by greenish tuffites (bed No. 31) and higher up it is covered by the quarry scree.

\section{Systematic palaeontology}

Abbreviations. $-\mathrm{V}=$ valve, $\mathrm{L}=$ length of the shell, $\mathrm{H}=$ height of the shell, $\mathrm{W}=$ width of the shell, W/2 = width of one valve (Kř́ǐ 1969); JK 95, JK 142, JK 3291, JK 8535, JK 11499-JK 11980 bivalves (1900 specimens) deposited in the collection of Jiří Kříž in the Czech Geological Survey, Prague; NM bivalves deposited in the National $\mathrm{Mu}-$ seum, Prague. All measurements are in millimetres.

Class Bivalvia Linné, 1758

Subclass Autolamellibranchiata Grobben, 1894

Superorder Nepiomorphia Kříž, 2007

Order Praecardioida Newell, 1965

Superfamily Cardioloidea Hoernes, 1884

Family Slavidae Kř́ž, 1982

\section{Genus Slava Barrande, 1881}

Type species. - Slava bohemica Barrande, 1881, Bohemia, Prague Basin, Silurian, Ludlow, Gorstian.

\section{Slava sathon Kříž, 1985}

Figure 3A, B

1985 Slava sathon sp. n.; Křriž, p. 74-77, pl. 9, figs 1-9, pl. 11, figs 1, 2, 10, 11.

1993 Slava sathon Kříž. - Kříž in Kř́ž \& Serpagli, p. 325, pl. 7, figs 1, 2, 23.

1996 Slava sathon Křǐž. - Kříž, p. 50, pl. 5, figs 14, 18, 23.
Holotype. - Internal mould of a left valve with fragments of the shell, JK 3288, figured by Kř́̌ž (1985) on pl. 9, figs 7, 9.

Type locality. - Bohemia, Praha-Malá Chuchle Valley.

Type horizon. - Silurian, Wenlock, Homerian, Testograptus testis Biozone.

Material. - One incomplete right valve.

Dimensions. -

$\begin{array}{lllll}\text { specimen } & \mathrm{V} & \mathrm{L} & \mathrm{H} & \mathrm{W} / 2\end{array}$

$\begin{array}{lllll}\text { JK } 3291 & \text { R } & 18.0 & 23.2 & 9.2\end{array}$

Discussion. - In its general shape, outer and inner surface sculpture, and ontogeny the specimen from the Liščí Quarry locality is conspecific with type material (Kříž 1985) from the lower Ludfordian of the Prague Basin.

Mode of life. - Endobyssate, infaunal (Kř́ǐ̌ 1985).

Occurrence. - Slava sathon occurs in the Prague Basin, Bohemia from the upper Wenlock, Homerian up to the lowermost Ludfordian (Ludlow). It is a common species in the Bivalvia-dominated Cardiola donigala-Slava sathon Community described from the lower Gorstian of the Prague Basin (Manda \& Kř́ž 2007). It was also described from the Cardiola docens Community, lower Ludfordian of Sardinia, Galemmu locality near Fluminimaggiore (Kř́ž in Křiž \& Serpagli 1993) and from the upper Wenlock, Homerian of Montagne Noire, France, Roquemaillére locality near Gabian (Kříž 1996).

Family Cardiolidae Hoernes, 1884

\section{Genus Cardiola Broderip in Murchison, 1839}

Type species. - Cardiola interrupta Sowerby in Murchison, 1839, Great Britain, Wales, Radnor Forest, New Radnor, Silurian, Ludlow.

Cardiola donigala Kř́ǐ̌ in Kř́íz \& Serpagli, 1993 Figure 3C-F

1993 Cardiola donigala sp. n.; Kř̌iž in Křriž \& Serpagli, p. 316, pl. 5, figs 4-7, 10, 11.

1996 Cardiola donigala Kř́ž. - Křǐž, p. 45, pl. 2, figs 19, 22-25, 28-30, pl. 3, figs 1-6.

Holotype. - Left valve, deposited in the Paleontological Institute, University of Modena under the number MO 23050 . 
Type locality. - Italy, Sardinia, S'Antonio Donigala.

Type horizon. - Silurian, Ludlow, lower Gorstian, most probably the Saetograptus chimaera Biozone.

Material. - One right, and five left valves.

\section{Dimensions.-}

specimen

JK 11565

V

$\mathrm{L}$

$\mathrm{L}$

10.0

$\mathrm{H}$

12.1

$\mathrm{W} / 2$

Discussion. - In their general shape, outer and inner surfaces sculpture, and ontogeny the specimens from the Liščí Quarry locality are conspecific with type material from the Gorstian (Ludlow) of Sardinia. They are also conspecific with the specimens from the Gorstian of Bohemia. Cardiola sp. described from the upper Wenlock, Racine Formation reef dolostone of Wisconsin and Illinois, North America (Watkins 1997) is a member of the Cardiola agna - Cardiola gibbosa - Cardiola donigala - Cardiola docens lineage (Kř́ž 1979) and it is closely related to Cardiola donigala by general shape and surface sculpture.

Mode of life. - Cardiola donigala was epibyssate, attached to the firm substrate, most probably to the empty cephalopod shells or to the biodetrite on the bottom (Křiž 1979) in the cephalopod limestone biofacies.

Occurrence. - Cardiola donigala is a dominant species of the Cardiola donigala Community described from the lower Gorstian (Ludlow) of Sardinia (Kříž in Kř̌ž \& Serpagli (1993). It is also dominant species of the Cardiola donigala-Slava cubicula Community described by Kříž (1999b) from the cephalopod limestone biofacies on the northern slopes of the Svatý Jan Volcano, the upper Saetograptus chimaera Biozone, upper Gorstian and of the Cardiola donigala - Slava sathon Community described from the cephalopod limestone biofacies on the slope of volcanic accumulation near Prague, the lower Saetograptus chimaera Biozone, lower Gorstian (Manda \& Kříž 2007).

\section{Cardiola signata Barrande, 1881}

Figure 3G-J

1881 Cardiola signata Barr.; Barrande, pl. 167, figs V/9-23, 32-34, 37-42.

1979 Cardiola signata Barrande. - Křřž, pp. 86, 87, pl. 19, figs 2,3 , pl. 39 , fig. 4 (for a complete previous synonymy see this paper).

1993 Cardiola signata Barrande. - Kříž in Kříž \& Serpagli, pp. 318,319 , pl. 6, fig. 21.

1995 Cardiola signata Barrande. - Kříž \& Bogolepova, pp. 577,578 , pl. 70, figs $6,8,10,13,16$.
1996 Cardiola signata Barrande. - Kříž, p. 46, pl. 3, figs 9, 12, 13, 17.

1999c Cardiola signata Barrande. - Kř̌žz, p. 283, pl. 5, figs 21, 27, 28, pl. 6, figs 1-3.

Lectotype. - Designated by Kř́ž (1979). Left valve, deposited in the National Museum, Prague under the number L 7249, and re-figured by Kříž (1979) on pl. 19, figs 2,3 .

Type locality. - Bohemia, Koněprusy near Beroun.

Type horizon. - Silurian, Ludlow, lower Ludfordian.

Material. - Two right valves.

Dimensions.-

$\begin{array}{lllll}\text { specimen } & \text { V } & \text { L } & \text { H } & \text { W/2 }\end{array}$

$\begin{array}{lllll}\text { JK } 11569 & \mathrm{R} & 5.1 & 7.9 & 2.7\end{array}$

$\begin{array}{lllll}\text { JK } 11570 & \mathrm{R} & 7.5 & 8.4 & 3.5\end{array}$

Discussion. - From their general shape, outer and inner surfaces sculpture, and ontogeny the specimens from the Liščí Quarry locality are conspecific with Barrande's type material from the Gorstian and the Ludfordian (Ludlow) of Bohemia.

Mode of life. - Cardiola signata was epibyssate, attached to the firm substrate, most probably to the empty cephalopod shells or to the biodetritus on the bottom in the cephalopod limestone biofacies.

Occurrence. - Cardiola signata represents a cosmopolitan cardiolid. It is a dominant species of the Cardiola signata Community described from the uppermost Gorstian cephalopod limestone biofacies (Saetograptus chimaera Biozone) of Tajmyr (Křiž \& Bogolepova 1995). The Cardiola signata Community was also described from the locality Mušlovka, Bohemia, from the cephalopod limestone biofacies, lower Ludfordian, lower part of the Saetograptus fritschi Biozone by Manda \& Budil (2007). In Bohemia Cardiola signata occurs in the Cardiola donigala-Slava cubicula Community described from the cephalopod limestone biofacies on the northern slopes of the Svatý Jan Volcano, upper Saetograptus chimaera Biozone, the upper Gorstian (Křǐž 1999b), from the Cardiola donigala-Slava sathon Community described from the cephalopod limestone biofacies on the slope of volcanic accumulation near Prague, lower Saetograptus chimaera Biozone, the lower Gorstian (Manda \& Kř́ž 2007) and from the Cardiola docens Community, Saetograptus fritschi Biozone, the lower Ludfordian.

Besides Bohemia and Tajmyr, it occurs in Poland (Wenlock); Germany (Lindener Mark, lower Ludlow), Austria 
(Carnic Alps, Wenlock - Ludlow boundary); Sweden, Gotland (Wenlock - Ludlow boundary), Skåne (Wenlock Ludlow boundary); France (Massif Armoricain, Wenlock Ludlow boundary); Massif de Mouthoumet and Montagne Noire, Wenlock - lower Ludlow); Portugal; Great Britain Welsh Borderland (Wenlock - Ludlow boundary); and Italy (Sardinia, Wenlock - Ludlow boundary).

\section{Cardiola aff. geminans Barrande, 1881}

Figure $3 \mathrm{~K}$

Material. - One right valve.

\section{Dimensions. -}

$\begin{array}{lllll}\text { specimen } & \text { V } & \text { L } & \text { H } & \text { W/2 }\end{array}$

$\begin{array}{lllll}\text { JK } 11614 & \text { R } & 14.3 & 17.7 & 8.0\end{array}$

Discussion. - Based on their general shape, outer and inner surface sculpture, and ontogeny the specimens from the Liščí Quarry locality are closely related to Barrande's holotype of Cardiola geminans Barrande, 1881 and other specimens, which are very rare in the lower part of the Ludfordian (Ludlow) of the Prague Basin, Bohemia.

Mode of life. - Cardiola aff. geminans was byssate, probably semi-infaunal.

Occurrence. - Cardiola geminans is known from the lower Ludfordian, Ludlow cephalopod limestone biofacies from the Prague Basin, Bohemia, locality Dlouhá Hora Hill near Beroun and from the Mušlovka Quarry near Praha-̌̌eporyje.

Order Antipleuroida Kříž, 2007

Superfamily Antipleuroidea Kř́̌ž, 2007

Family Antipleuridae Neumayr, 1891

\section{Genus Dualina Barrande, 1881}

Type species. - Dualina comitans Barrande, 1881, Bohemia, Prague Basin, Silurian, Ludlow, Ludfordian.

\section{Dualina amina sp. nov.}

Figure 3L-N, Q-T

Holotype. - The left upper valve from the shell inclined to the right, JK 11817, figured on Fig. 3Q-T.

Paratype. - The compressed shell with conjoined valves inclined to the right, JK 11573, figured of Fig. 3L-N.

Derivation of name. - Name derived from the Czech name Amina from the tale; indeclinable noun.

Type locality. - Bohemia, Karlštejn, Liščí Quarry near Amerika gamekeeper's lodge.

Type horizon. - Silurian, Ludlow, lower Gorstian, Kopanina Formation, section No. 942/2.

Material. - Types only.

Diagnosis. - Dualina of the Dualina longiuscula Barrande, 1881 group with small subtrigonal shells, shell length and width almost equal, inequivalve, compressed, and strongly enantiomorphous, distinctly inclined to the right, with flat, lanceolate frontal face. Anterior margin of the upper valve is almost straight, and in dorsoventral direction. On the anterior face of the shell are developed 18 radial ribs and 28 radial ribs developed in posterior part of the shell. Posterior wing is separated from the rest of the shell by shallow radial sinus.

Description. - Shell is small $(\mathrm{L}=12.6, \mathrm{H}=12.3, \mathrm{~W} / 2=4.0)$, subtrigonal, inequilateral, inequivalve, strongly enantiomorphous, inclined to the left and to the right, and inflated but laterally compressed $(\mathrm{H} / \mathrm{W}=1.53)$. Umbones are in anterior position, coiled, beaks prosogyrate. In the opisthocline upper valve (left valve) of the shell inclined to the right is developed a distinct, overhanging anterior face separated from the valve by a rounded umbonal ridge. Posterior of upper valve is twisted laterally up along wide, shallow radial sinus. Hinge line is very short, convex. Anterior margin of the upper valve formed by umbonal ridge

Figure 3. A, B - Slava sathon Kříž, 1985, right valve, JK 3291; A - dorsal view, × 2; B - lateral view, × 1.6. • C-F - Cardiola donigala Kříž, 1993; C, D - left valve, JK 11565; C - postero-lateral view, $\times 2.2$; D - lateral view, $\times 2.4$; E - left lateral view, JK 11567, × 3.5; F - left lateral view, JK 11568, $\times 3.1$ - G-J - Cardiola signata Barrande, 1881; G, H - right valve, JK 11569; G - lateral view, $\times 2.6$; H - antero-lateral view, $\times 2.5$; I, J - right valve, JK 11570; I - antero-lateral view, $\times 2.2 ; \mathrm{J}$ - lateral view, $\times 2.8 . \bullet \mathrm{K}-$ Cardiola aff. geminans Barrande, 1881, right valve, lateral view, JK $11614, \times 1.7$. - L-N - Dualina amina sp. nov., articulated specimen, JK 11573, paratype; L - left lateral view, $\times 2.7 ; \mathrm{M}-$ right lateral view, $\times 2.5 ; \mathrm{N}-$ ventral view, $\times 2.2$. $\bullet$ O, P - Dualina tenuissima Barrande, 1881, articulated specimen, NM L 14685, lectotype; O - right lateral view, $\times 1.7 ; \mathrm{P}-$ left lateral view, $\times 1.6$. - Q-T - Dualina amina sp. nov., left valve, JK 11817, holotype; Q - dorsal view, $\times 2.8 ; \mathrm{R}$ - detail of the outer surface sculpture in ventral part, $\times 4$; S - lateral view, × 2.3; T - ventro-lateral view, × 2.6. •U - Mila parvula Kř́̌ž, 1993, JK 11572, right lateral view, × 3.7. •V-Y - Algerina aff. algena Kř́ž, 2008, left valve, JK 11818; V - detail of the outer surface sculpture in ventral part, $\times 6.4 ; \mathrm{X}$ - detail of nepioconch, left lateral view, $\times 5.8 ; \mathrm{Y}-$ lateral view, $\times 3.4$. -Z-ZE - Tetinka costulifera sp. nov., articulated specimen, JK 11571, holotype; Z - dorsal view, $\times 4.6$; ZA - left view, $\times 4.4$; ZB - right view, $\times 4.4$; $\mathrm{ZC}$ - posterior view, $\times 4.4 ; \mathrm{ZD}-$ anterior view, $\times 4.4 ; \mathrm{ZE}-$ ventral view, $\times 6$. 


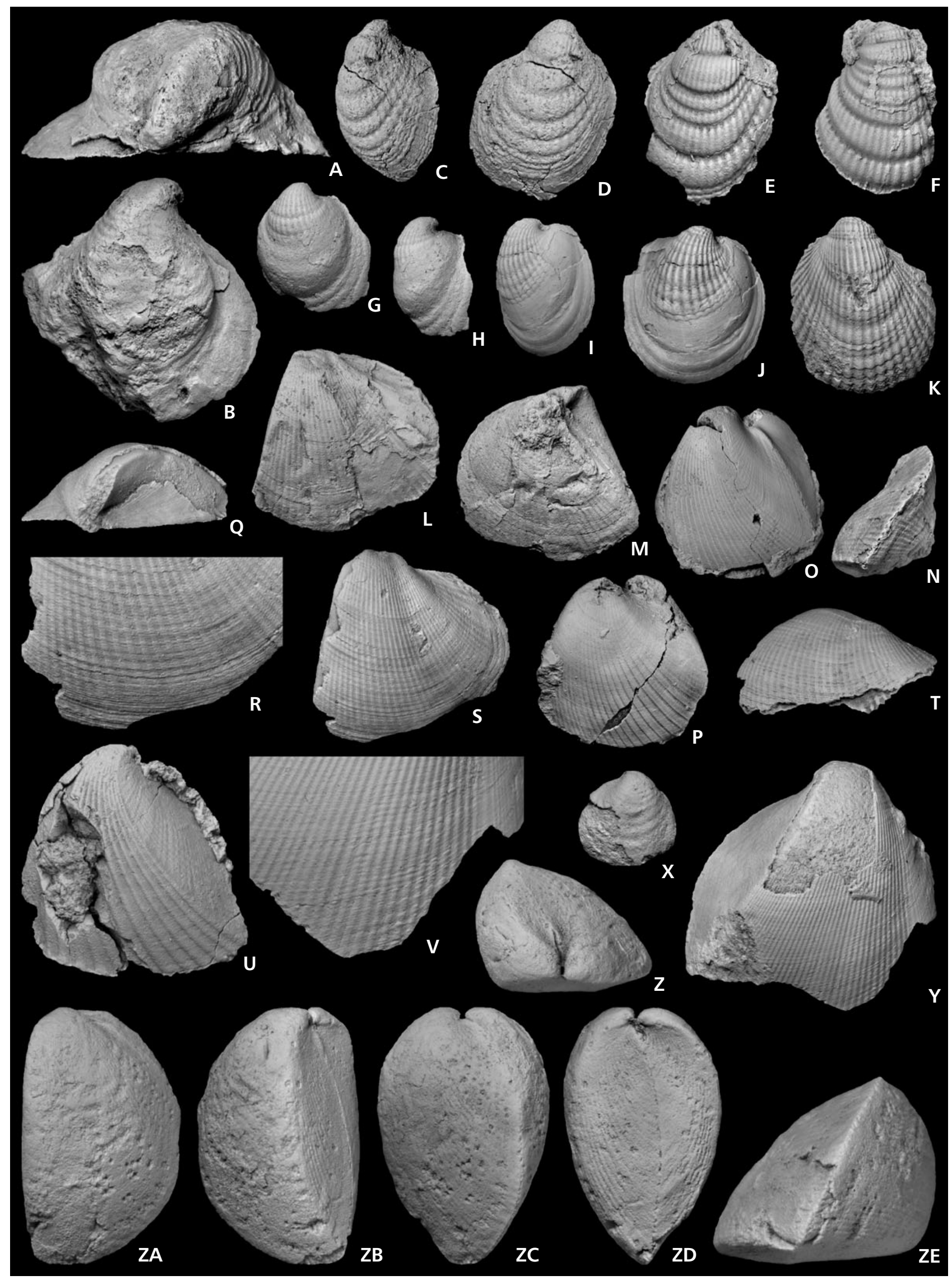


is almost straight in dorsoventral direction. Ventral end of anterior margin is angular. Ventral margin is evenly rounded and together with the posterior margin it forms the posterior rounded, wing-like part of shell. Outer surface sculpture consists of irregular growth wrinkles forming narrow growth bands and furrows in combination with 18 flat radial ribs on the anterior face, and about 28 on the rest of the valve. Radial ribs are less prominent on the anterior face of the upper valve and on the corresponding anterior part of the lower valve. Radial ribs are curved posteriorly in upper valve (left) and anteriorly in lower valve (right). Hinge is unknown, ligament opisthodetic.

\section{Dimensions. -} specimen JK 11817 V $\mathrm{L}$ $\mathrm{L}$ 12.3 $\mathrm{H}$ $\mathrm{W} / 2$ JK 11573 L $\quad 12.6$ 12.4 12.3

Discussion. - Lectotype (SD, herein) of Dualina tenuissima Barrande, 1881 [shell with conjoined valves inclined to the right deposited in the National Museum, Prague under the number L 14 685, figured by Barrande (1881) on pl. 34, figs I/20-26, and herein on Fig. 3O, P] differs from Dualina amina by a little dorsoventrally elongated shell, convex anterior margin, less numerous radial ribs in posterior part of the left (upper valve) and by generally higher number of convex radial ribs on the shell (about 39 in number). Dualina amina was one of the earliest representatives of the genus Dualina and was probably an ancestral form of Dualina tenuissima.

Mode of life. - Reclining, byssate, with posterior part close to the water-sediment interface.

Occurrence. - The descendant of Dualina amina - Dualina tenuissima represents a common species of the Bivalvia dominated communities in the Ludfordian (Ludlow) cephalopod limestone biofacies.

Family Stolidotidae Starobogatov, 1977

\section{Mila Barrande, 1881}

Type species. - Mila complexa Barrande, 1881, Bohemia, Prague Basin, Silurian, Ludlow, Ludfordian.

\section{Mila parvula Kříž in Kříž \& Serpagli, 1993}

Figure 3U

1993 Mila parvula Kříž; Křǐž in Kř́iž \& Serpagli, pp. 329, 330, pl. 8, figs 13,15-18, 20.
Holotype. - Left (lower) valve figured by Kříž in Kříž \& Serpagli (1993) on pl. 8, figs 15, 16, and deposited in the Paleontological Institute, University of Modena under No. MO 22970.

Type locality. - Italy, Sardinia, Fluminimaggiore, Galemmu locality.

Type horizon. - Silurian, Ludlow, lower Ludfordian, Cardiola docens Community.

Material. - One right (lower) valve.

Dimensions. -

$\begin{array}{lllll}\text { specimen } & \text { V } & \text { L } & \text { H } & \text { W/2 }\end{array}$

$\begin{array}{lllll}\text { JK } 11572 & \text { L } & 10.3 & 10.3 & 1.8\end{array}$

Discussion. - Enantiomorphous (Kř́žž 2001), right, lower valve of Mila parvula from the lower Gorstian, Liščí Quarry locality, represents probably the oldest known representative of the species. The shell is inclined to the right while the shells from Sardinia are all inclined to the left. The right lower valve is opisthodetic, umbo in posterior position and prosogyrate with coiled beak. A little inflated anterior face is separated from the rest of the shell by a distinct bend curved anteriorly, formed by the anterior-most wide radial rib. Posterior wing well developed, separated from the central part of the valve by shallow radial sinus. Outer surface sculpture is composed of growth wrinkles and irregular narrow growth bands in combination with radial ribs, convex in cross-section and wide radial gutters. Both, the radial ribs and radial gutters broaden ventrally and are anteriorly curved. The radial ribs are narrower and less prominent in frontal face of the valve. 12 radial ribs are developed between anterior bend and posterior sinus separating the wing. Number of radial ribs in Sardinian specimens is similar (13-17).

Mode of life. - Mila parvula was probably reclining, with posterior part close to the water-sediment interface.

Occurrence. - The cephalopod limestone biofacies of the lower Ludfordian (Ludlow) of the South-Western Sardinia, Fluminimaggiore, Galemmu locality.

Family Spanilidae Kříž, 2007

Genus Algerina Kř́̌́̌, 2008

Type species. - Algerina algena Kř̌̌ž, 2008, Algeria, Hoggar Mountains, Ahnet Massif, Foum Belrem Section, Silurian, Ludlow, lower Gorstian. 
Algerina aff. algena Kř́̌ž, 2008

Figure $3 \mathrm{~V}-\mathrm{Y}$

Material. - One incomplete left valve (lower) of the shell inclined to the left.

Discussion. - In its general size and shape, outer and inner surfaces sculpture, and ontogeny the specimen from the Liščí Quarry locality is most probably the early descendant form of Algerina algena from the lower Gorstian, Ludlow of Algeria. Stage II, preserved in umbonal part of adult shell, is subcircular in outline, moderately inflated, inequilateral, and slightly opisthocline. Beaks prosogyrate. Outer surface formed by regularly spaced convex growth bands and furrows. Stage III developed as swollen band, which is separated from the adult valve by a distinct bend. Outer surface sculpture smooth, shell becomes more opisthocline. Adult shell (Stage IV) is broadly elliptical, obese $(\mathrm{H} / \mathrm{W}=1.35)$, inequilateral, opisthocline, enantiomorphous, inclined to the left. Bulky, prosogyrate and coiled umbo is slightly shifted to posterior. Anterior slope of the valve with frontal face is steeper than posterior slope. Widely lanceolate, slightly inflated frontal face is separated from the central part of the shell by a distinct bend, slightly curved anteriorly. Posterior part with wing-like shape, separated from the central part of the shell by a shallow radial sulcus. Outer surface sculpture is formed by the combination of growth wrinkles and anteriorly curved, prominent, narrow, radial ribs (in adult specimen more than 23 on frontal face, 40 in central part of the valve, and 8 on the wing). The ribs are not so distinct on the frontal face. Radial ribs and radial gutters equal in width, and are broadening ventrally. Inner surface sculpture is generally smoother. Shell thickness is $0.14 \mathrm{~mm}$. Other features are unknown.

Algerina aff. algena differs from Algerina algena by its longer shell, by the absence of radial ribs in the Stages II and III, and by the frontal face separated by distinct bend in adult stage. Number of radial ribs is practically the same except the higher number of radial ribs (8) on the wing (in Algerina algena 2-4 ribs). Algerina cocco (Kř̌́ž, 1999) from the lower Ludlow of the Carnic Alps, Italy is close to Algerina aff. algena in the development of the frontal face, but it differs by the more numerous radial ribs in adult shell.

\section{Dimensions. -}

$\begin{array}{lrrrr}\text { specimen } & \text { V } & \text { L } & \text { H } & \text { W/2 } \\ \text { JK } 11818 & \mathrm{~L} & 13.4 & 13.8 & 5.1\end{array}$

Mode of life. - Most probably reclining, byssate.

Occurrence. - Algerina algena Kř̌žz, 2008 is known from the cephalopod limestone biofacies of Algeria, northern margin of the western Hoggar Mountains, Ahnet Massif, Foum Belrem Section, and Ougarta Range, Saoura area, Oued Ali Section.

\section{Genus Tetinka Barrande, 1881}

Type species. - Tetinka sagitta Barrande, 1881, Bohemia, Prague Basin, Ludlow, late Ludfordian.

\section{Tetinka costulifera sp. nov.} Figure 3Z-ZE

Holotype. - The shell with conjoined valves, JK 11571, figured on Fig. 3Z-ZE.

Derivation of name. - Derived from Latin costula, rib, feminine diminutive, and from Latin suffix -fera, meaning carry, bear, have.

Type locality. - Bohemia, Karlštejn, Liščí Quarry near Amerika gamekeeper's lodge.

Type horizon. - Silurian, Ludlow, lower Gorstian, Kopanina Formation, section No. 942/2.

Material. - Holotype only.

Diagnosis. - Spanilidae with small dorso-ventrally elongated shell, inequivalve, narowly obovate, inflated, and enantiomorphous, distinctly inclined to the right, with flat, and lanceolate frontal face. 31 radial ribs developed in posterior part of the shell. On the anterior face of the shell are developed more than 26 radial ribs. Posterior wing is separated from the rest of the shell by shallow radial sinus. During ontogeny the shell becomes dorsoventrally elongated with length and width almost equal.

Description. - Small, inequivalve, inequilateral, dorsoventrally elongated $(\mathrm{H} / \mathrm{L}=1.5)$, narrowly obovate, and inflated shells $(\mathrm{L} / \mathrm{W}=1.2)$. The left valve is prosocline and the right valve is opisthocline. Enantiomorphous, distinctly inclined to the right. In the left valve overhanging, almost flat, lanceolate frontal face is separated from the posterior part of the shell by blunt edge, slightly curved anteriorly. The frontal face in the right valve is flat and wider than in the left valve; posterior slope in the right valve is steeper than frontal face. Prominent blunt umbones are in anterior terminal position, prosogyrate. Posterior wing is relatively narrow and separated by shallow radial sulcus from the rest of the valve. Outer surface is with numerous radial ribs ( $>26$ on the frontal 
face, 31 in posterior part of the shell) in combination with irregular growth wrinkles and inexpressive growth bands. On the posterior wing up to 6 radial ribs are visible. Both, the radial ribs and radial gutters broaden ventrally. External opisthodetic ligament is developed in short longitudinal groove.

\section{Dimensions. -}

$\begin{array}{lrrr}\text { specimen } & \text { L } & \text { H } & \text { W } \\ \text { JK } 11571 & 6.1 & 9.3 & 4.9\end{array}$

Remarks. - Tetinka costulifera sp. nov. from the lower Gorstian of the Prague Basin is the oldest known representative of the genus. It is most probably ancestral form of Tetinka caesarea (Barrande, 1881) from the middle Ludfordian cephalopod limestone biofacies. Shells of Tetinka caesarea are much larger $(\mathrm{H} \geq 20)$, dorso-ventrally elongated, inflated, enantiomorphous, inclined to the right. Frontal face is moderately inflated, lanceolate, separated from the posterior part of the shell by blunt edge slightly curved anteriorly. Prominent blunt umbones in anterior terminal position, prosogyrate. Posterior wing is dorsoventrally more elongated, protruding slightly posteriorly, well separated from the rest of the shell by wide radial sinus. Outer surface sculpture consits of numerous, not so distinct radial ribs and radial gutters in combination with irregular growth wrinkles. and narrow regularly spaced indistinct growth bands. The radial ribs are more developed on inner surface of the shell. The ratio of the width of radial ribs to that of radial gutters is $1: 1$. Both, the radial ribs and radial gutters broaden ventrally.

Mode of life. - Infaunal, byssate.

Superorder Pteriomorphia Beurlen, 1944

Order Cyrtodontida Cope, 1996

Superfamily Cyrtodontoidea Ulrich, 1894

Family Cyrtodontidae Ulrich, 1894

\section{Genus Macrodesma Isberg, 1934}

Type species. - Macrodesma striata Isberg, 1934, Sweden, Dalarna, Upper Ordovician.

Remarks. - Upper Ordovician Macrodesma from Dalarna, Sweden was considered by Newell (1969) to be younger synonym of the Upper Devonian Ptychodesma Hall \& Whitfield, 1872. For the type species of Ptychodesma Ptychodesma knappianum Hall \& Whitfield, 1872 very short anterior part curving downward into the ventral margin is very characteristic. In the type species of Macrodesma-Macrodesma striata Isberg, 1934 a lobate, evenly rounded, anterior margin is developed.

\section{Macrodesma enigma sp. nov.} Figure 4A-N

Holotype. - The left valve with most of the outer surface sculpture and posterior part of the ligament area preserved, JK 11761, figured on Fig. 4G-J.

Paratypes. - JK 11755-JK 11760, JK 11819, JK 11820, JK 11858, JK 11861-JK 11866 measured for dimensions, included into community analysis and figured on Fig. 4A-F, K-N.

Derivation of name. - From Latin aenigma, something mystery, obscure, riddle.

Type locality. - Bohemia, Karlštejn, Liščí Quarry near Amerika gamekeeper's lodge.

Type horizon. - Silurian, Ludlow, lower Gorstian, Kopanina Formation, section No. 942/2.

Material. - Three shells with conjoined valves, eight left valves and five right valves.

Diagnosis. - Ludlovian Macrodesma with dorsal line more than half of shell length, with anterior part evenly rounded. Umbones are in a little than one half of the shell length from anterior.

Description. - Shell medium-sized $(\mathrm{L}=29.6, \mathrm{H}=24.5$, $\mathrm{W}=7.0$ ), equivalve, longitudinally widely ovoidal, elongate, inequilateral $(\mathrm{L} / \mathrm{H}=1.11-1.31)$, inflated $(\mathrm{H} / \mathrm{W}=$ 1.75-2.99). Umbones are in a little than one half of the shell length from anterior, beaks prosogyrate. Dorsal margin almost straight, more than half of the shell length long. Anterior part of the shell is shorter and smaller than posterior part, and evenly rounded. Ventral margin is long, convex, posterior margin is also evenly rounded. Posterior end of the dorsal margin is angular. Outer surface sculpture formed by regularly spaced flat, narrow growth bands and furrows. In the furrows are rarely preserved fine radial costae, interrupted by growth bands. Commissure lies within a single plane, no discernible byssal gape. Ligament is duplivincular, almost opisthodetic, low, long, with several chevron type grooves. On inner surface low triangular area is developed between the umbones and posteriorly. Shell thickness is $0.19-0.76 \mathrm{~mm}$.

$\begin{array}{llrrr}\begin{array}{l}\text { Dimensions. }- \\ \text { specimen }\end{array} & \text { V } & \text { L } & \text { H } & \text { W/2 } \\ \text { JK } 11756 & \text { R } & 7.7 & 6.2 & 1.3 \\ \text { JK } 11761 & \text { L } & 8.8 & 7.5 & 1.7 \\ \text { JK } 11865 & \text { R } & 9.2 & 7.0 & 1.7 \\ \text { JK } 11866 & \text { L } & 9.2 & 7.6 & 2.0\end{array}$




$\begin{array}{llrrr}\text { JK } 11863 & \text { R } & 9.4 & 8.2 & 1.4 \\ \text { JK } 11862 & \text { L } & 9.7 & 7.8 & 1.3 \\ \text { JK } 11820 & \mathrm{~A} & 12.1 & 10.6 & 2.8 \\ \text { JK } 11861 & \mathrm{~A} & 15.4 & 13.9 & 3.3 \\ \text { JK } 11862 & \mathrm{~L} & 16.0 & 12.5 & 2.7 \\ \text { JK } 11865 & \mathrm{R} & 16.0 & 13.2 & 3.0 \\ \text { JK } 11756 & \mathrm{R} & 17.1 & 14.4 & 3.3 \\ \text { JK } 11761 & \mathrm{~L} & 17.8 & 14.3 & 3.5 \\ \text { JK } 11755 & \mathrm{~A} & 23.6 & 21.1 & 6.0 \\ \text { JK } 11756 & \mathrm{R} & >27.7 & - & 6.4 \\ \text { JK } 11761 & \mathrm{~L} & 29.6 & 24.5 & 7.0\end{array}$

Discussion. - The Gorstian Macrodesma enigma sp. nov. differs from Macrodesma striata Isberg, 1934 from the Upper Ordovician of Dalarna, Sweden by generally larger shells, by evenly rounded anterior part of the shell, by outer surface sculpture formed by regularly spaced flat, narrow growth bands and furrows and by the fine radial costae preserved in the furrows, and interrupted by growth bands.

Mode of life. - Most probably infaunal, byssate.

Order Pterioida Newell, 1965

Superfamily Mytiloidea Rafinesque, 1815

Family Mytilidae Rafinesque, 1815

Subfamily Modiolinae Keen, 1958

\section{Phthonia Hall \& Whitfield, 1869}

Type species. - Cypricardites sectifrons Conrad, 1842, U.S.A., New York, Middle Devonian.

\section{Phthonia regularis (Barrande, 1881) \\ Figure 4O-Y}

1881 Modiolopsis regularis Barr.; Barrande, pl. 285, figs I/6-9.

Lectotype. - (SD - herein); Internal mould of the shell with conjoined valves, NM L 22 768, figured by Barrande (1881) on pl. 285 as fig. I/9.

Paralectotype. - Internal mould of the shell with conjoined valves, with partly preserved outer surface sculpture, from the Ludlow, upper Ludfordian, Praha-Lochkov, Bohemia, NM L 22 767, figured by Barrande (1881) on pl. 285 as figs I/6-8.

Type locality. - Bohemia, Dlouhá hora Hill near Beroun.

Type horizon. - Silurian, lower Ludfordian.
Material. - Four shells with conjoined valves from the locality Liščí Quarry and the Barrande's types.

Diagnosis. - Ludlovian Phthonia with well developed fine radial costellae dorsally of umbonal ridge and in the posterior part of the shell.

Description. - Shell small to medium size ( $\mathrm{L}=15.9-21.7$; $\mathrm{H}=9.3-12.3$ ), elongate elliptical, equivalved, inequilate$\mathrm{ral}$, and obese $(\mathrm{H} / \mathrm{W}=1.20-1.26)$. Lunule developed. Umbones sub-anterior, relatively large, beaks are prosogyrate. Umbonal ridge well defined, becoming obsolete before reaching post-inferior extremity. Dorsal margin long, about $55-64 \%$ the shell length. Anterior end is short, lobate, posterior end is subangular. Posterior margin is evenly round, ventral margin is long and almost parallel with dorsal margin, slightly convex. Anterior margin evenly rounded. Outer surface sculpture of ventral part of the shell is smooth, with irregular growth wrinkles or very little convex narrow growth bands. Radial costellae are developed in dorsal part of the shell, dorsally of umbonal ridge, and may be seen also in the posterior part of the shell in a very low angle strong light. Inner surface is smooth. Ligament is opisthodetic, in wide and deep groove bordered by narrow ligamental nymphs. Interior unknown. Shell very thin.

Dimensions. -

$\begin{array}{lrrr}\text { specimen } & \text { L } & \text { H } & \text { W } \\ \text { NM L 22767 } & 11.7 & 7.4 & 4.6 \\ \text { NM L 22768 } & 13.9 & 9.1 & 5.8 \\ \text { JK 11765 } & 15.9 & 9.3 & 7.4 \\ \text { JK 11813 } & 16.8 & 10.4 & 9.0 \\ \text { JK 11763 } & 21.7 & 12.3 & 10.2\end{array}$

Discussion. - Phthonia regularis (Barrande, 1881) from the Gorstian and Ludfordian (Ludlow), Prague Basin, Bohemia is surprisingly closely related to Phthonia cylindrica Hall, 1883 from the Middle Devonian (Hamilton Group) of New York, U.S.A., which differs in having more elongated shells with outer surface sculpture consisting of extremely fine radial striae, more conspicuous ventrally of the umbonal ridge. Type species Phthonia sectifrons (Conrad, 1842) is also more elongated than Phthonia regularis but radial costellae are developed on all parts of the shell; they are stronger on the umbonal ridge, and on the anterior end. Phthonia semiradiata (Hall, 1860) from the upper Ludlow, Arisaig, Nova Scotia, Canada has also elongate elliptical shells but with flattened dichotomized radiating striae developed only in the posterior slope.

Mode of life. - Infaunal, burrowing.

Occurrence. - Bohemia, type locality and Praha-Lochkov, upper Ludfordian, Ludlow. 
Superfamily Ambonychioidea Miller, 1877

Family Ambonychiidae Miller, 1877

\section{Genus Ambonychia Hall, 1847}

Type species. - Ambonychia radiata Hall, 1847, U.S.A., New York, Kentucky, Ohio, Upper Ordovician (Pojeta 1962).

\section{Ambonychia volitans (Barrande, 1881)}

Figures 4Z, 5A

1881 Mytilus volitans Barr.; Barrande, pl. 211, figs $\mathrm{V} / 1-3$.

Lectotype. - (SD, herein), the right valve with outer surface sculpture preserved, NM L 21 396, figured by Barrande (1881) on pl. 211, figs V/2, 3, re-figured here on Fig. 4Z.

Paralectotype. - The left valve with outer surface sculpture preserved, NM L 21 395, figured by Barrande (1881) on pl. 211, fig. V/1.

Type locality. - Bohemia, Dlouhá hora Hill near Beroun.

Type horizon. - Silurian, lower Ludfordian.

Material. - One right valve from the locality Liščí Quarry and the Barrande's types.

Diagnosis. - The upper Wenlock and Ludlow alate Ambonychia with numerous fine radial ribs and gutters.

Description. - Medium size $(\mathrm{L}=11.6-17.7 ; \mathrm{H}=16.1-23.8)$, mytiliform, equivalved, inequilateral, alate and obese shells $(\mathrm{L} / \mathrm{W}=1.32-1.5)$, lacking an anterior lobe. Umbones are in extreme terminal position, beaks prosogyrate. Anterior margin is convex, posterior part is with prominent posterior wing. Outer surface sculpture consists of growth wrinkles and numerous convex radial ribs. No byssal gape is developed. Ligament and hinge unknown. Shell wall is very thin, $0.05-0.1 \mathrm{~mm}$.
Dimensions. -

$\begin{array}{llrrr}\text { specimen } & \text { V } & \text { L } & \text { H } & \text { W/2 } \\ \text { JK } 11737 & \text { R } & 11.6 & 16.1 & 4.4 \\ \text { NM L 21396 } & \text { R } & 15.8 & 22.0 & 6.0 \\ \text { NM L 21395 } & \text { L } & 17.7 & 23.8 & 5.9\end{array}$

Discussion. - Closely related is Ambonychia rara (Barrande, 1881) from the upper Wenlock Barrande's localities Loděnice-Lužce and Tachlovice-Middle Mill Race with concave anterior margin and outer surface sculpture consisting of numerous but flat ribs in combination with irregular growth rugae or growth bands and furrows. Ambonychia carens (Barrande, 1881) from the upper Wenlock Loděnice-Bubovice locality and from the lower Ludfordian (Ludlow) Dlouhá hora Hill near Beroun is more dorsoventrally elongated and without distinct posterior wing.

Mode of life. - Epibyssate.

Occurrence. - Bohemia, type locality; Tachlovice, Middle Mill Race Section No. 713/4, 6, 10, upper Wenlock, lower Homerian.

\section{Genus Amphicoelia Hall, 1865}

Type species. - Amphicoelia leidyi Hall, 1865, U.S.A., Illinois, mid and late Silurian, Niagaran and Cayugan.

\section{Amphicoelia pojetana sp. nov. Figure 5B-K}

Holotype. - The right valve with ligament area and byssal sinus preserved, JK 11669, figured on Fig. 5B, C.

Paratypes. - JK 11670-JK 11697, measured for dimensions, included into community analysis and figured on Fig. 5D-K.

Derivation of name. - In honour of John Pojeta Jr. palaeontologist, expert in the Lower Paleozoic Bivalvia, from the U.S. Geological Survey, Washington, D.C., U.S.A.

Type locality. - Bohemia, Karlštejn, Liščí Quarry near Amerika gamekeeper's lodge.

Figure 4. A-N - Macrodesma enigma sp. nov.; A - left lateral view, JK 11759, paratype, $\times 3$; B - left lateral view, JK 11820, paratype, $\times 2.7$; C-F - articulated specimen, JK 11755, paratype; C - right view, $\times 1.4$; D - left view, $\times 1.4$; E - anterior view, $\times 1.4$; F - dorsal view, $\times 1.4$; G-J - left valve, JK 11761, holotype; $\mathrm{G}$ - detail of duplivincular ligament, $\times 6.25 ; \mathrm{H}-$ dorsal view, $\times 1.6 ; \mathrm{I}-$ lateral view, $\times 1.4 ; \mathrm{J}-$ detail of the outer surface sculpture, $\times 6.8$; K, L - left valve, JK 11819, paratype; K - detail of duplivincular ligament, $\times 10.5$; L - left lateral view, $\times 2.3$; M - detail of left lateral view, JK 11862, paratype, $\times 3.2 ; \mathrm{N}$ - dorso-lateral right view, JK 11756, paratype, $\times 2 . \bullet \mathrm{O}-\mathrm{Y}-$ Phthonia regularis $($ Barrande, 1881); O, P - articulated specimen, NM L 22768, lectotype; O - right view, $\times 2.4$; P - left view, $\times 2.4$; Q, U - articulated specimen, JK 11813; Q - detail of lunula, $\times 3.5$; U - dorsal view, $\times 2.4$; R-T - articulated specimen, JK 11765; R - left view, $\times 2.8 ; \mathrm{S}$ - right view, $\times 2.8 ; \mathrm{T}$ - dorsal view, $\times 3.2 ; \mathrm{V}-\mathrm{Y}-$ articulated specimen, JK 11763 ; V - dorsal view, $\times 2 ; \mathrm{X}$ - right view, $\times 1.85 ; \mathrm{Y}$ - detail of the outer surface sculpture in dorsal part of the right valve, $\times 6$. $\bullet \mathrm{Z}-$ Ambonychia volitans $($ Barrande, 1881), right lateral view, JK $11737, \times 4.5$. 


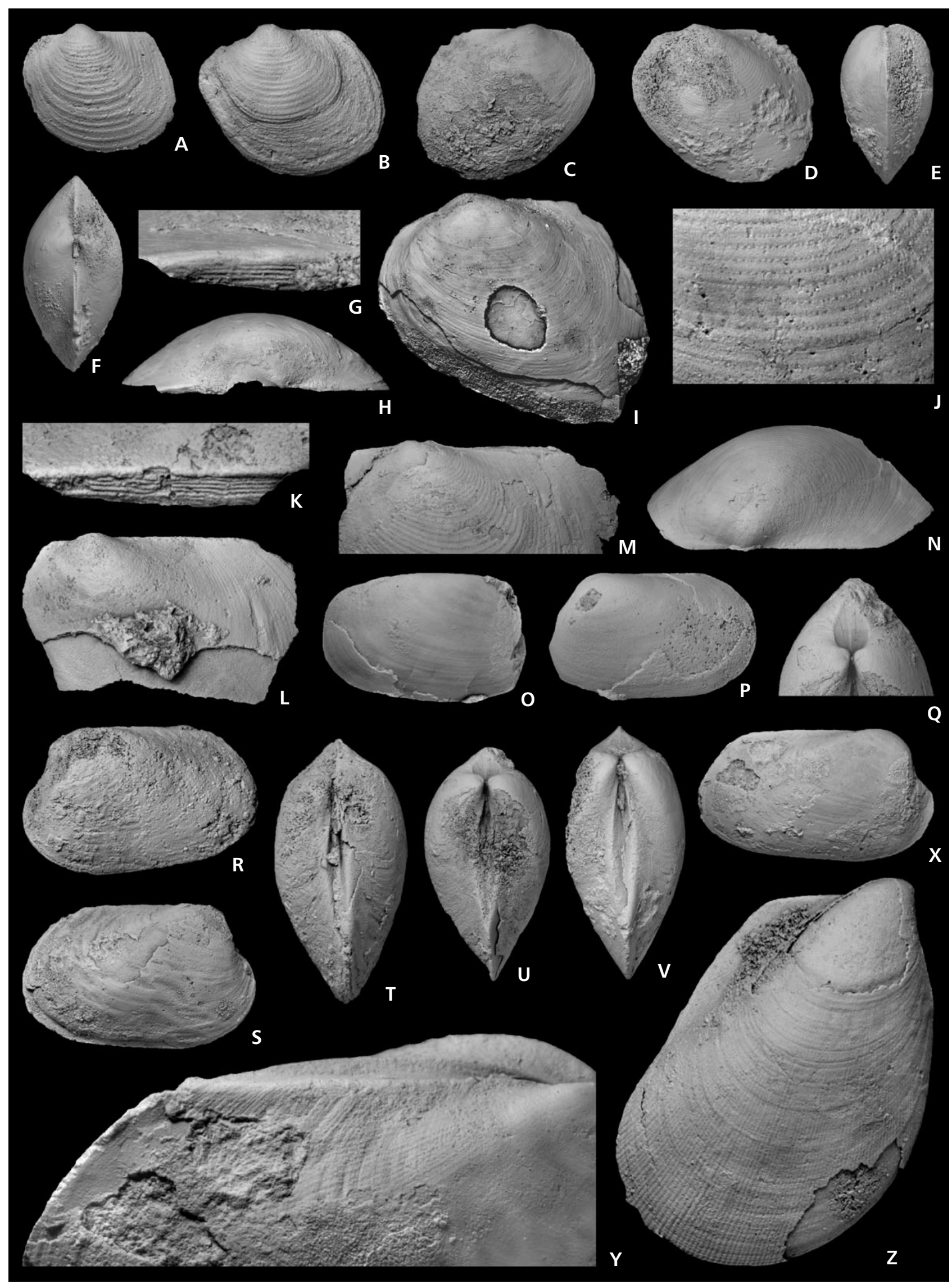


Type horizon. - Silurian, Ludlow, lower Gorstian, Kopanina Formation, section No. 942/2.

Material. - 14 left and 12 right valves.

Diagnosis. - Amphicoelia with numerous flat ribs and narrow radial gutters.

Description. - Medium ( $\mathrm{L} \geq 70.0 ; \mathrm{H} \geq 70.0$ ), equivalved, inequilateral, obese and prosocline shells $(\mathrm{L} / \mathrm{W}=1.77-2.18$, $\mathrm{H} / \mathrm{W}=1.33-2.25)$. Umbones are terminal, prosogyrate. Cardinal margin is long and straight. Anterior part relatively short, anterior margin convex, evenly rounded ventral and posterior margins. Posterior wing well developed. Outer surface sculpture formed by prominent numerous ribs convex in cross-section in combination with narrow radial gutters. Both the radial ribs and radial gutters broaden ventrally. Growth sculptures consists of growth wrinkles, irregularly distributed growth furrows and very low, weak growth bands. Commissure lies within a single plane, no discernible byssal gape. Shell relatively thin $(0.48-0.76 \mathrm{~mm})$. Byssal sinus prominent, developed right between umbones. Ligamental area with duplivincular grooves and ridges, transversally obliquely several times folded. No dentition.

$\begin{array}{llrrr}\begin{array}{l}\text { Dimensions. - } \\ \text { specimen }\end{array} & \text { V } & \mathrm{L} & \mathrm{H} & \mathrm{W} / 2 \\ \text { JK } 11680 & \mathrm{~L} & - & 28.7 & 10.8 \\ \text { JK } 11676 & \mathrm{~L} & 42.3 & >39.2 & - \\ \text { JK } 11674 & \mathrm{~L} & 62.0 & 64.0 & 14.2 \\ \text { JK } 11678 & \mathrm{R} & 63.6 & 55.5 & 18.0 \\ \text { JK } 11670 & \mathrm{~L} & >70.0 & >70.0 & 21.5\end{array}$

Discussion. - The ancestral species Amphicoelia fausta (Barrande, 1881) from the lower Homerian, Wenlock of the Prague Basin differs from Amphicoelia pojetana sp. nov. by the outer surface sculpture which consist of less numerous flat ribs with narrow radial gutters. Amphicoelia faustula (Barrande, 1881) is conspecific with $A$. fausta. Amphicoelia leidyi Hall, 1867 from the upper Wenlock, Racine Formation reef dolostone of Wisconsin and Illinois, North America (Watkins 1997) is closely related to Amphicoelia pojetana in its general shape but differs in its rounded anterior margin and less developed posterior wing.
Mode of life. - Most probably epibyssate.

\section{Genus Mytilarca Hall \& Whitfield, 1869}

Type species. - Inoceramus chemungensis Conrad, 1842, U.S.A., New York, Upper Devonian, Chemung Stage.

Remarks. - In the past, numerous Lower Paleozoic species classified under Mytilus Linné, 1758 and Mytilarca Hall \& Whitfield, 1869 (e.g., Barrande 1881, Isberg 1934, Pojeta 1966). The genus Mytilarca is known from the Upper Ordovician, Silurian and Devonian. In general, the specific classification is very difficult when only general mytiliform shape, outer and inner surface sculpture is known (Růžička \& Prantl 1961, Pojeta 1966). Since it is out of the scope of this paper to revise all the representatives of Mytilarca described in the past I compare my specimens found in lower Gorstian only with the upper Wenlockian and Ludlovian species described in the past from Bohemia (Barrande, 1881).

\section{Mytilarca parens (Barrande, 1881)}

Figure 5L-R

1881 Mytilus parens Barr.; Barrande, pl. 210, fig. II/1 (non pl. 210, figs II/2-13, and pl. 284, figs 22, 23).

Lectotype. - (SD, herein), the left valve with fragments of the shell preserved, NM L 21 385, figured by Barrande (1881) on pl. 210, figs II/1, re-figured here on Fig. 5M, R.

Paratypes. - Other Wenlockian specimens figured by Barrande under "Mytilus" parens are not from the type locality and have different or no outer surface preserved.

Type locality. - Bohemia, hills between Loděnice and Bubovice (Barrande 1881), Loděnice, Na Černidlech Hill.

Type horizon. - Silurian, Wenlock, lower Homerian, Motol Formation, grey-greenish tuffaceous limestone.

Material. - One shell with conjoined valves, 18 left, and four right valves.

Figure 5. A - Ambonychia volitans (Barrande, 1881), right lateral view, NM L 21396, lectotype, $\times 2.2 . \cdot \mathrm{B}-\mathrm{K}-$ Amphicoelia pojetana sp. nov.; B, C - right valve, JK 11669, holotype; B - detail of dorsal part, left lateral view of interior, $\times 2.3$; C - lateral view, $\times 2.7$; D, E - right valve, JK 11679 , paratype; D - lateral view, $\times 1.1$; E - detail of posterior wing, $\times 1.9 ; \mathrm{F}-\mathrm{H}$ - right valve, JK 11678, paratype; F - dorsal view, $\times 0.9 ; \mathrm{G}-$ lateral view, $\times 0.8 ; \mathrm{H}-$ anterior view, $\times 1.1$; I, K - left valve, JK 11670, paratype; I - detail of the outer surface sculpture, $\times 2.85 ; \mathrm{K}-$ lateral view, $\times 1.1 ; \mathrm{J}-$ left valve, JK 11680, paratype, detail of the outer surface sculpture, $\times 6.5$. $\bullet \mathrm{L}-\mathrm{R}-$ Mytilarca parens (Barrande, 1881); $\mathrm{L}-$ left lateral view, JK 11650 , $\times 1.3 ; \mathrm{M}, \mathrm{R}-$ left valve, NM L 21385, lectotype; $\mathrm{M}$ - lateral view, $\times 1.65 ; \mathrm{R}$ - detail of the outer surface sculpture, $\times 2.6 . \bullet \mathrm{N}-\mathrm{P}-$ articulated specimen, $\mathrm{JK} 11657 ; \mathrm{N}-$ dorsal view, $\times 2.5 ; \mathrm{O}-$ anterior view, $\times 1.9 ; \mathrm{P}-$ right view, $\times 2.4$; $\mathrm{Q}-$ left valve, detail of dorsal part with duplivincular ligament and hinge, JK 11666, × 6.2 . 


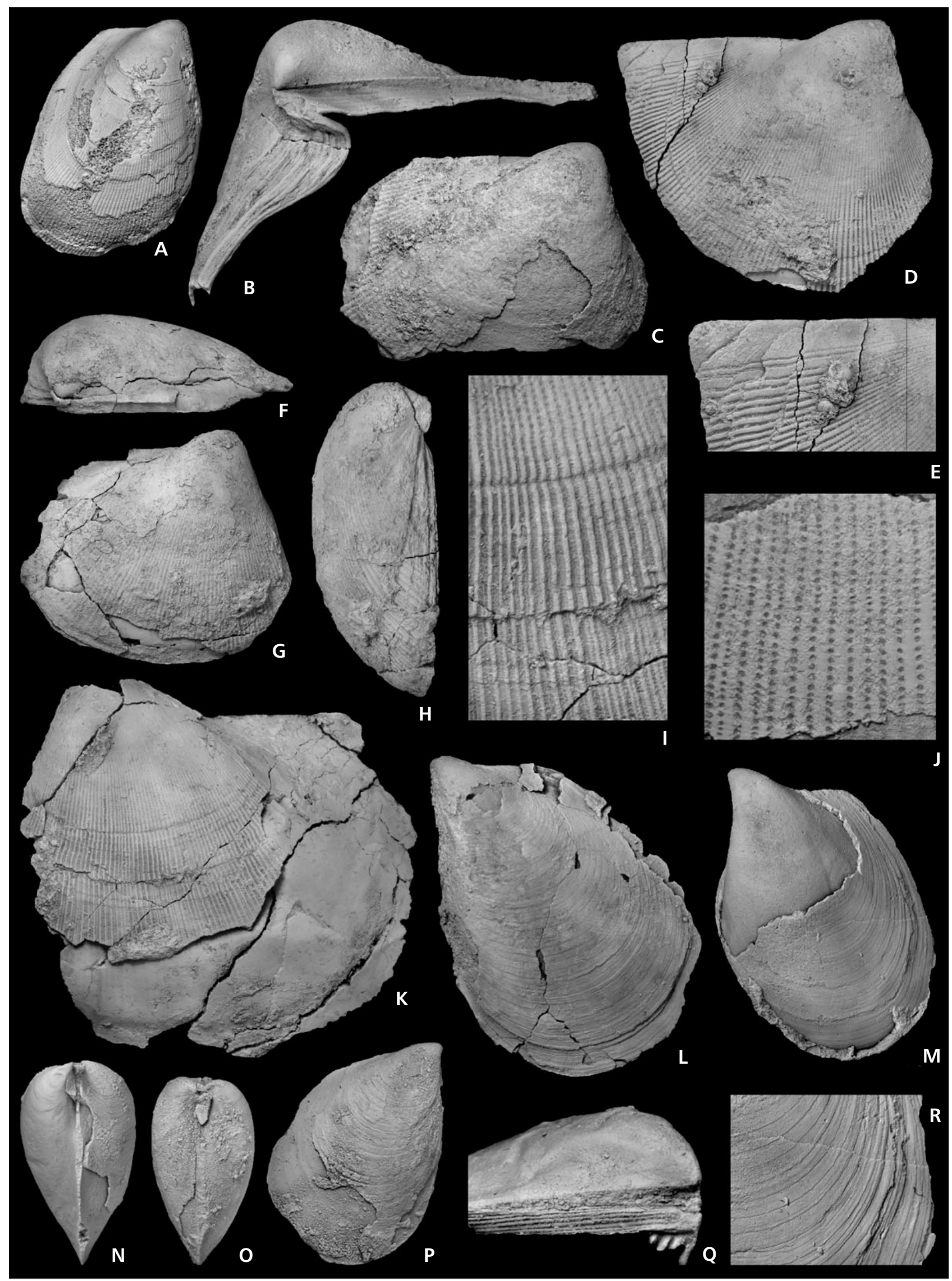


Diagnosis. - Upper Wenlock and lower Ludlow Mytilarca with regular flat and wide growth bands and narrow furrows.

Description. - Medium size $(\mathrm{L}=13.8-36.7 ; \mathrm{H}=15.6-45.5)$, mytiliform, equivalved, inequilateral, and obese shells lacking an anterior lobe. Umbones are in extreme terminal position, beaks prosogyrate. Outer surface sculpture consists of growth wrinkles and of regular flat and wide growth bands and narrow furrows. Byssal sinus weak, no byssal gape developed. Ligament external, ligament area with numerous fine duplivincular grooves and ridges. Hinge in the left valve is composed of at least three oblique cardinal teeth just behind umbo. Shell thickness is $0.13-0.5 \mathrm{~mm}$.

\section{Dimensions. -}

$\begin{array}{llrrr}\text { specimen } & \text { V } & \text { L } & \text { H } & \text { W/2 } \\ \text { JK } 11657 & \text { L } & 13.8 & 15.6 & 3.9 \\ \text { JK } 11652 & \text { L } & 20.1 & 24.2 & 6.2 \\ \text { JK } 11648 & \text { R } & 21.3 & 27.9 & 6.6 \\ \text { NM L } 21385 & \text { L } & 22.5 & 33.7 & 5.6 \\ \text { JK } 11650 & \text { L } & 36.7 & 45.5 & 8.6\end{array}$

Discussion. - The Wenlockian and Ludlovian species, described by Barrande (1881) as Mytilus faustulus, M. carens, $M$. rarus, and $M$. volitans have the mytiliform shells but their outer surface consists of radial ribs. They belong to Ambonychia Hall, 1847. In other Wenlockian mytiliform species described by Barrande (1881) such as Mytilus buridani, M. excisus and $M$. spatula the outer surface is not preserved.

Mode of life. - Epibyssate.

Occurrence. - Bohemia, type locality; Tachlovice, Middle Mill Race Section No. 713/4, 6, 10, upper Wenlock, lower Homerian.

\section{Mytilarca sp.}

Material. - 17 left, 26 right, mostly incomplete valves.

Discussion. - The Ludlow specimens assigned as Mytilarca sp. differ from Mytilarca parens (Barrande, 1881) by their outer surface sculpture consisting of irregular growth wrinkles only. Until there a modern revision of the genus Mytilarca, and the study of its evolution, and specific classification is impossible.

Mode of life. - Epibyssate.

Superfamily Pterioidea, Gray, 1847

Family Pterineidae, Miller, 1877

\section{Genus Molinicola Liljedahl, 1984}

Type species. - Molinicola gotlandica Liljedahl, 1984, Sweden, Gotland, Mölbos 1, Silurian, late Wenlock, Halla Beds.

\section{Molinicola bohemica sp. nov. Figure 6A-H}

Holotype. - The right valve with fragments of the shell preserved, JK 11560, figured on Fig. 6D, G.

Paratypes. - JK 11523-JK 11527, JK 11561-JK 11563 , JK 11868, JK 11980, measured for dimensions, included into community analysis, and figured on Fig. 6A-C, E, F.

Derivation of name. - Name derived from Bohemia.

Type locality. - Bohemia, Karlštejn, Liščí Quarry near Amerika gamekeeper's lodge.

Type horizon. - Silurian, Ludlow, lower Gorstian, Kopanina Formation, section No. 942/2.

Material. - 26 left and 15 right valves.

Diagnosis. - Molinicola with moderately inflated shells, left valve slightly more obese than the right valve, with outer surface sculpture composed only by growth wrinkles. Angle between the dorsal margin and the oblique anterior margin $71-80^{\circ}$.

Description. - Small to medium $(\mathrm{L}=13.4-29.3 ; \mathrm{H}=$ 9.4-21.9), antero-ventrally elongated, almost equivalved,

Figure 6. A-H - Molinicola bohemica sp. nov.; A-C - left valve, JK 11557, paratype; A - lateral view, detail of umbonal part, $\times 2.3$; B - lateral view, $\times 2.5$; C - detail of duplivincular ligament, $\times 11 ; \mathrm{D}, \mathrm{G}-$ right valve, JK 11560, holotype; D - lateral view, detail of umbonal part, $\times 4.2$; G - lateral view, $\times 3.3$; E, F - left valve, JK 11554, paratype; E - lateral view, $\times 2.3 ; \mathrm{F}$ - detail of the outer surface sculpture, $\times 7$. $\bullet \mathrm{H}-\mathrm{M}-$ Palaeopecten radvani sp. nov.; $\mathrm{H}$ - left valve, detail of umbonal part, JK 11705, paratype, $\times 1.85$; I - right valve interior, lateral view, JK 11710, paratype, $\times 2.4$; J, K - left valve, JK 11703, holotype; J - lateral view, $\times 1.5 ; \mathrm{K}$ - dorso-lateral view, detail of duplivincular ligament, $\times 2.7$; L - left lateral view, JK 11724 , paratype, $\times 1.2$; $\mathrm{M}$ - left valve, detail of posterior ear, JK 11735, paratype, $\times 1.4 . \cdot \mathrm{N}-\mathrm{Q}-$ Rhombopteria perunicola sp. nov.; $\mathrm{N}-$ left lateral view, JK 11518 , paratype, $\times 1.25$; O, P - left valve, JK 11517, holotype; O - lateral view, $\times 4.2$; P - detail of outer surface sculpture, $\times 7.75 ; \mathrm{Q}-$ right lateral view, JK 11522 , paratype, $\times 4.4$. 


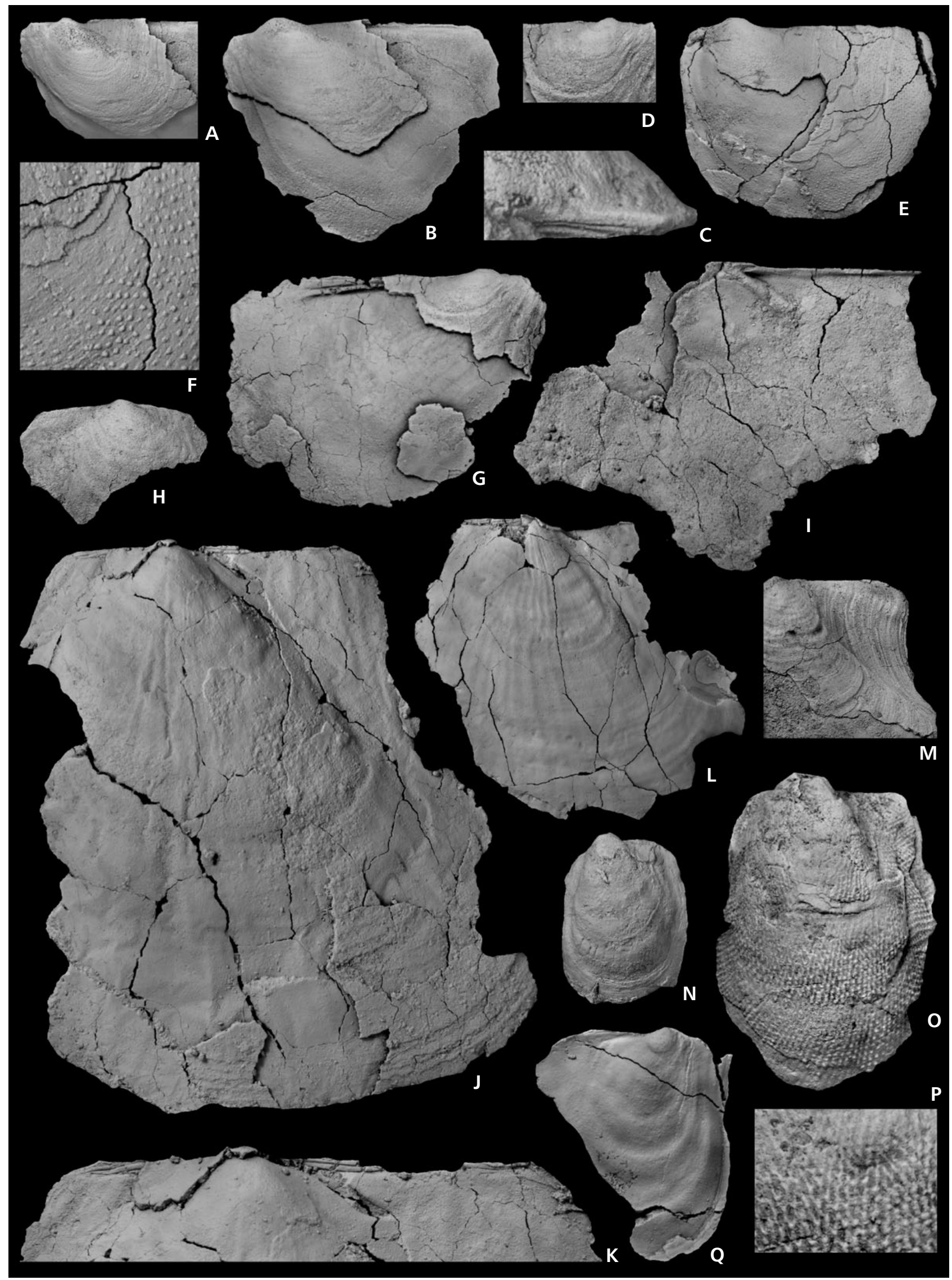


inequilateral, moderately inflated alate shell. The left valve is slightly more obese. Dorsal margin straight, forming maximum length of shell. Anterior extremity is with a small rounded ear or lobe, separated by very shallow sinus from evenly rounded ventral and posterior margins. Angle between the dorsal margin and the oblique anterior margin is $71-80^{\circ}$. Ventrally of anterior ear is a very small byssal opening. Posterior margin is slightly alate or almost perpendicular to the dorsal margin, terminates by blunt, rounded posterior extremity. Beaks prosogyrate, situated about $1 / 5$ th length from anterior margin. Commissure lies within a single plane. Outer surface sculpture of both vales consists of irregularly spaced growth wrinkles. In exceptionally preserved outer surface numerous small granulae developed on growth wrinkles are developed in adult parts of both valves (Fig. 6F). Large posterior adductor muscle scar is developed in the centre of the shell, and is connected with small anterior adductor muscle scar by narrow simple pallial line. Ligament duplivincular with ligament grooves preserved. Close to the posterior part of the hinge line, 2 lateral, parallel teeth are developed on the right valve. 1 lateral tooth is developed on the left valve and corresponds to a place between the lateral teeth on the right valve. Shell wall is $0.3-0.4 \mathrm{~mm}$ thick.

$\begin{array}{llrr}\begin{array}{l}\text { Dimensions. }- \\ \text { specimen }\end{array} & \text { V } & \text { L } & \text { H } \\ \text { JK } 11546 & \text { R } & 13.4 & >9.7 \\ \text { JK } 11527 & \mathrm{~L} & 13.6 & 10.0 \\ \text { JK } 11549 & \mathrm{~L} & 13.6 & 9.4 \\ \text { JK } 11544 & \mathrm{R} & 14.2 & >8.2 \\ \text { JK } 11560 & \mathrm{R} & 17.2 & 11.8 \\ \text { JK } 11558 & \mathrm{~L} & 17.2 & 12.9 \\ \text { JK } 11524 & \mathrm{~L} & 17.7 & 12.7 \\ \text { JK } 11557 & \mathrm{~L} & >18.2 & 14.9 \\ \text { JK } 11555 & \mathrm{R} & 20.2 & >11.8 \\ \text { JK } 11554 & \mathrm{~L} & >20.7 & 17.1 \\ \text { JK } 11562 & \mathrm{~L} & 21.0 & 14.5 \\ \text { JK } 11561 & \mathrm{R} & 21.9 & 14.6 \\ \text { JK } 11525 & \mathrm{~L} & 22.1 & 16.1 \\ \text { JK } 11556 & \mathrm{~L} & 22.5 & 16.6 \\ \text { JK } 11563 & \mathrm{~L} & 22.7 & 14.8 \\ \text { JK } 11542 & \mathrm{~L} & 23.0 & 16.9 \\ \text { JK } 11543 & \mathrm{R} & 25.8 & 17.0 \\ \text { JK } 11537 & \mathrm{R} & 26.4 & 17.7 \\ \text { JK } 11529 & \mathrm{~L} & 26.8 & >16.8 \\ \text { JK } 11541 & \mathrm{~L} & 29.3 & 21.9\end{array}$

Discussion. - Walmsley (1962) published a detailed study on Pteronitella retroflexa (Wahlenberg, 1821) from the upper Ludfordian of Gotland and compared it with the specimens of Pteronitella from the upper Ludfordian of the Welsh Borderland. He also compared Pteronitella retroflexa with the species described by Billings (1874) and
McLearn (1924) from the upper Wenlock, Ludlow and lower Př́idolí of Nova Scotia, Canada, which were later classified by Liljedahl (1984) as the new genus Molinicola. Liljedahl (1984) described from the upper Wenlock of Gotland new genus and new species Molinicola gotlandica Liljedahl, 1984 and compared it with Molinicola venusta (Billings, 1874), Molinicola oblonga (Billings, 1874), and Molinicola curta (Billings, 1874) from the upper Silurian of Nova Scotia. Molinicola bohemica sp. nov. differs from all these species by the angle between the dorsal margin and the anterior margin $71-80^{\circ}$ which is larger than in Molinicola gotlandica (50-60 $)$ and smaller than in Molinicola oblonga $\left(85-90^{\circ}\right)$, and Molinicola curta $\left(85^{\circ}\right)$. Molinicola venusta differs by more distinct, longer anterior ear. Molinicola cometula (Barrande, 1881) from the upper Wenlock of the Prague Basin, Bohemia is most probably one of the ancestral forms of Molinicola bohemica sp. nov., and differs by its larger and longer anterior ear, generally larger shells, by the outer surface growth sculpture which consists of regular wide and flat growth furrows and narrow growth bands, and by the smaller angle between the dorsal margin and the oblique anterior margin $\left(60^{\circ}\right)$. Molinicola reniformis (Barrande, 1881), also from the upper Wenlock of the Prague Basin, Bohemia differs from Molinicola bohemica sp. nov. by higher shells and rounded posterior extremity.

Mode of life. - Most probably semi-infaunal, byssate.

Superfamily Pectinoidae Rafinesque, 1815

Family Leiopectinidae Krasilova, 1959

\section{Palaeopecten Williams, 1913}

Type species. - Palaeopecten cobscooki Williams, 1913, U.S.A., Maine, Edmunds Formation, upper Silurian.

\section{Palaeopecten radvani sp. nov. \\ Figure 6I-M}

Holotype. - The left valve with fragments of shell preserved, JK 11703 figured on Fig. 6J, K.

Paratypes. - JK 11704-JK 11717, JK 11719-JK 11722, JK 11724-JK 11732, measured for dimensions, included into community analysis, and figured on Fig. 6I, L, M.

Derivation of name. - In honour of Radvan Horný, palaeontologist, expert in the Lower Paleozoic gastropods, from the National Museum, Prague. We excavated together the "gastropod beds" in the lower Ludlow at the locality Liščí Quarry near Amerika gamekeeper's lodge before 1966. 
Type locality. - Bohemia, Karlštejn, Liščí Quarry near Amerika gamekeeper's lodge.

Type horizon. - Silurian, Ludlow, lower Gorstian, Kopanina Formation, section No. 942/2.

Material. - 24 left and six right valves from the type locality.

Diagnosis. - Dorso-ventrally elongated Palaeopecten with relatively large shells and irregular growth bands and furrows in combination with slightly more prominent, irregular wide radial ribs or folds and short auricular buttresses in the more convex left valve. Right valve flat or a little inflated, only with growth sculpture, and with short auricular buttresses.

Description. - Relatively large shell ( $\mathrm{L}=59-72 \mathrm{~mm}, \mathrm{H}=$ 51.2-64 mm), upright, prosocline, inequilateral, dorsoventrally elongated. Left valve gently convex $(\mathrm{L} / \mathrm{W}=$ 2.9-3.0), right valve flat or only a little inflated. Commissure lies within a single plane. Umbones are low, indistinct, beaks prosogyrate, in anterior third of the dorsal margin length. Umbonal angle is $90-100^{\circ}$. Dorsal margin straight, shorter than the length of the valve. Shallow auricular sulci, anterior auricle and larger posterior auricle or wing are merging into body of shell without interruption, byssal notch absent. Anterior end of the dorsal line is blunt. Anterior margin, ventral margin and posterior margin evenly rounded. Posterior end of dorsal margin is obliquely truncated. Early shell preserved in the umbonal part is antero-posteriorly elongated, with posterior wing and outer surface sculpture consisting of regular growth bands and furrows. Outer surface sculpture of adult shell consists of growth wrinkles. In the left valve wide, irregular flat growth bands and irregular relatively wide, obtuse radial ribs or folds and gutters, more prominent in anterior part are developed. Inner surface sculpture of the left valve is similar. In the right valve only growth wrinkles are developed, inner surface is smooth. Ligament duplivincular, area is low, triangular, with a few grooves and ridges parallel with hinge line. In both valves prominent short auricular buttresses are developed on the inner surface of the sides of umbo with angle of divergence about $120^{\circ}$. Shell wall is very thin $(0.5-0.9 \mathrm{~mm})$.

$\begin{array}{llrrr}\begin{array}{l}\text { Dimensions. - } \\ \text { specimen }\end{array} & \text { V } & \text { L } & \text { H } & \text { width/2 } \\ \text { JK } 11704 & \text { L } & 59.0 & 51.2 & 10.2 \\ \text { JK } 11717 & \text { L } & 62.4 & 61.8 & >8.2 \\ \text { JK } 11716 & \text { L } & 71.2 & >63.0 & >7.4 \\ \text { JK } 11703 & \text { L } & >72.0 & 64.0 & 12.5\end{array}$

Discussion. - Palaeopecten obsequens (Barrande, 1881) from the upper Wenlock of the Prague Basin, Bohemia dif- fers from Palaeopecten radvani sp. nov. by very small rounded anterior ear and larger, acute posterior wing. Palaeopecten correctus (Barrande, 1881) from the upper Wenlock of the Prague Basin differs by distinctly transversally elongated shells. Palaeopecten danbyi (McCoy, 1851) from the upper Ludlow of Westmoreland, Great Britain, and the Ludlow and Přídolí of Arisaig, Nova Scotia, Canada and Eastport Area, Maine, U.S.A. has transversely elongated, generally smaller shells with more prominent radial ribs. Palaeopecten cobscooki Williams, 1913 from the Ludlow, Edmunds Formation of the Eastport Area, Maine, U.S.A. differs especially by generally smaller shells ( $\mathrm{L}=53.5 \mathrm{~mm}, \mathrm{H}=52 \mathrm{~mm}$ ), angular anterior auricle and posterior wing. In general the anterior auricle is larger and umbonal angle $\left(<90^{\circ}\right)$ is smaller.

Mode of life. - Palaeopecten radvani sp. nov. was most probably semi-infaunal, byssate, with probably more convex left valve down. Weak, flat and wide radial ribs, more prominent in the anterior part of the shell, could have increase friction when bivalve was partly buried in the sediment. Right valve was flat or only a little inflated, but may have have been even concave like in Palaeopecten obsequens (Barrande, 1881) from Bohemia and in Palaeopecten transversalis Williams, 1913 from Maine, U.S.A.

\section{Palaeopecten sp.}

Material. - Four left valves.

Discussion. - Mostly incomplete specimens without the outer surface sculpture preserved are designated here as Palaeopecten sp. Since they cannot be classified specifically they were used only for statistical purposes.

Mode of life. - Semi-infaunal.

Family Rhombopteriidae Korobkov, 1960

\section{Genus Rhombopteria Jackson, 1890}

Type species. - Avicula mira Barrande, 1881, Bohemia, Prague Basin, Silurian, upper Ludlow.

\author{
Rhombopteria perunicola sp. nov. \\ Figures 6N-Q, 7A-G \\ Holotype. - The left valve with most of shell preserved, JK \\ 11517 figured on Fig. 6O, P.
}

Paratypes. - JK 8535, JK 11499-JK 11516, JK 11518-JK 
11519, JK 11521-JK 11522, JK 11816 measured for dimensions, included into community analysis, and figured on Figs 6N, Q and 7A-G.

Derivation of name. - Derived from Perunica - peri-Gondwanan terrane and Latin cola, inhabitant.

Type locality. - Bohemia, Karlštejn, Liščí Quarry near Amerika gamekeeper's lodge.

Type horizon. - Silurian, Ludlow, lower Gorstian, Kopanina Formation, section No. 942/2.

Material. - One shell with conjoined valves, 21 left and two right valves.

Diagnosis. - Dorso-ventrally elongated Rhombopteria.

Description. - Shell subrhombic to subovoid in outline, dorsoventrally elongated, inequivalved. Right valve is almost flat, inequilateral, moderately prosocline, umbo small with prosogyrate beak, auricular buttresses slightly developed anteriorly and posteriorly of umbo. Left valve is inequilateral, moderately prosocline to opisthocline, variably inflated $(\mathrm{L} / \mathrm{W}=1.79-2.83, \mathrm{H} / \mathrm{W}=2.20-3.7)$, with dorsal margin straight, auricular sulci absent, anterior and posterior auricles merging into body of shell without interruption. Umbo large, prosogyrate. Anterior auricle is relatively small, lobate. Posterior auricle larger, wing like. Antero-ventral, ventral and postero-ventral margins evenly rounded. Commissure lies within a single plane except in anterior margin where it is concave on the left valve and convex on the right valve. Anterior slope of the left valve is steeper than posterior slope. Outer surface sculpture consists of wide, flat growth bands in combination with two sets of fine radial costellae or papillae arranged in quincunx. Inner surface smooth with weak, wide growth band and furrows. Large posterior adductor muscle scar (Fig. 7D) connected by pallial line with smaller anterior adductor muscle scar developed close to the umbo (Fig. 7G), pedal retractor muscle scars developed on right valve close to dorsal margin (Fig. 7G). Ligament area low, ligament duplivincular, with ligament grooves inclined to hinge axis with bent beneath the umbo. Teeth in central part of the hinge most probably absent as in the representative of Rhombopteriidae mentioned and figured by Johnston (1991, p. 305, fig. 7C, D). Shell wall thickness is $0.3 \mathrm{~mm}$.

\section{Dimensions. -}

$\begin{array}{llrrr}\text { specimen } & \text { V } & \text { L } & \text { H } & \text { width/2 } \\ \text { JK } 11517 & \mathrm{~L} & 9.1 & 13.3 & 3.7 \\ \text { JK } 11499 & \mathrm{~L} & 10.8 & 15.2 & 4.9 \\ \text { JK } 11504 & \mathrm{~L} & 13.6 & >18.7 & 6.0 \\ \text { JK } 11520 & \mathrm{~L} & >16.0 & 20.9 & 5.0\end{array}$

$\begin{array}{llrrr}\text { JK } 11518 & \text { L } & 16.4 & 21.5 & 6.9 \\ \text { JK } 11505 & \text { L } & 17.0 & 20.7 & 5.6 \\ \text { JK } 11519 & \text { L } & >17.1 & 25.7 & 8.1 \\ \text { JK } 11515 & \text { L } & 17.2 & 22.4 & 7.5 \\ \text { JK } 11513 & \text { L } & 18.3 & >22.2 & >6.0 \\ \text { JK } 11501 & \text { L } & 18.3 & >22.4 & 10.2 \\ \text { JK } 11512 & \text { L } & 20.2 & 24.1 & 7.5\end{array}$

Discussion. - Rhombopteria mira (Barrande, 1881) differs from Rhombopteria perunicola sp. nov. by generally antero-postero-ventrally elongated and smaller shells, by distinctly longer dorsal margin, by the slightly inflated right valve, and by the less inflated left valve. Rhombopteria sp. nov., described from the upper Wenlock, Racine Formation reef dolostone of Wisconsin and Illinois, North America (Watkins 1997) is closely related to Rhomboptetria perunicola by general shape and especially by dorsoventrally elongated shells.

Mode of life. - Reclining. Rhombopteria perunicola sp. nov. most probably rested on the left convex valve with the flat upper valve as a lid on the lower valve. The commissure was most probably above substratum and was kept free of clogging by sediment.

Superfamily Modiomorphoidea Miller, 1877

Family Praeostreidae Kř́žz, 1966

\section{Genus Praeostrea Barrande, 1881}

Type species. - Praeostrea bohemica Barrande, 1881, Bohemia, Prague Basin, Dlouhá Hora Hill near Beroun, Ludlow, Ludlordian.

\section{Praeostrea bohemica Barrande, 1881}

Figure 7J

1881 Praeostrea bohemica Barr.; Barrande, p. 147, pl. 111, fig. 2.

1881 Praeostrea bohemica var. simplex Barr.; Barrande, p. 147 , pl. 111, figs 3,4 .

1966 Praeostrea bohemica Barrande. - Kříž, pp. 30, 31, pl. 1, figs 1-8 (for complete previous synonymy see this paper).

2006 Praeostrea bohemica Barrande. - Kříž, pp. 148, 149, fig. $1 \mathrm{E}-\mathrm{G}$.

Lectotype. - Right valve, deposited in the National $\mathrm{Mu}-$ seum, Prague, under No. L 6788.

Type locality. - Bohemia, Prague Basin, Dlouhá Hora Hill near Beroun. 
Type horizon. - Silurian, Ludlow, Ludfordian.

Material. - One left valve.

$\begin{array}{lrrr}\begin{array}{l}\text { Dimensions. - } \\ \text { specimen }\end{array} & \text { length } & \text { height } & \text { width/2 } \\ \text { JK 95 } & >18.5 & >15.5 & -\end{array}$

Discussion. - By the general shape, inner surfaces sculpture, and ontogeny the left valve (interior) from the Liščí Quarry locality is conspecific with type material from the Ludfrodian (Ludlow) of Bohemia.

Mode of life. - Praeostrea bohemica was most probably reclining on the right inflated valve and byssally attached to the substrate particles.

Occurrence. - Praeostrea bohemica occurs from the Wenlock, Homerian, Testograptus testis Biozone up to early Lochkovian (Devonian), Monograptus uniformis Biozone in Bohemia, Prague Basin. It is quite common in the Cardiola gibbosa Community of the lowermost Gorstian and from the uppermost Přídolí and lowermost Lochkovian (Lower Devonian). It is also known from the Ludfordian of Steinhorn in Kellervald and Alfredschacht near Giessen, Germany and from the lowermost Lochkovian, Austria, Carnic Alps, Cellon Section.

Family Butovicellidae Kř́iž, 1965

\section{Genus Butovicella Kříž, 1965}

Type species. - Cardiola migrans Barrande, 1881. Bohemia, Prague Basin, upper Wenlock and Ludlow.

\section{Butovicella migrans (Barrande, 1881)}

Figure $7 \mathrm{H}$, I

1881 Cardiola migrans Barr.; Barrande (partim), p. 268, pl. 183, figs I/12-15; pl. 184, figs I/1-12, figs II/1-4, figs III-V. Non: pl. 184, figs I/13-16 (= Butovicella mima Kř́̌ž, 1969) and pl. 184, figs II/5-16 (= Butovicella medea Kříž, 1969).

1999b Butovicella migrans Barrande. - Kř̌́ž, p. 303, 304, pl. 10, figs 24, 27 (for complete previous synonymy see this paper).

Lectotype. - (designated by Kříž 1965) Internal mould of a left valve, deposited in the National Museum, Prague under the number L 6116, and figured by Barrande (1881), pl. 184, figs $\mathrm{V} / 1-4$.
Type locality. - Bohemia, Prague Basin, Praha-Butovice, $\mathrm{Na}$ Břekvici Section.

Type horizon. - Silurian, Ludlow, lower Gorstian, Kopanina Formation, Colonograptus colonus Biozone (Neodiversograptus nilssoni Biozone).

Material. - One left valve and two right valves.

Dimensions. -

$\begin{array}{lllll}\text { specimen } & \mathrm{V} & \mathrm{L} & \mathrm{H} & \mathrm{W} / 2\end{array}$

$\begin{array}{lllll}\text { JK } 11564 & \mathrm{R} & 6.8 & 2.9 & 1.7\end{array}$

$\begin{array}{lllll}\text { JK } 142 \mathrm{a} & \mathrm{R} & 9.2 & 6.5 & 2.1\end{array}$

Discussion. - In its general shape, outer and inner surfaces sculpture, and ontogeny the specimen from the Liščí Quarry locality is conspecific with Barrande's type material from the Homerian (Wenlock) and the Gorstian (Ludlow), Bohemia.

Mode of life. - Epibyssate, attached to the firm substrate, most probably algae or to the clasts at the bottom.

Occurrence. - Butovicella migrans is a common cosmopolitan representative of the Butovicellidae. The species occurs in the Homerian (Wenlock) up to the Ludfordian (Ludlow) of Bohemia, Prague Basin. For the occurrences apart from Bohemia see Kř́ž (1969, 1996, 1999c) and Kř́̌ž \& Serpagli (1993).

Superfamily Modiolopsoidea Fischer, 1887 Family Modiomorphidae Miller, 1877

\section{Mimerodonta Liljedahl, 1994}

Type species. - Mimerodonta atlei Liljedahl, 1994, Sweden, Gotland, Ludfordian, Ludlow, Silurian.

\section{Mimerodonta phaseolus sp. nov.} Figure $7 \mathrm{~K}-\mathrm{P}$

Holotype. - Right valve with the hinge tooth and the part of the outer surface preserved, JK 11739, figured on Fig. 7M, N.

Paratypes. - JK 11740-JK 11753, JK 11815 measured for dimensions, included into community analysis, and figured on Figs 7K, L, O, P.

Derivation of name. - From Latin phaseolus, kidney-bean, masculine diminutive; indeclinable noun.

Type locality. - Bohemia, Karlštejn, Liščí Quarry near Amerika gamekeeper's lodge. 
Type horizon. - Silurian, Ludlow, lower Gorstian, Kopanina Formation, section No. 942/2.

Material. - One shell with conjoined valves, six left and nine right valves.

Diagnosis. - Elongated Mimerodonta with distinctly larger posterior part than anterior part.

Description. - Shell medium in size (maximum $\mathrm{L}=25.5$ ), diagonally modioliform, equivalve, inflated $(\mathrm{H} / \mathrm{W}=$ 1.73-2.2; $\mathrm{L} / \mathrm{W}=2.45-2.67)$, inequilateral, posterior part of the shell distinctly larger than anterior part, which is separated by radial, shallow sinus. Maximum width of the shell is in about one third of the shell length from anterior. Umbones are prominent, in anterior position, beaks small, apart, above the hinge line, prosogyrate. Dorsal margin line long, about one half of the shell length, slightly convex. Anterior margin is short, evenly rounded. Ventral margin is long, slightly concave. Posterior margin evenly rounded, long. Outer surface sculpture is composed of irregularly spaced growth wrinkles. Inner surface is smooth. Ligament is opisthodetic, in the ligament groove. Hinge line slightly convex; hinge in right valve with a single, blunt, elongated cardinal tooth arranged just bellow and posterior to beak. Well developed smaller, deeply impressed anterior and larger, less impressed posterior adductor muscle scars connected by the simple pallial line, running at some distance from the shell margin. Dorsally of the anterior adductor muscle scar is developed small, deeply impressed circular pedal retractor muscle scar. Shell thickness is $0.23-0.56$.

\section{Dimensions. -}

$\begin{array}{llrrr}\text { specimen } & \mathrm{V} & \mathrm{L} & \mathrm{H} & \mathrm{W} / 2 \\ \text { JK } 11815 & \mathrm{~L} & 17.7 & 17.7 & 3.7 \\ \text { JK } 11739 & \mathrm{R} & >19.7 & 15.3 & 4.0 \\ \text { JK } 11740 & \mathrm{R} & 21.1 & 17.8 & 4.2 \\ \text { JK } 11742 & \mathrm{~L} & 23.0 & 16.3 & 4.7 \\ \text { JK } 11741 & \mathrm{R} & 24.6 & 18.3 & 4.6 \\ \text { JK } 11752 & \mathrm{R} & 25.5 & 19.1 & 4.8\end{array}$

Discussion. - Most closely related to Bohemian species is Mimerodonta njordi Liljedahl, 1994 from the Gorstian Hemse Beds of Gotland. Mimerodonta phaseolus sp. nov. differs in its more elongated shells and by distinctly larger posterior part than anterior part. Mimerodonta atlei Liljedahl, 1994 from the Ludfordian Burgswik Beds of Gotland has shorter shells and relatively longer dorsal margin.

Mode of life. - Most probably semi-infaunal.

\section{Genus Janicula gen. nov.}

Type species. - Nucula? potens Barrande, 1881, upper Wenlock, lower Homerian, Loděnice, Na Černidlech Hill, Bohemia.

Derivation of name. - Derived from Jana, first name of my best friend, my wife and from the former Barrande's preliminary identification of the type species as the genus Nucula? Gender feminine.

Diagnosis. - Modiomorphid with the hinge composed in the left valve by single cardinal, prominent blunt tooth, elongated longitudinally, bellow and immediately posterior to the beak; in the right valve by smaller cardinal tooth, elongated longitudinally, developed immediately anterior to the beak, and of corresponding sockets in opposite valves. No hinge plate developed.

Description. - Shell quadrangular-subovate, equivalve, inequilateral, postero-ventrally elongated, and inflated. Umbones prominent, beaks small, prosogyrate, close together, slightly raised above the dorsal margin, situated in the anterior $1 / 5$ of the shell length. Antero-dorsal and anterior margins evenly rounded and continuing in the convex ventral margin terminating in the rounded obtuse postero-ventral angle. Posterior margin obliquely truncated, postero-dorsal end rounded. Dorsal margin is convex. Outer shell surface is with growth wrinkles and less prominent irregular narrow growth bands and furrows. Inner shell surface is smooth. Well developed smaller anterior and larger posterior adductor muscle scars connected by the simple pallial line, running at some distance from the shell margin. Dorsally close to the anterior and posterior adductor muscle scars are small pedal retractor muscle scars. External opisthodetic ligament is developed in

Figure 7. A-G - Rhombopteria perunicola sp. nov.; A, B - left valve, JK 11519, paratype; A - detail of duplivincular ligament, $\times 5.8$; B - lateral view, $\times 1.85$; C-E - left valve, JK 11816, paratype; C - detail of duplivincular ligament, $\times 7.75 ; \mathrm{D}-$ lateral view, $\times 3.1 ; \mathrm{E}-$ dorso-lateral view, $\times 3.2 ; \mathrm{F}, \mathrm{G}-$ right valve, JK 11521, paratype; F - lateral view, $\times 3.3 ; \mathrm{G}$ - dorso-lateral view, detail of umbonal part, anterior adductor muscle scar and posterior pedal retractor, $\times 6.25$. $• \mathrm{H}, \mathrm{I}-$ Butovicella migrans (Barrande, 1881); H - right lateral view, JK 142a, $\times 4.6$; I - left lateral view, JK 11564, × 6. • J - Praeostrea bohemica Barrande, 1881, left valve interior, JK 95, × 2.3. $• \mathrm{~K}-\mathrm{P}-$ Mimerodonta phaseolus sp. nov.; K, L, O - articulated specimen, JK 11740 , paratype; K - left view, $\times 2.2 ; \mathrm{L}-$ dorsal view, $\times 2.4 ; \mathrm{O}-$ right view, $\times 2.4 ; \mathrm{M}, \mathrm{N}-$ right valve, JK 11739 , holotype; $\mathrm{M}-$ detail of the hinge, dorsal view, $\times 9 ; \mathrm{N}-$ lateral view, $\times 2.6$; $\mathrm{P}$ - right lateral view, JK 11741, paratype, $\times 1.45$. $-\mathrm{Q}-\mathrm{Z}$ - Janicula potens (Barrande, 1881); Q-S - articulated specimen, JK 11581; Q - left view, $\times 3$; $\mathrm{R}$-righ view, $\times 3 ; \mathrm{S}-$ dorsal view, $\times 2.6 ; \mathrm{T}-\mathrm{X}$ - articulated specimen, JK $11583 ; \mathrm{T}-$ anterior view, $\times 3.4 ; \mathrm{U}-$ dorsal view, $\times 3 ; \mathrm{V}-\mathrm{left}$ view, $\times 2.15 ; \mathrm{X}-$ right view, $\times 2.15$; Y, Z - left valve, NM L 27215, holotype; Y - lateral view, detail of the anterior adductor muscle scar. $\times 4.25 ; \mathrm{Z}-1$ lateral view, $\times 2.05$. 


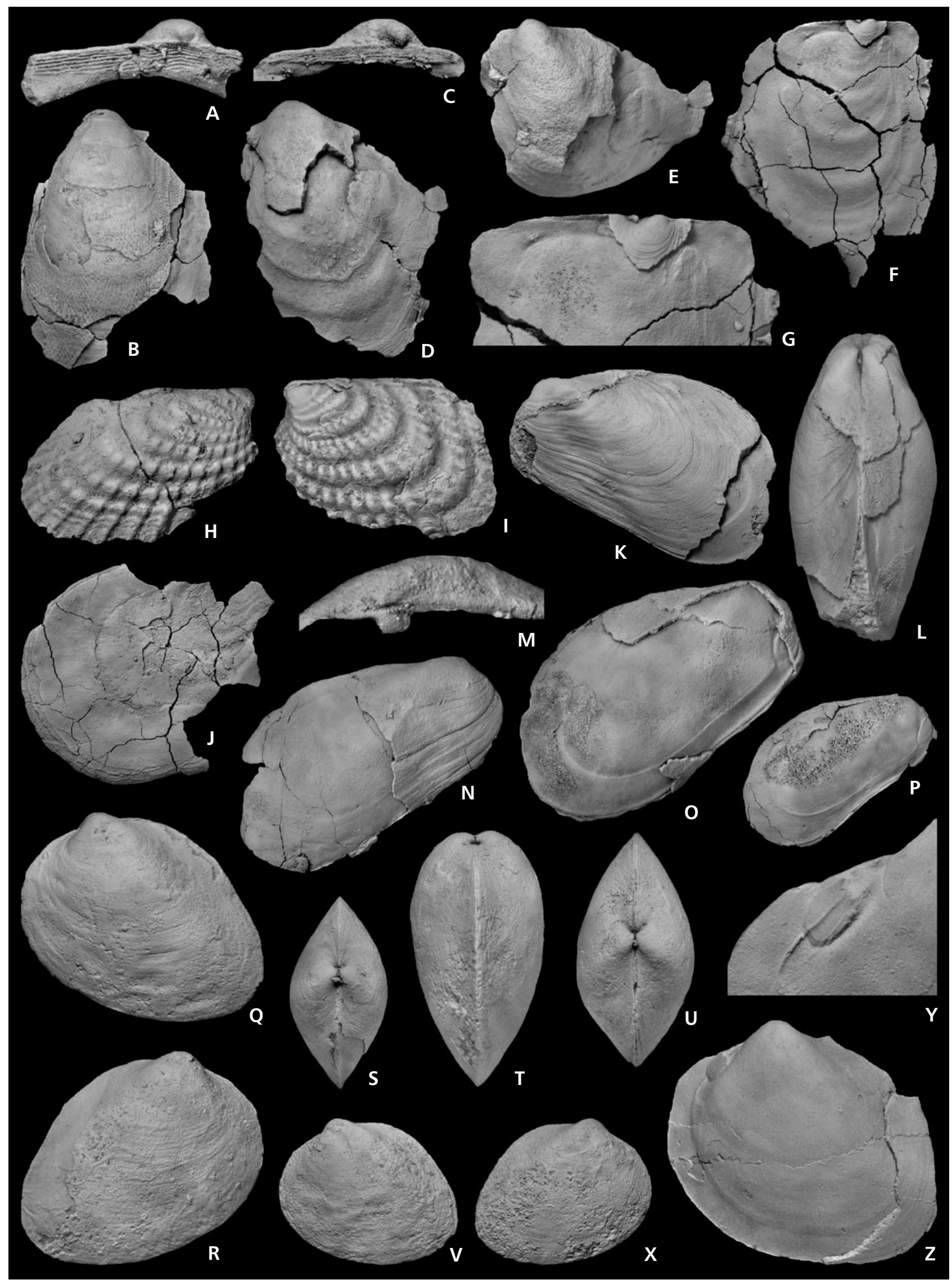


longitudinal groove. Hinge line slightly convex, hinge composed in the left valve of a single cardinal, robust blunt tooth bellow and immediately posterior to the beak, elongated in antero-posterior direction; a corresponding socket is developed in the right valve immediately posterior to the beak. A similar but smaller cardinal tooth is developed in the right valve, immediately anterior to the beak; a corresponding socket is developed immediately anterior to the beak in the left valve. No hinge plate.

Remarks. - Liljedahl (1994) erected the subfamily Modiomorphinae for 10 modiomorphid genera characterized by the presence of hinge teeth. Aleodonta Liljedahl, 1994, is characterized by hinge with no lateral teeth, one cardinal tooth in the right valve and corresponding socket in the left valve, Modiodonta Liljedahl, 1989 has hinge plate with one cardinal tooth in the right valve and corresponding socket in the left valve, no lateral teeth. The hinge of Modiomorpha Hall \& Whitfield, 1869 consists of a robust tooth in the left valve and no lateral hinge teeth. In Eurymyella Williams, 1912 a straight hinge line is without distinct teeth. Obscure thickening of the hinge is in some specimens developed under the beak of the right valve, with a broader thickening in the same position in the left valve. Linear thickening is developed near the posterior end of the hinge margin. In Colpomya Ulrich, 1895 the hinge of right valve consists of a cardinal tooth fitting into the depression of the left valve. Posteriorly and anteriorly of this depression is developed conspicuous strong process which is partly received in a shallow socket at the anterior side of the in the right valve (Liljedahl, 1994). Mimerodonta Liljedahl, 1994 lacks hinge plate and has one cardinal tooth and two shallow sockets in the right valve and one deep socket flanked by two tooth-like reinforcements in the left valve. Modiolodon Ulrich, 1895 has 1 to 3 oblique cardinal teeth in each valve. Callodonta Isberg, 1934 has hinge with 6 cardinal teeth, anterior one pointed and others blunt. Radiatodonta Dahmer, 1921 differs from other modiomorphids by several dorsally convergent hinge teeth.

In Goniophora Phillips, 1848 postero-ventrally elongated shells, diagonal carina or keel from umbo to the posteroventral extremity are characteristic, together with simple or multi-teeth complex hinge (Růžička \& Prantl 1959, Liljedahl 1984). On the other hand the presence of the keel or carina and simple or more complex hinge may be the result of the convergent evolution and different species now assigned to Goniophora may belong to several genera (Liljedahl 1984, p. 66). For all modiomorphids the dimyarian shells with simple pallial line are characteristic. All of them were infaunal or semi-infaunal byssate forms.

Janicula gen. nov. lacks the hinge plate and the hinge of the left valve is characterized by single, robust, cardinal blunt tooth, elongated longitudinally, bellow and immediately posterior to the beak (Fig. 8G-I). In the right valve the hinge is composed of smaller cardinal tooth, elongated longitudinally, immediately anterior to the beak (Fig. 8F). On both valves are developed corresponding sockets to the cardinal teeth; no lateral hinge teeth are developed.

Janicula gen. nov. is in general shape similar to the Permian genus Schizodus Murchison \& de Verneuil, 1844, which differs by schizodian hinge with short teeth and one pivotal tooth in the left valve, mostly not extended posteriorly and well developed hinge plate. According to Newell $\&$ Boyd (1975) the main tooth of the right valve is the anterior of the principal teeth of the two valves and is reinforced by an arcuate ridge reaching from the distal end of the tooth backward along the rim of the hiatus, terminating in a short bladelike posterior tooth. The left valve in most species possesses only two teeth.

The upper Silurian Schizodus? sp. from the Elwy Group, lower Ludlow, Saetograptus chimaera Biozone, of Wales described by Newell \& Boyd (1975) has probably also schizodian hinge with two cardinals in each valve at least and resembles Janicula gen. nov. by general shape. Somewhat similar is also Silurozodus Liljedahl, 1992, represented by the type species Silurozodus gotlandicus Liljedahl, 1992 from the upper Wenlock and upper Ludlow of Gotland, and classified as Schizodidae Newell \& Boyd, 1975. It differs from Janicula gen. nov. by small opisthogyre umbones, prominent umbonal ridge, complex pedal muscles pattern, and hinge, which consists in left valve of a weakly developed, small, narrow anterior marginal tooth, and a large triangular cardinal tooth; in right valve is developed narrow, shallow anterior socket, than medium sized, narrow cardinal tooth, large unfloored triangular socket and in posterior the lamellar tooth separated from the nymph by a shallow furrow. Schizodus sp. nov. (Watkins 1997) from the upper Wenlock, Racine Formation reef dolostone of Wisconsin and Illinois, North America has also a similar general shape to Janicula gen. nov.

There is a possibility that the family Schizodidae is ancestral to most of the trigoniacean families that have been morphologically and phyletically isolated from the modiomorphid genus Janicula gen. nov. in the early Silurian.

Species and distribution. - Janicula potens occurs in the lower Homerian, Wenlock and the lower Gorstian, Ludlow of the Prague Basin, Bohemia.

\section{Janicula potens (Barrande, 1881)}

Figures 7Q-Z, 8A-K

1881 Nucula? potens Barr.; Barrande, pl. 274, figs 13-15.

Holotype (by monotypy). - Internal mould of a left valve, NM L 27215, figured by Barrande, 1881 on pl. 274, figs $13-15$, and on Fig. 7Y, Z. 
Type locality. - Bohemia, hills between Loděnice and Bubovice (Barrande 1881), Loděnice, Na Černidlech Hill.

Type horizon. - Silurian, Wenlock, lower Homerian, Motol Formation, most probably Ischadites limestones.

Material. - 179 shells with conjoined valves, 422 left and 473 right valves.

Diagnosis. - See diagnosis of the genus.

Description. - Relatively small shell (maximal $\mathrm{L}=28.9$, $\mathrm{H}=22.1, \mathrm{~W}=12.2)$, quadrangular-subovate $(\mathrm{H} / \mathrm{L}=$ 0.71-0.92), equivalve, inequilateral, postero-ventrally elongated, and inflated $(\mathrm{L} / \mathrm{W}=1.96-2.58, \mathrm{H} / \mathrm{W}=$ 1.61-2.0). Umbones prominent, beaks small, prosogyrate, close together, slightly raised above the dorsal margin, situated in the anterior $1 / 5$ of the shell length. Antero-dorsal and anterior margins evenly rounded and continuing in the convex ventral margin terminating in the rounded obtuse postero-ventral angle. Posterior margin obliquely truncated, postero-dorsal angle rounded. Dorsal margin is convex. Outer shell surface is with growth wrinkles and less prominent irregular narrow growth bands and furrows. Inner shell surface is smooth. Elliptical smaller anterior and larger posterior adductor muscle scars connected by a simple pallial line, running at some distance from the shell margin. Dorsally close to the anterior and posterior adductor muscle scars are developed small elliptical pedal muscle scars. Longer longitudinal groove for external opisthodetic ligament is developed posteriorly of umbones. Hinge line is slightly convex, hinge lacks hinge plate and is composed in the left valve of a single cardinal, robust blunt tooth bellow and immediately posterior to the beak, elongated in antero-posterior direction; a corresponding socket is developed in the right valve immediately posterior to the beak. A similar but smaller cardinal tooth is developed in the right valve, immediately anterior to the beak; a corresponding socket is developed immediately anterior to the beak in the left valve. In some shells interior diagonal gill attachment ridge is developed (Fig. 8J). Shell thickness is $0.17-0.51 \mathrm{~mm}$.

$\begin{array}{lrrr}\begin{array}{l}\text { Dimensions. }- \\ \text { specimen }\end{array} & \mathrm{L} & \mathrm{H} & \text { width } \\ \text { JK } 11609 & 5.2 & 4.4 & 2.6 \\ \text { JK } 11608 & 5.2 & 5.2 & 3.2 \\ \text { JK } 11606 & 6.2 & 5.1 & 3.1 \\ \text { JK } 11607 & 6.3 & 5.0 & 3.1 \\ \text { JK } 11605 & 7.9 & 6.4 & 3.7 \\ \text { JK } 11613 & 8.5 & 6.9 & 3.9 \\ \text { JK } 11612 & 9.8 & 7.0 & 3.8 \\ \text { JK } 11594 & 10.3 & 8.8 & 5.0 \\ \text { JK } 11610 & 10.4 & 9.5 & 5.1\end{array}$

$\begin{array}{lrrr}\text { JK } 11604 & 10.7 & 8.7 & 4.8 \\ \text { JK } 11580 & 11.0 & 10.2 & 5.3 \\ \text { JK } 11602 & 11.2 & 9.4 & 5.1 \\ \text { JK } 11601 & 11.4 & 9.8 & 5.4 \\ \text { JK } 11593 & 12.8 & 11.3 & 6.3 \\ \text { JK } 11611 & 13.2 & 11.2 & 6.1 \\ \text { JK } 11584 & 13.4 & 11.0 & 5.5 \\ \text { JK } 11582 & 13.9 & 11.6 & 6.3 \\ \text { JK } 11581 & 14.2 & 13.2 & 7.1 \\ \text { JK } 11587 & 14.5 & 11.2 & 7.4 \\ \text { JK } 11583 & 15.0 & 12.5 & 7.0 \\ \text { JK } 11585 & 16.0 & 13.3 & 7.2 \\ \text { JK } 11592 & 16.6 & 12.6 & 7.0 \\ \text { JK } 11597 & 18.2 & 15.3 & - \\ \text { JK } 11599 & 18.8 & 15.7 & - \\ \text { JK } 11589 & 22.0 & 17.6 & 9.6 \\ \text { JK } 11600 & 22.1 & 18.3 & - \\ \text { JK } 11586 & 23.2 & 18.3 & 10.5 \\ \text { NM L } 27215 & 25.9 & 20.2 & - \\ \text { JK } 11588 & 27.7 & 20.5 & 12.2 \\ \text { JK } 11578 & 28.9 & 22.1 & - \\ \end{array}$

Discussion. - The same as for the genus.

Mode of life. - Infaunal, burrowing.

Occurrence. - Bohemia, type locality, lower Homerian, Wenlock, Liščí Quarry, Karlštejn, lower Gorstian, Ludlow.

\section{Genus Goniophora Phillips, 1848}

Type species. - Cypricardia cymbaeformis Sowerby in Murchison, 1839, England, upper Ludlow.

\section{Goniophora tyri Liljedahl, 1994}

Figures 8L-T, 9A-D

1994 Goniophora tyri n. sp.; Liljedahl, pp. 78, 79, figs 24, $53 \mathrm{~J}, \mathrm{O}$.

Holotype. - Internal mould of a right valve, RMMo 21682, deposited in the Swedish Museum of Natural History, and figured by Liljedahl (1994) on fig. 53J.

Type locality. - Sweden, Gotland, Linde Klint.

Type horizon. - Silurian, Ludlow, upper Gorstian, Hemse Beds.

Material. - Four shells with conjoined valves, 20 right and 23 left valves. 
Diagnosis. - Goniophora with transverse "finger print" sculpture.

Description. - Original description of Goniophora tyri Liljedahl, 1994 may be completed by description of the outer surface sculpture and the shell interior. Outer surface sculpture consists of transversely undulating finger-printlike ribs (Liljedahl 1994), which are almost perpendicular to the dorsal and ventral margins. On the anterior lobe separated from the rest of shell by radial sulcus, only rough growth wrinkles are developed. In the posterior part of the left and right valve is developed large, radially elongated posterior adductor muscle scar with short part of pallial line in ventral direction. Anterior reinforcing ridge is developed ventrally of a smaller, but deep, subcircular anterior adductor muscle scar.

Dimensions. -

$\begin{array}{llrrr}\text { specimen } & \mathrm{V} & \mathrm{L} & \mathrm{H} & \text { width/2 } \\ \text { JK } 11621 & \mathrm{~L} & 23.0 & 19.9 & 8.1 \\ \text { JK } 11623 & \mathrm{R} & >29.5 & >23.0 & 9.0 \\ \text { JK } 11618 & \mathrm{R} & >36.5 & >31.0 & 11.0 \\ \text { JK } 11627 & \mathrm{R} & >40.0 & >26.0 & 11.8 \\ \text { JK 11620 } & \mathrm{R} & >42.5 & >39.5 & 15.5 \\ \text { NM L 40 340 } & \mathrm{L} & 52.0 & 27.4 & 13.5\end{array}$

Discussion. - The Bohemian specimens are conspecific with the specimens described by Liljedahl (1994). They only differ in larger shells than specimens from Gotland.

Mode of life. - Most probably byssate, semi-infaunal with a carinas parallel to the sediment surface and anterior lobe dipped into the substrate (Liljedahl 1994).

Occurrence. - Sweden, Gotland, Hemse Beds, upper Gorstian, Ludlow.

\section{Goniophora ascia sp. nov.}

Figure 9E-P

Holotype. - Shell with conjoined valves with large fragments of the outer surface preserved, JK 11814 figured on Fig. 9E-I.
Paratypes. - JK 11821-JK 11834, measured for dimensions and figured on Fig. 9J-P.

Derivation of name. - From Latin ascia, ax, carpenter's adze.

Type locality. - Bohemia, Karlštejn, Liščí Quarry near Amerika gamekeeper's lodge.

Type horizon. - Silurian, Ludlow, lower Gorstian, Kopanina Formation, section No. 942/2.

Material. - Eight shells with conjoined valves, five left and six right valves.

Diagnosis. - The Ludlow Goniophora with outer surface sculpture composed of numerous, regularly spaced growth bands and furrows and with dorsal and ventral parts separated by prominent slightly S-shaped carina between the umbo and ventral extremity. The claw-like appearance of the proximal end of this ridge laterally is not developed.

Description. - Shell medium size $(\mathrm{L}=19.2, \mathrm{H}=30.9, \mathrm{~W}=$ 20.5), lanceolate, equivalve, strongly inequilateral, postero-ventrally elongated, and inflated $(\mathrm{H} / \mathrm{W}=$ 1.40-1.51). No byssal gape. Umbones prominent, in anterior third of the dorsal margin line, closely incurved, beaks prosogyrate. Each valve subdivided by slightly sinuous, prominent high and diagonal carina between umbo and postero-ventral extremity, with rounded crest. The carina represents an interesting structure. It is composed of interior transversal segments, corresponding by width approximately to the width of the growth band (Fig. 9N, O; JK 11830). Each segment has wide base, which sits probably on the very thin inner layer of the shell. Laterally the width decreases and in highest part of the umbonal ridge again increases. The top of the carina is rounded. When only the inner surface of the shell is preserved, in the place of carina only the flat ridge with growth bands corresponding to the carina interior segments is preserved. Hinge line relatively short, slightly curved, with external opisthodetic ligament groove where fragmentary remains of ligament may be seen (Fig. 9M, JK 11826). Anterior margin is lobate, ventral

Figure 8. A-K - Janicula potens (Barrande, 1881); A-C - articulated specimen, JK 11585; A - left view, $\times 2.2 ; \mathrm{B}-$ dorsal view, $\times 2.2$; C - right view, $\times 2.2 ; \mathrm{D}, \mathrm{E}-$ articulated specimen, JK 11588; D - left view, $\times 1.55 ; \mathrm{E}-$ dorsal view, $\times 2$; F - right valve, JK 11577, detail of the hinge, dorsal view, not whitened, $\times 7$; G - left valve, JK 11576 , detail of the hinge, dorsal view, $\times 10.5 ; \mathrm{H}-$ left valve, JK 11575 , detail of the hinge, dorsal view, $\times 6.75$; I - left valve, JK 11574, detail of the hinge, dorsal view, $\times 9.5$; J, K - left valve, JK 11597; J - lateral view, $\times 3.05$; K - detail of the posterior adductor muscle scar and posterior pedal retractor, $\times 6$. $\bullet$ L-T - Goniophora tyri Liljedahl, 1994; L, M - left valve, JK 11616; L - lateral view, $\times 2 ;$ M - dorsal view, posterior adductor muscle scar view, $\times 1.2 ; \bullet \mathrm{N}-\mathrm{P}, \mathrm{T}-$ right valve, JK $11623 ; \mathrm{N}-$ lateral view, $\times 2.15 ; \mathrm{O}-$ dorsal view, $\times 2.3 ; \mathrm{P}-$ detail of the anterior adductor muscle scar, $\times 3$; T - dorso-lateral view, detail of the broken off carina, $\times 5.4$; Q-S - articulated specimen, JK 11618; Q - right view, $\times 1.5$; $\mathrm{R}-$ dorsal view, $\times 0.8 ; \mathrm{S}-$ left view $\times 1.9$. 


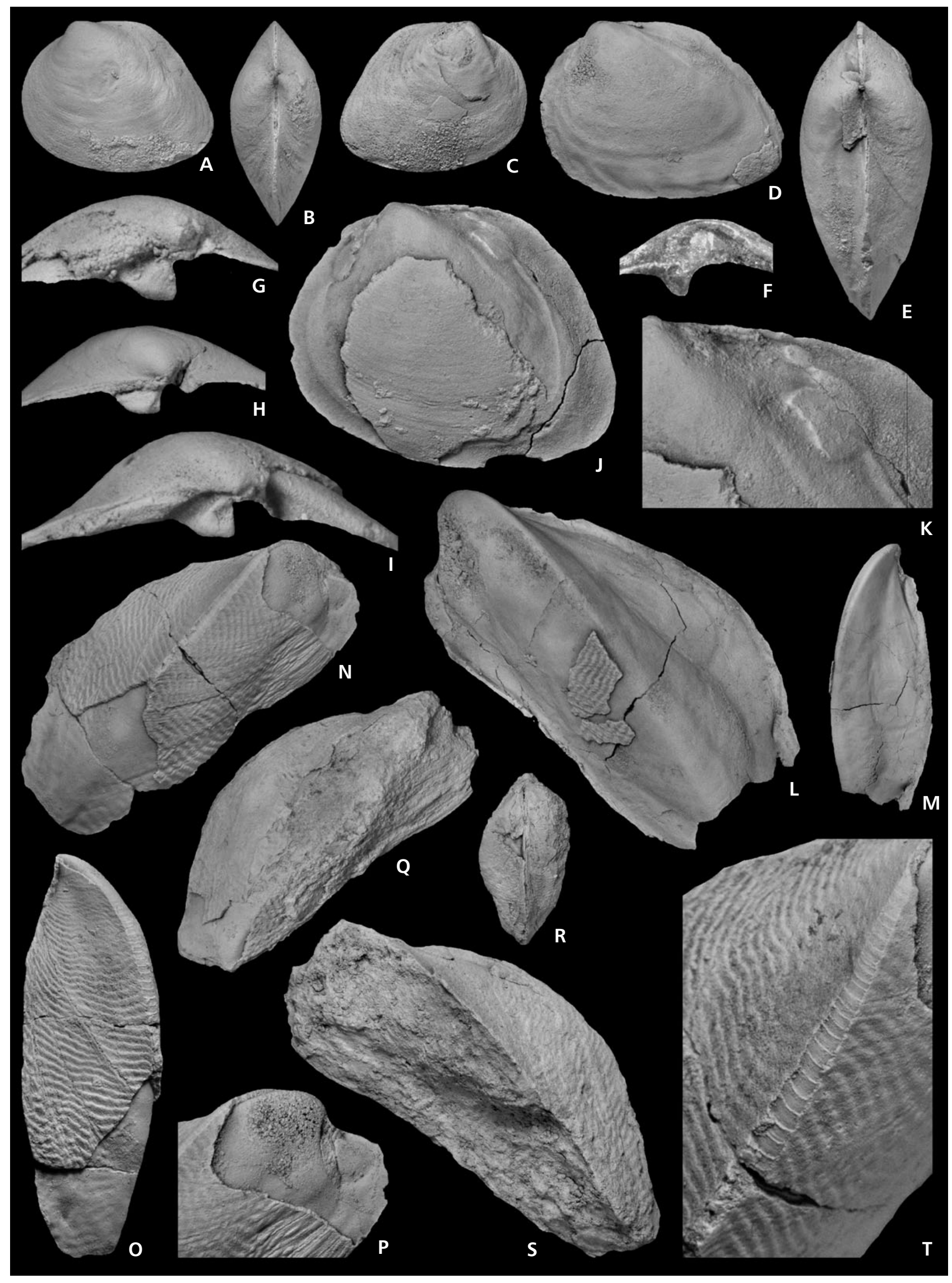


margin long, a little concave. Ventral extremity where diagonal ridge ends, is rounded. Posterior margin long, convex. Outer surface sculpture consists of numerous regularly spaced, rounded growth bands and furrows, crowded in ventral parts of adult shells. Inner surface sculpture consists also of numerous growth bands and furrows. Hinge unknown. Anterior and posterior reinforcement ridges well developed close to the hinge line, slightly curved (Fig. 9K). Anterior adductor muscle scar is elliptical, deeply impressed on the inner side of the anterior lobe. Other muscle scars and hinge not observed. Shell wall is $0.14-0.31 \mathrm{~mm}$ thick.

$\begin{array}{lrrr}\begin{array}{lrrr}\text { Dimensions. }- \\ \text { specimen }\end{array} & & & \\ \text { JK } 11814 & 14.9 & 21.9 & \text { W } \\ \text { JK } 11827 & 17.1 & 30.9 & 20.5 \\ \text { JK } 11823 & 19.2 & >25.0 & 16.4\end{array}$

Discussion. - Goniophora ascia sp. nov. is closely related to Goniophora onyx Liljedahl, 1984 from the upper Homerian (Wenlock), Halla Beds and the Gorstian (Ludlow), Hemse Beds of Gotland. It differs from the Bohemian species by presence of a claw-like appearance of the proximal end of the ridge between the umbo and ventral extremity. Goniopohora rara Barrande, 1881 from the upper Wenlock, Homerian of the Prague Basin has irregularly spaced wider growth bands, commonly diverging, differs by posteriorly elongated shells and by the presence of radial sinus in dorsal part of the shell separating prominent wing. On the inner surface of the wing is developed elliptical posterior adductor muscle scar. Goniophora compta sp. nov. and Goniophora solci sp. nov. differ by the presence of radial sculpture in outer surface. Goniophora secans Barrande, 1881 (Barrande 1881, pl. 255, figs II/1-3), from the reef Koněprusy Limestones, Pragian, Lower Devonian of the Prague Basin has similar outer surface sculpture but it differs by the very steep posterior part of the shell and subparallel dorsal and ventral margins.

Mode of life. - Most probably byssate, semi-infaunal with the carinas parallel to the sediment surface and anterior lobe dipped into the substrate (Liljedahl 1994).

\section{Goniophora compta sp. nov.} Figures 9Q-X, 10A-E

Holotype. - Slightly deformed shell with conjoined valves with large fragments of the outer surface preserved, JK 11838, figured on Fig. 9R, U-X.

Paratypes. - JK 11839-JK 11850, measured for dimensions and figured on Figs 9Q, S, 10A-E.

Derivation of name. - From Latin comptus, ornamented, adorned.

Type locality. - Bohemia, Karlštejn, Liščí Quarry near Amerika gamekeeper's lodge.

Type horizon. - Silurian, Ludlow, lower Gorstian, Kopanina Formation, section No. 942/2.

Material. - 16 shells with conjoined valves, 17 left, and 14 right valves.

Diagnosis. - The Ludlow Goniophora with long dorsal margin, narrowly elongated, and with outer surface sculpture composed of prominent numerous radial riblets in combination with numerous narrow growth bands and furrows.

Description. - Shell medium in size ( $\mathrm{L} \geq 34.3, \mathrm{H}=15.9, \mathrm{~W} \geq$ 22.5), lanceolate, equivalve, strongly inequilateral, posteroventrally narrowly elongated, and inflated $(\mathrm{H} / \mathrm{W} \geq$ $0.70-0.84)$. No byssal gape. Umbones prominent, in almost terminal anterior position, closely incurved, prosogyrate. Each valve subdivided by sinuous, prominent diagonal carina between umbo and postero-ventral extremity, with rounded crest. Dorsal margin line long, slightly convexly curved. Anterior margin is lobate, ventral margin long, concave. Its anterior part is almost parallel with the dorsal margin. Ventral extremity, where umbonal ridge ends, is rounded. Posterior margin relatively short, convex. Ventrally of the dorsal margin radial sulcus widening ventrally separates wing like development of the posterior part of the shell. Interior of the carina is composed of interior transversal segments, corresponding by width approximately to the width of the growth band (Fig. 9Q, JK 11849). Each segment has

Figure 9. A-D - Goniophora tyri Liljedahl, 1994; A, D - right valve, JK 11626; A - lateral view, $\times 2.1$; D - ventral view, detail of the outer surface sculpture, $\times 3.2$; B , C - right valve, JK 11627; B - dorso-lateral view, detail of the posterior reinforcement ridge, $\times 2.6 ; \mathrm{C}-\mathrm{ventral}$ part of the shell, outer surface sculpture, $\times 2.4$. $\bullet$ E-P - Goniophora ascia sp. nov.; E-I - articulated specimen, JK 11814, holotype; E - left view, $\times 2.1 ; \mathrm{F}-$ right view, $\times 2.75$; $\mathrm{G}$ - posterior view, $\times 1.4 ; \mathrm{H}-$ dorsal view, $\times 2.4 ; \mathrm{I}-$ anterior view, $\times 1.6 ; \mathrm{J}, \mathrm{K}-$ articulated specimen, JK 11823 , paratype; J - right view, $\times 2 ; \mathrm{K}-$ dorsal view, $\times 2.2 ; \mathrm{L}-$ left lateral view, JK 11828, paratype, $\times 3.3 ; \mathrm{M}-$ articulated specimen, dorsal view, JK 11826 paratype, $\times 2.2 ; \mathrm{N}, \mathrm{O}-$ right valve, JK 11830, paratype; $\mathrm{N}$-ventral view of the carina, $\times 4$; $\mathrm{O}$ - ventro-lateral view of the carina, $\times 5.5$; $\mathrm{P}$ - right valve, lateral view, detail of the broken off carina, JK 11833, paratype, $\times 3 . \bullet Q-X-$ Goniophora compta sp. nov.; Q - right valve, ventral view, detail of the carina, JK 11849 , paratype, $\times 4$; R, U-X - articulated specimen, JK 11838, holotype; $\mathrm{R}$ - dorsal view, $\times 1.1$; U - left view, $\times 2.1$; V - ventral view, $\times 1.5 ; \mathrm{X}-$ right view, $\times 2.1 ; \mathrm{S}, \mathrm{T}-$ right valve, JK 11839, paratype; $\mathrm{S}-$ lateral view, $\times 1.4 ; \mathrm{T}-$ detail of anterior adductor muscle scar, $\times 2.8$. 


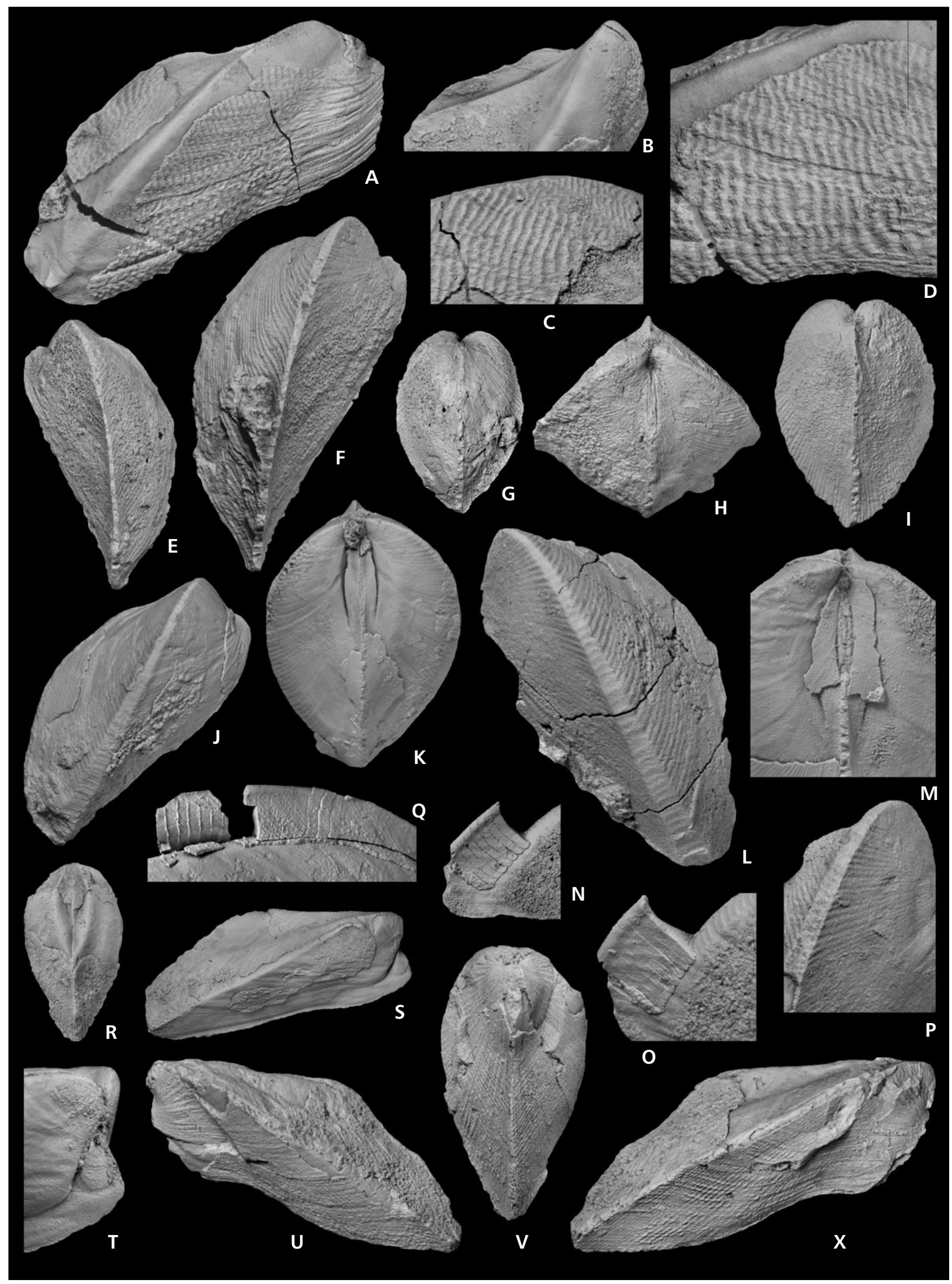


wide base, connected with the inner thin layer of the shell. Laterally the width decreases and in highest part of the umbonal ridge again increases. The top of the segment is rounded. The carina is covered by thin shell with radial riblets. Outer surface sculpture is composed of prominent numerous radial riblets in combination with growth wrinkles and numerous narrow growth bands and furrows. Inner surface sculpture almost smooth, sometime with faint radial ribs visible. Hinge unknown. Anterior and posterior reinforcement ridges well developed close to the dorsal margin. Anterior adductor muscle scar is elliptical, deeply impressed on the inner side of the anterior lobe. Other muscle scars and hinge not observed. Shell wall is $0.17-0.51 \mathrm{~mm}$ thick.

$\begin{array}{lrrr}\begin{array}{l}\text { Dimensions. }- \\ \text { specimen }\end{array} & & & \\ \text { JK 11850 } & 22.0 & \mathrm{H} & \mathrm{W} \\ \text { JK 11841 } & >29.7 & >14.6 & 12.1 \\ \text { JK 11838 } & 30.1 & 14.2 & 19.3 \\ \text { JK 11842 } & - & 15.4 & 18.3 \\ \text { JK 11839 } & >33.6 & 15.5 & 20.8 \\ \text { JK } 11840 & >34.3 & 15.9 & >22.5\end{array}$

Discussion. - The only similar species is Goniophora bellula Billings, 1874 from the upper Ludlow and Přídolí of Arisaig, Nova Scotia, Canada, which has radial ribs in outer surface sculpture and was the reason why McLearn (1918) designated it as the type species (genotype) of the new subgenus Goniophora (Cosmogoniophora) McLearn, 1918. Liljedahl (1994) pointed out that the outer surface sculpture without distinct change of the general shape and morphology may have only specific significance and considered this subgenus to be the synonym of Goniophora Philips, 1848. General shape of Goniophora compta with elongated shells and with long dorsal margin is similar to Goniophora acuta Lindström, 1880 from the Wenlock and Ludlow of Gotland and Scania. Goniophora compta differs from Goniophora acuta by the outer surface sculpture composed of the distinct radial riblets dorsally and ventrally of umbonal ridge.

Mode of life. - Most probably byssate, semi-infaunal with the carinas parallel to the sediment surface and anterior lobe dipped into the substrate (Liljedahl 1994).

\section{Goniophora solci sp. nov.}

Figure 10F-M

Holotype. - Incomplete left valve with the parts of shell wall with outer surface preserved, JK 11854, figured on Fig. 10I-L.

Paratypes. - JK 11851-JK 11853, measured for dimensions and figured on Fig. 10F-H, M.
Derivation of name. - In honour of Jiří Šolc and his father, amateur collectors from Praha-Nusle who introduced me to the localities in the vicinity of the Amerika gamekeeper's lodge and with whom I gained my first geological experiences in the Prague Basin in 1953-1957.

Type locality. - Bohemia, Karlštejn, Liščí Quarry near Amerika gamekeeper's lodge.

Type horizon. - Silurian, Ludlow, lower Gorstian, Kopanina Formation, section No. 942/2.

Material. - Four left and two right valves.

Diagnosis. - The Ludlow Goniophora with outer surface sculpture formed by narrow radial ribs and wide radial gutters on the ventral part of the shell and by the growth wrinkles and irregularly spaced narrow growth bands and furrows dorsally of the umbonal ridge.

Description. - Shell medium in size $(\mathrm{H}=14.3, \mathrm{~W}=16.6)$, lanceolate, equivalve, strongly inequilateral, elongated, and inflated $(\mathrm{H} / \mathrm{W}=0.80-0.86)$. No byssal gape. Umbones prominent, in almost terminal anterior position, closely incurved, prosogyrate. Each valve subdivided by sinuous, prominent carina between umbo and postero-ventral extremity, with carina broken off in all specimens, which I had at my disposal. Dorsal margin is relatively short, convex. Anterior part of the shell is lobate, separated from the shell by shallow radial sinus and by different outer surface sculpture formed by irregularly spaced growth bands and furrows. Ventral margin is slightly concave. Ventral extremity, where umbonal ridge ends, is rounded. Posterior margin relatively short, convex. Outer surface of the dorsal part of the shell is formed by growth wrinkles and irregularly spaced growth bands and furrows. Outer surface sculpture ventrally of the umbonal ridge is composed of the narrow radial ribs (10-11 in number) and wide radial gutters, broadening ventrally. Anterior lobe with growth sculptures is sharply separated by the last rib in the radial sinus. Inner surface sculpture of the dorsal part of the shell is almost smooth, on the ventral part radial ribs and gutters are developed. Anterior reinforcement ridge is not very deep, posterior reinforcement ridge is short and developed close to the dorsal margin. Anterior adductor muscle scar is widely ovoid, deeply impressed on the inner side of the anterior lobe. Other muscle scars and hinge not observed. Shell wall is $0.17-0.59 \mathrm{~mm}$ thick.

\section{Dimensions. -}

$\begin{array}{lllll}\text { specimen } & \mathrm{V} & \mathrm{L} & \mathrm{H} & \mathrm{W} / 2\end{array}$

$\begin{array}{lllll}\text { JK } 11851 & \mathrm{~L} & - & 10.2 & 6.3\end{array}$

$\begin{array}{lllll}\text { JK } 11854 & \text { L } & - & 12.6 & 7.6\end{array}$

$\begin{array}{lllll}\text { JK } 11853 & \mathrm{R} & - & 14.3 & 8.3\end{array}$ 
Discussion. - The Wenlockian and Ludlovian Goniophora acuta Lindström, 1880 from Gotland and Skåne has very similar outer surface sculpture but it differs from Goniophora solci sp. nov. by very antero-posteriorly elongated shells with almost subparallel dorsal and ventral margins and by distinctly larger ventral side of the shell (Liljedahl 1994). Goniophora media Barrande, 1881 from the upper Wenlock, Homerian of the Prague Basin has also similar but more elongated general shape, and different outer surface sculpture on the dorsal and ventral parts of the shell. Dorsally of the umbonal ridge the sculpture is composed of regularly spaced narrow growth bands and furrows and ventrally of the umbonal ridge are numerous narrow radial costellae. Goniophora aff. media from the Lochkovian, Lower Devonian of Podolia, Ukraine (Sinicyna 1964) differs from Goniophora solci especially by non lobate anterior part of the valve. Very similar in general shape and outer surface sculpture are Goniophora kokbaitalica Krasilova, 1963 from the upper Silurian and Goniophora strialis Krasilova, 1963 from the Lower Devonian of the north eastern Pribalchasie, Kazakhstan. They differ from probably ancestral Goniophora solci by distinct anterior lobate part of the shell separated by prominent ventral sinus and by narrow radial costellae in outer surface sculpture ventrally of umbonal ridge.

Mode of life. - Semi-infaunal with the carinas parallel to the sediment surface and anterior lobe dipped into the substrate (Liljedahl 1994).

\section{Goniophora sp.}

Material. - Two shells with conjoined valves, 35 left, and 22 right valves.

Discussion. - Mostly incomplete specimens without the outer surface sculpture preserved are designated here as Goniophora sp. Since they cannot be classified specifically they were used only for statistical purposes.

Mode of life. - Semi-infaunal.

Superordo Anomalodesmata Dall, 1889

Superfamily Pholadomyoidea Gray, 1847

Family Goniophorinidae Sánchez, 2006

\section{Genus Goniophorina Isberg, 1934}

Type species. - Goniophorina volvens Isberg, 1934, upper Ordovician, Boda Limestones, Dalarna, Sweden.

Remarks. - Isberg (1934) classified the toothless bivalves with distinct carina, and with the sub-parallel dorsal and ventral margins from the Upper Ordovician of Sweden as the genus Goniophorina. Liljedahl (1994) came to the opinion that "Goniophora-like" specimens with unknown hinge characters may belong to two or more different genera. He did not consider external sculpture and shell form to have generic significance and suggested that Isberg's genera Cosmogoniophora, Goniophorina, and Goniophorina (Cosmogoniophorina) to be synonyms of Goniophora. This opinion was not accepted by Cope (1996) who described Goniophora (Cosmogoniophora) extensa Cope, 1996 from the early Ordovician (Arenig) of South Wales, Great Britain. Subsequently Sánchez (2005) proposed for Goniophorina a new generic diagnosis including that dorsal and ventral margin may diverge posteriorly and that radial sculpture may be sometime presented. Sánchez (2006) discussed the systematic position and phylogenetic relationships of Goniophorina and included it in a new family Goniophorinidae, together with the genus Lossella Sánchez, 2006 from the late Tremadoc and early Arenig of Argentina. I agree with Sánchez (2006) that Goniophorinidae may be classified as the ancestral forms of the Anomalodesmata.

\section{Goniophorina nitidula sp. nov.}

Figures 10N-Z, 11A, B

Holotype. - Shell with conjoined valves and with large fragments of the outer surface preserved, JK 11766, figured on Fig. 10N-Q.

Paratypes. - JK 11767-JK 11786, JK 11791 measured for dimensions, included into community analysis, and figured on Figs 10R-Z, 11A, B.

Derivation of name. - From Latin nitidus, shining, neat, elegant.

Type locality. - Bohemia, Karlštejn, Liščí Quarry near Amerika gamekeeper's lodge.

Type horizon. - Silurian, Ludlow, lower Gorstian, Kopanina Formation, section No. 942/2.

Material. - 53 shells with conjoined valves, 131 left, 126 right valves from the type locality.

Diagnosis. - The Ludlow Goniophorina with fine radial costae.

Description. - Small lanceolate shells ( $\mathrm{L}=9.7-18.7, \mathrm{H}=$ 5.0-8.1) are subequivalve, strongly inequilateral, longitudinally elongated, inflated $(\mathrm{H} / \mathrm{W}=1.06-1.67)$. Umbones are prominent, in almost terminal anterior position, closely 
incurved, prosogyrate. Frequently the beaks are not exactly in opposition and one of them is slightly shifted anteriorly or posteriorly (Fig. 10P). Valves are subdivided by sinuous, prominent rounded diagonal umbonal ridge or almost carina between umbo and postero-ventral extremity. Dorsal margin is straight, less than the half and more than the third of the shell length. Dorsal and ventral margins are subparallel. Posterior end of the dorsal margin rounded. Posterior margin slightly convex; posterior extremity where the diagonal ridge meets the margin of the shell forms the sharp angle. Ventral margin is long, slightly convex. Anterior margin is evenly rounded. In front of the umbo small lunula is developed. Outer surface sculpture is formed of growth wrinkles and irregularly spaced narrow growth bands and furrows in combination with fine radial riblets and gutters. The radial sculpture is developed in uppermost shell layer of the shell only and it is preserved quite rarely since the uppermost shell layers were probably abraded away. Ligament is opisthodetic, in the distinct ligament groove. Rounded, relatively large posterior adductor muscle scar is developed between the posterior part of the dorsal margin and umbonal ridge. Posteriorly of the adductor muscle scar is visible short portion of the pallial line between the muscle scar and the umbonal ridge. The anterior adductor muscle scar is rarely deeply inserted on the anterior part of the shell. At the posterior end of narrow hinge area, at least one narrow lateral tooth is developed (Fig. 11B). Shell thickness is $0.1-0.17 \mathrm{~mm}$.

$\begin{array}{lrrr}\begin{array}{l}\text { Dimensions. }- \\ \text { specimen }\end{array} & & & \\ \text { JK } 11782 & 9.7 & 5.0 & \text { W } \\ \text { JK } 11771 & 11.6 & 5.5 & 5.2 \\ \text { JK } 11772 & 14.7 & 6.5 & 5.7 \\ \text { JK } 11769 & >15.2 & 7.5 & 6.4 \\ \text { JK } 11774 & 15.5 & 7.2 & 6.8 \\ \text { JK } 11776 & 16.2 & 7.6 & 6.8 \\ \text { JK } 11766 & >16.4 & 7.9 & 6.8 \\ \text { JK } 11767 & >16.9 & 9.0 & 7.2 \\ \text { JK } 11775 & 17.0 & 8.0 & 6.4 \\ \text { JK } 11777 & >17.0 & 7.8 & 6.9 \\ \text { JK } 11773 & 18.7 & 8.1 & 7.3\end{array}$

Discussion. - The lectotype (SD herein) of Goniophorina testis (Barrande, 1881) from the Homerian, Wenlock, locality Tachlovice, Middle Mill Race, Prague Basin, Bohemia, figured by Barrande (1881) on pl. 261 as figs 1-5 differs from Goniophorina nitidula in its generally larger shell and outer surface sculpture without radial costellae ventrally of umbonal ridge while dorsally of the ridge fine radial striae are developed. Goniophorina testis from the Lochkovian, Lower Devonian of Podolia, Ukraine (Sinicyna 1964) is very similar to the Barrande's lectotype in its size and outer surface sculpture without the radial riblets.

Mode of life. - Burrowing, infaunal (Sánchez 2006).

Family Grammysiidae Miller, 1877

\section{Cymatonota Ulrich, 1895}

Type species. - Cymatonota typicalis Ulrich, 1895, U.S.A., Ohio, Upper Ordovician.

\section{Cymatonota prolata sp. nov.} Figure 11C, D

Holotype. - Right valve with most of outer surface preserved, JK 11738, figured on Fig. 11C, D.

Derivation of name. - From Latin prolatus, extended, elongated.

Type locality. - Bohemia, Karlštejn, Liščí Quarry near Amerika gamekeeper's lodge.

Type horizon. - Silurian, Ludlow, lower Gorstian, Kopanina Formation, section No. 942/2.

Material. - One right valve.

Diagnosis. - The Ludlow Cymatonota with distinctly long shells.

Figure 10. A-E - Goniophora compta sp. nov.; A, C - articulated specimen, JK 11841, paratype; A - dorsal view of the outer surface sculpture, $\times 3.1$; C - ventral view, $\times 2.1$; B - left valve, ventral view, detail of the carina, JK 11846, paratype, $\times 4.4$; D - articulated specimen, ventral view, JK 11845 , paratype, $\times 4.5$; E - left lateral view, JK 11844, paratype, $\times 2.3$. $・ \mathrm{~F}-\mathrm{M}-$ Goniophora solci sp. nov; F, G - left valve, JK 11851, paratype; F - dorsal view, posterior reinforcement ridge, $\times 2.8 ; \mathrm{G}-$ ventro-lateral view, $\times 3 ; \mathrm{H}$ - right lateral view, JK 11853, paratype, $\times 1.7 ; \mathrm{I}-\mathrm{L}-$ left valve, JK 11854 , holotype; I - dorso-lateral view, $\times 2.8 ; \mathrm{J}$ - detail of anterior adductor muscle scar, $\times 3.25 ; \mathrm{K}$ - ventro-lateral view, detail of outer surface sculpture, $\times 3$; L - lateral view, $\times 2.1 ; \mathrm{M}$ - left valve, vento-lateral view, JK 11852, paratype, $\times 2 . \bullet \mathrm{N}-\mathrm{Z}-$ Goniophorina nitidula sp. nov.; N-Q - articulated specimen, JK 11766, holotype; $\mathrm{N}$ - right view, $\times 3.15$; O - left view, $2.95 ; \mathrm{P}-$ anterior view, $\times 3$; Q - dorsal view, $\times 2.1 ; \bullet \mathrm{R}$, U - articulated specimen, JK 11768 , paratype; $\mathrm{R}$ - dorsal view, $\times 1.65$; $\mathrm{U}$ - dorsal view, detail of the posterior adductor muscle scars with the pallial line, $\times 2.5 ; \bullet \mathrm{S}-$ articulated specimen, left view, JK 11767, paratype, $\times 3.3 ; \mathrm{T}$ - articulated specimen, left view, JK 11777, paratype, $\times 2.6 ; \mathrm{V}, \mathrm{X}-$ articulated specimen, JK 11769 , paratype; V - left lateral view, detail of the outer surface sculpture, $\times 5$; X - left view, $\times 4.1$; Y - left lateral view, detail of the carina, JK 11784 , paratype, $\times 7$; Z - articulated specimen, right ventro-lateral view, detail of the outer surface sculpture, JK 11772, paratype, $\times 6.5$. 


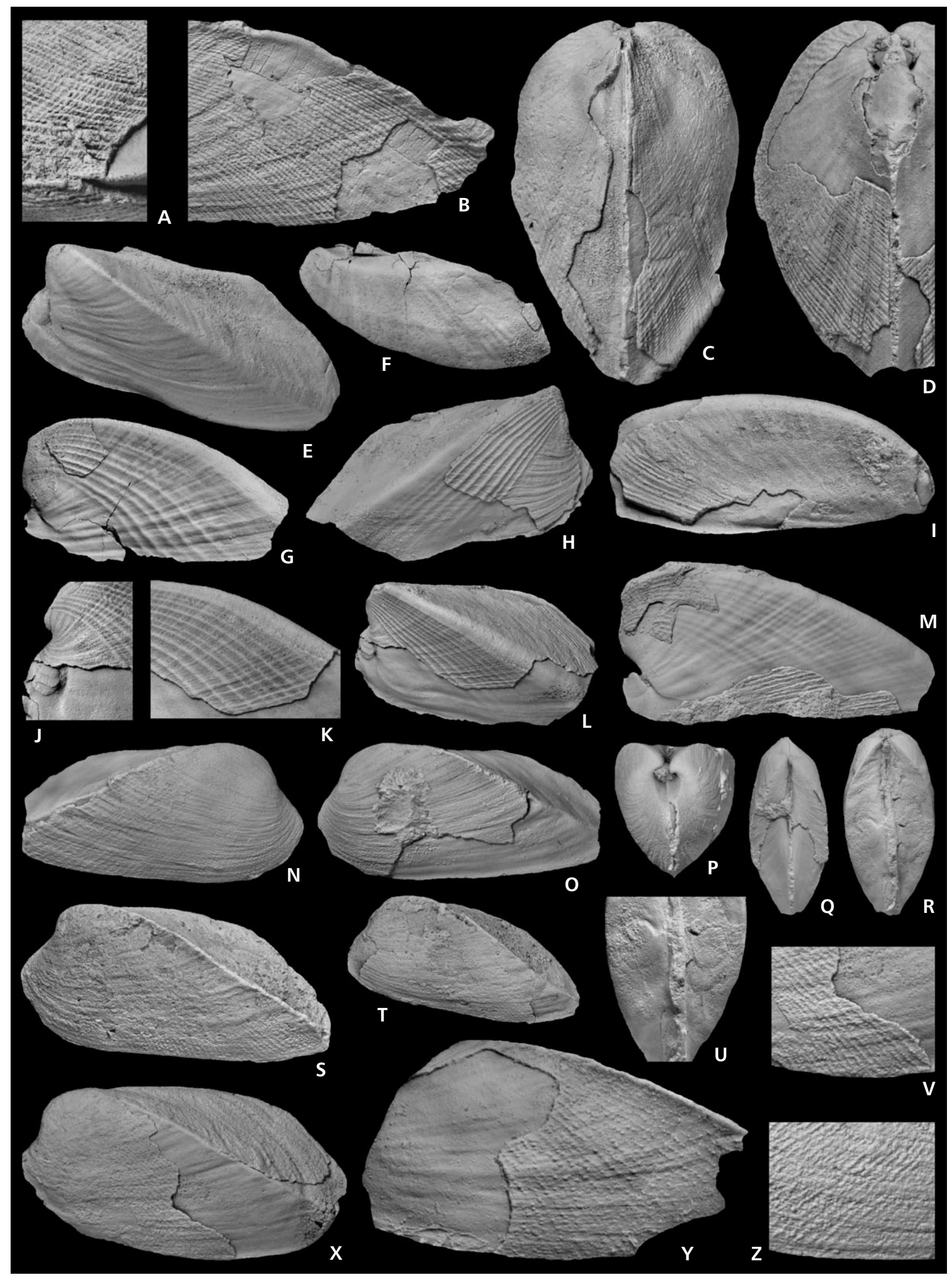


Description. - Shell longitudinally elongated ( $\mathrm{L} \geq 28.5$, $H \geq 12.6)$, equivalve, strongly inequilateral, obese ( $H / W$ $=1.5$ ). The shell has both anterior and posterior shell gapes. Umbones are prominent, beaks prosogyrate, in 1/4 of the length of shell from anterior. Dorsal margin is long, straight, almost parallel with the ventral margin, which is long, concave, and with ventral sinus. Posterior and anterior margins are rounded. Posterior part of the shell is higher than anterior and maximum width of the shell is about one fourth of the shell length from the posterior end. Outer surface sculpture is composed of the growth wrinkles and irregular narrow growth bands and furrows. Inner surface sculpture is similar. Muscle scars, hinge and ligament unknown. Shell thickness is $0.10-0.17 \mathrm{~mm}$.

\section{Dimensions. -}

$\begin{array}{llrrr}\text { specimen } & \mathrm{V} & \mathrm{L} & \mathrm{H} & \mathrm{W} / 2 \\ \mathrm{JK} 11738 & \mathrm{R} & 23.0 & 8.3 & 2.7 \\ \mathrm{JK} 11738 & \mathrm{R} & >28.5 & >12.6 & 4.3\end{array}$

Discussion. - Cymatonota prolata sp. nov. differs from the Wenlockian and Gorstian Cymatonota antiqua (Barrande, 1881) by distinctly longer shells and by the position of beak in $1 / 4$ of the length of shell from anterior. The Ludlow species is very similar to the type species of the genus, $C y$ matonota typicalis Ulrich, 1895 from the Upper Ordovician of U.S.A., which differs by subparallel dorsal and ventral margins.

Mode of life. - Infaunal, most probably burrowing (Pojeta 1971).

\section{Cimitaria Hall \& Whitfield, 1869}

Type species. - Cypricardites recurvus Conrad, 1842, U.S.A., New York, Middle Devonian, Hamilton Group.

\section{Cimitaria liscina sp. nov.} Figures 11E-P, 12A

Holotype. - Right valve with most of outer surface preserved, JK 11799, figured on Fig. 11M, N.
Paratypes. - JK 11800-JK 11809 measured for dimensions, included into community analysis, and figured on Figs 11E-L, 12A.

Derivation of name. - Derived from the Liščí Quarry near Amerika gamekeeper's lodge, Karlštejn, Bohemia.

Type locality. - Bohemia, Karlštejn, Liščí Quarry near Amerika gamekeeper's lodge.

Type horizon. - Silurian, Ludlow, lower Gorstian, Kopanina Formation, section No. 942/2.

Material. - Six shells with conjoined valves, four left, and three right valves.

Description. - Medium sized $(\mathrm{L}=44.0)$, elongated $(\mathrm{L} / \mathrm{H}=$ $3.28)$, equivalve, and inflated shells $(\mathrm{H} / \mathrm{W}=1.22-1.44)$. Umbones are prominent, extended above the dorsal margin, gibbous, and incurved, less than 1/5 of the shell length from anterior. Umbonal ridge is indistinct, rounded, and became obsolete before reaching posterior extremity. Posterior part of concave dorsal margin is curved upward. Posterior extremity of dorsal margin is obliquely truncated. Anterior part is short and rounded. Ventral margin is slightly concave, with weak ventral sinus, subparallel with the most of the dorsal margin. Lunule and long escutcheon are well developed. Outer surface sculpture consists of irregular growth wrinkles; ventrally of umbonal ridge distinct, convex, regularly spaced growth bands and furrows are developed. Surface sculpture of the anterior part of the shell is composed of narrow irregularly spaced growth bands and furrows. Posteriorly, in the wide radial sinus the number of growth bands decreases and they became wider and regularly spaced. Ligament opisthodetic, internal features and hinge unknown. Shell wall is thin $(0.14-0.31 \mathrm{~mm})$.

$\begin{array}{llrrr}\begin{array}{l}\text { Dimensions. - } \\ \text { specimen }\end{array} & \text { V } & \mathrm{L} & \mathrm{H} & \mathrm{W} / 2 \\ \text { JK } 11701 & \mathrm{~L} & 12.5 & 7.1 & 3.1 \\ \text { JK } 11804 & \mathrm{R} & 17.1 & 9.1 & - \\ \text { JK } 11802 & \mathrm{~L} & 19.6 & 10.1 & 3.5 \\ \text { JK } 11805 & \mathrm{~L} & >21.2 & 11.0 & 4.5 \\ \text { JK } 11799 & \mathrm{R} & 44.0 & 13.4 & 5.5\end{array}$

Figure 11. A, B - Goniophorina nitidula sp. nov.; A - articulated specimen, left view, JK 11771, paratype, $\times 2$; B - left valve, dorso-lateral view, JK 11785, × 3.6. - C, D - Cymatonota prolata sp. nov., right valve, JK 11738, holotype; C - lateral view, $\times 4.75$; D - dorso-lateral view, $\times$ 3.7. - E-P - Cimitaria liscina sp. nov.; E, F - articulated specimen, JK 11701, paratype; E - dorsal view, $\times$ 5.5; F - right view, $\times 2.35$; G, H - left valve, JK 11800, paratype; G - lateral view, × 2.5; H - dorso-lateral view, $\times 2.9 ; \mathrm{I}-\mathrm{K}$ - articulated specimen, JK 11801 , paratype; I-right view, $\times 2$; J - left view, $\times 2.3 ; \mathrm{K}-$ left view, detail of anterior part, $\times 3.1 ; \mathrm{L}$ - right valve, JK 11803, paratype, $\times 3.4 ; \mathrm{M}, \mathrm{N}-$ right valve, JK 11799, holotype; $\mathrm{M}$ - lateral view, $\times 1.95 ; \mathrm{N}$ - dorso-lateral view, $\times 3$; O, P - articulated specimen, JK 11802, paratype; O - dorsal view, $\times 1.7 ; \mathrm{P}-$ left view, $\times 2.5$. 


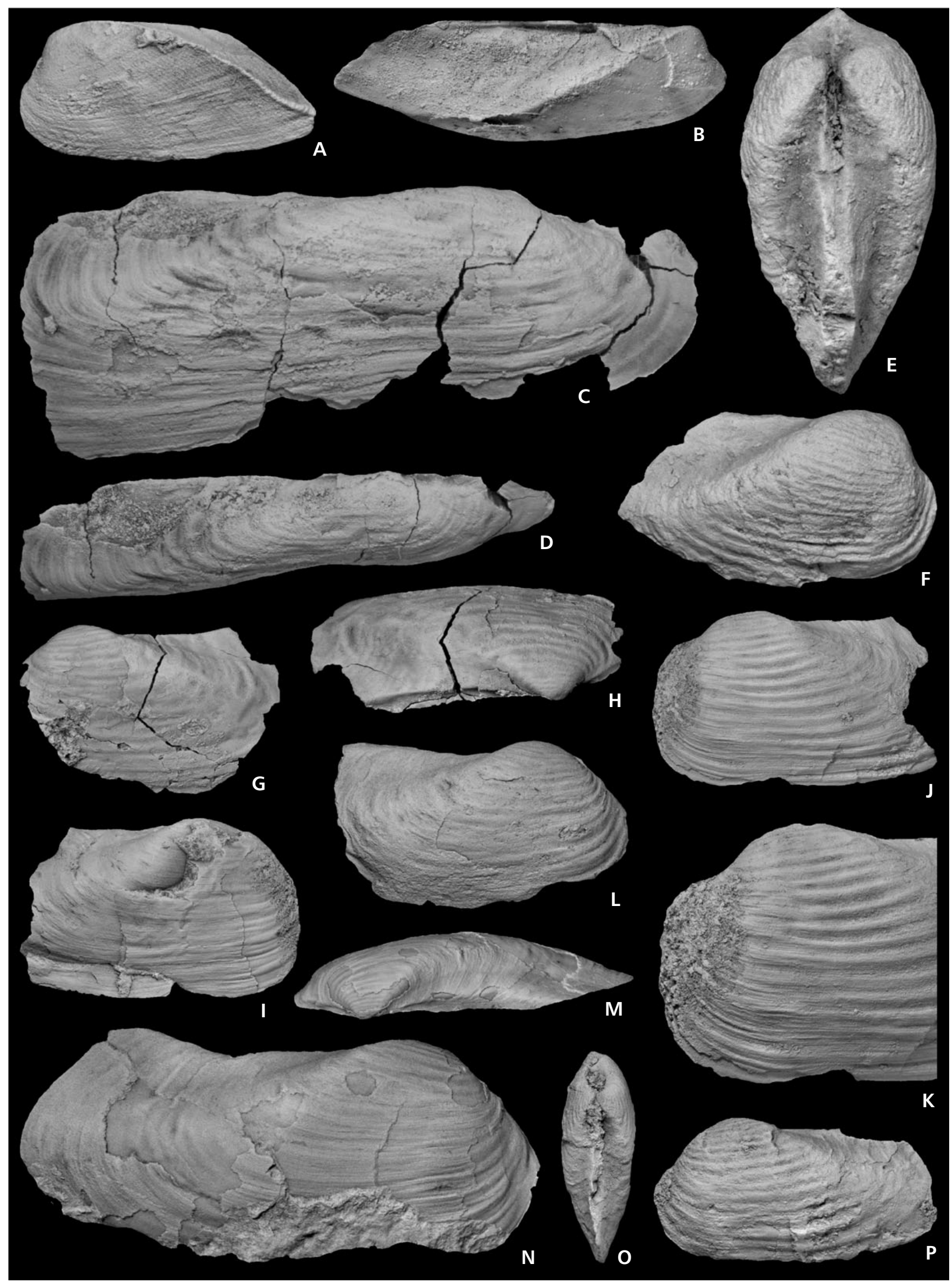


Discussion. - Cimitaria liscina sp. nov. is the earliest known representative of the genus for which the most characteristic feature is the concave dorsal margin. Pojeta et al. (1986) described from the middle Emsian, Lower Devonian of Guangxi, China Cimitaria sinensis Pojeta, Zhang \& Yang. From Cimitaria recurva (Conrad, 1842) from Givetian, Devonian of Michigan and New York, U.S.A., and from most of the other species of Cimitaria from the Middle and Upper Devonian New York, U.S.A. (Hall 1885). Cimitaria liscina differs by an indistinct umbonal ridge, by smaller shells and by the development of distinct regular convex growth bands and furrows in outer and inner surface sculpture of the shell ventrally of umbonal ridge and posteriorly of the weak radial sinus.

Mode of life. - Infaunal.

\section{Sanguinolites McCoy, 1844}

Type species. - Sanguinolites discors McCoy, 1844, Ireland, Lower Carboniferous.

Remarks. - Prominent growth bands and furrows are developed in the outer sculpture of the genera Cymitaria Hall and Whitfield, 1869 from the Middle and Upper Devonian of New York, U.S.A. and North American Upper Devonian genus Sanguinolites McCoy, 1844 with generally similar general shape. Also generally similar Grammysioidea Williams \& Breger, 1916 from the lower Silurian to Upper Devonian of the North, South America and Europe is lacking regular growth bands and furrows in outer surface sculpture.

\section{Sanguinolites? drupa sp. nov.} Figure 12B-G

Holotype. - Shell with conjoined valves with most of the outer surface preserved, JK 11698, figured on Fig. 12C-G.

Paratypes. - Three shells with conjoined valves, JK 11699-JK 11701, and one left valve, JK 11702, measured for dimensions, included into community analysis, and figured on Fig. 12B.

Derivation of name. - From Latin drupa, an overripe, wrinkled olive; indeclinable noun.

Type locality. - Bohemia, Karlštejn, Liščí Quarry near Amerika gamekeeper's lodge.

Type horizon. - Silurian, Ludlow, lower Gorstian, Kopanina Formation, section No. 942/2.
Material. - Four shells with conjoined valves and one left valve.

Diagnosis. - The Ludlow Sanguinolites? with outer surface sculpture composed of prominent numerous growth bands and furrows in combination with numerous fine radial costellae in the growth furrows.

Description. - Medium size shell $(\mathrm{L}=12.5-44.0 ; \mathrm{H}=$ 7.1-23.4; $\mathrm{W}=6.3-19.8)$, transverselly subovate, equivalve, inequilateral, elongated $(\mathrm{L} / \mathrm{H}=1.56-1.92)$, and distinctly obese $(\mathrm{H} / \mathrm{W}=1.13-1.37)$. Umbones are prominent, in anterior position, closely incurved, prosogyrate. Umbonal ridge is indistinct, rounded, and became obsolete before reaching posterior extremity. Lunule and escutcheon are well defined, escutcheon bordered by narrow ridge. Dorsal margin is long, straight. Anterior part is relatively long, lobate, separated from the rest of the shell by wide, ventrally widening shallow radial sulcus. Ventral margin is long, slightly convex. Posterior margin rounded. Outer surface sculpture is composed of the growth wrinkles and prominent convex growth bands and furrows in combination with numerous, irregularly spaced, short radial riblets. Growth bands increase in number posteriorly of anterior part by intercalation or bifurcation, usually starting in the radial sulcus or posteriorly of it. Growth bands and furrows disappear dorsally of umbonal ridge. Inner surface sculpture is composed of the growth bands and furrows only. Muscle scars and hinge unknown. Shell thickness is $0.14-0.37 \mathrm{~mm}$.

$\begin{array}{lrrr}\begin{array}{l}\text { Dimensions. }- \\ \text { specimen }\end{array} & & & \\ \text { JK } 11698 & 34.1 & \text { H } & \text { W } \\ \text { JK } 11699 & 45.0 & >23.8 & 15.9 \\ & & \end{array}$

Discussion. - The ancestral Wenlockian species from the Barrande's locality "hills between Loděnice and Bubovice”, Sanguinolites? bialata (Barrande, 1881), figured by Barrande on pl. 261, figs I/1-7 as Leda bialata (NM L 27022-L 27023) and Sanguinolites? solida (Barrande, 1881) figured on pl. 261, figs IV/1-7 as Modiolopsis solida (NM L 27 019-L 27 020) are most probably conspecific and represent most probably oldest known species of Sanguinolites?. They differ from Sanguinolites? drupa by less robust shells with shallow radial sulcus separating posterior wing; outer and inner surface sculpture is composed of less convex numerous growth bands and furrows. The radial riblets developed on Sanguinolites? drupa are not preserved on Barrande's types from the Wenlock. Sanguinolites nagaolingensis Pojeta et al., 1986 from the Lower Devonian Nagaoling Formation of Guangxi, China has very similar outer surface sculpture, formed by growth bands and furrows, increasing in number in anterior part of the shell by intercalation or bifurcation. Sanguinolites? 


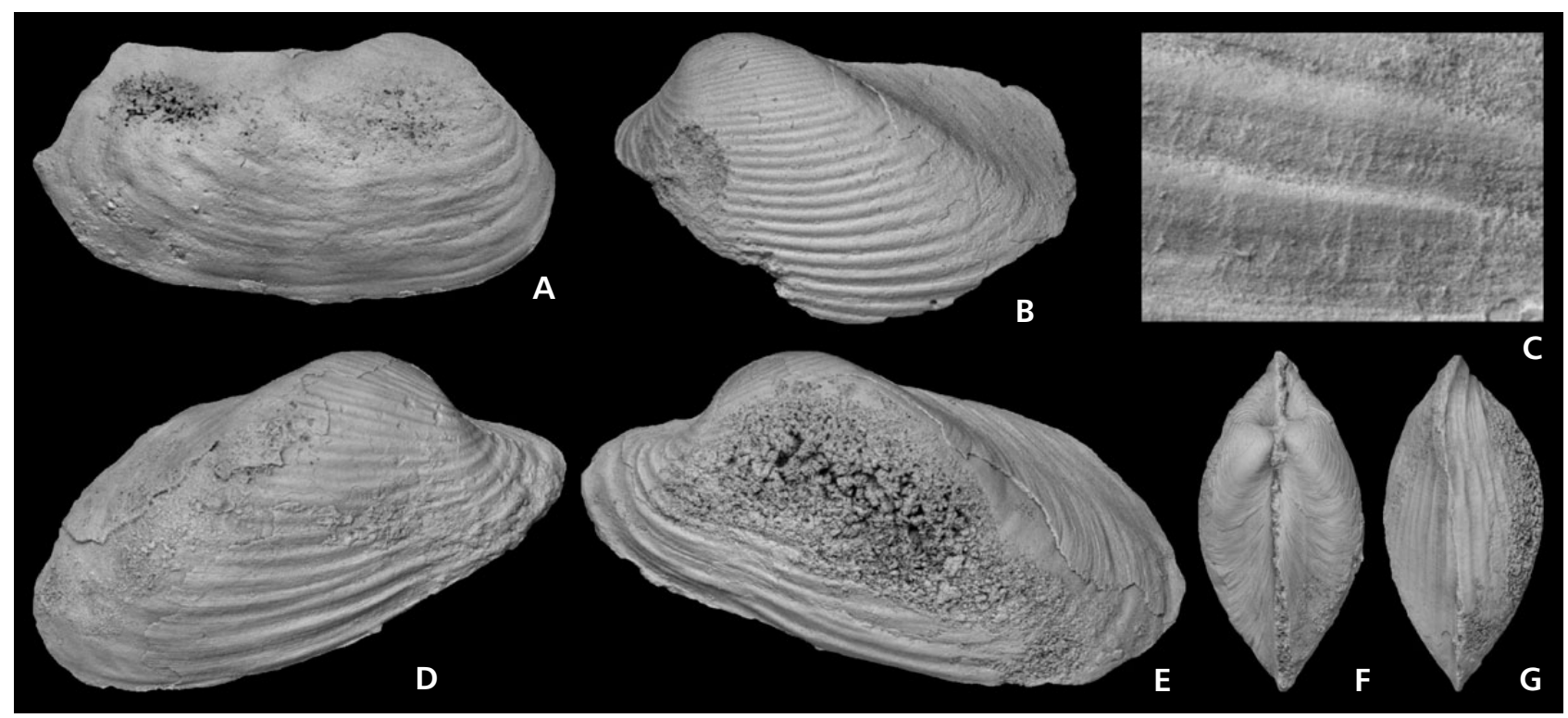

Figure 12. A-Cimitaria liscina sp. nov., right lateral view, JK 11804, ×4.9. •B-G - Sanguinolites? drupa sp. nov.; B - left valve, JK 11702, paratype, $\times 2.8 ; \mathrm{C}-\mathrm{G}-$ articulated specimen, JK 11698 , holotype; $\mathrm{C}-$ right view, detail of the outer surface sculpture, $\times 6 ; \mathrm{D}-$ right view, $\times 1.7 ; \mathrm{E}-$ left view, $\times 1.7$; $\mathrm{F}-$ dorsal view, $\times 1$; $\mathrm{G}-$ ventral view, $\times 0.95$.

drupa differs from Chinese species by distinctly obese shells, the longer anterior part, separated from the rest of the shell by radial sulcus, by not parallel dorsal and ventral margin, and by numerous, fine radial riblets presented in outer surface sculpture. Similar general shape, relatively long, lobate anterior part is developed only in the modiomorphid Whiteavesia cincinnatensis (Hall \& Whitfield, 1875) from the Upper Ordovician of Kentucky, U.S.A., but it differs in lacking the coarse growth bands and ventral sinus (Pojeta 1971, pl. 17, figs 1-15). Similar features may be seen on internal mould of Whiteavesia sp. from the Upper Ordovician, lower Ashgill of Siberian Platform, Russia (Krasilova 1979). The type species Sanguinolites discors McCoy, 1844, from the Lower Carboniferous of Ireland differs from Sanguinolites? drupa by prominent umbonal carina, elongated, less inflated shells and by angular posterior part of the dorsal margin which is not parallel with ventral margin and by distinctly long anterior lobate part.

Mode of life. - Probably semi-infaunal.

\section{Community analysis}

The Bivalvia dominated communities from the Silurian and Lower Devonian carbonates of the Bohemian type bivalves were classified by Kř́̌ž (1999a) into the five natural community groups, each containing homologous and analogous communities (Boucot \& Kř́ž 1999). These community groups are related to the cephalopod limestone biofacies (Cardiola Community Group), to the contemporary deeper water micritic limestone biofacies (Cheiopteria Community Group), to the Přídolí and Lower Devonian soft bottom micritic limestone biofacies (Snoopyia Community Group and Patrocardia Community Group) and to the soft bottom Lower Devonian biomicritic to biodetritic biofacies (Antipleura-Hercynella Community Group).

\section{Coral-Crinoid Community Group}

Havlíček \& Štorch (1990, 1999) described shallow water Coral-Crinoid Community from the Liščí Quarry near Amerika gamekeeper's lodge near Karlštejn. They interpreted the community as a biostrome characterized by prevalence of crinoids, corals, stromatoporoids accompanied by bivalves, brachiopods, gastropods, and trilobites (Horný 1962).

The shallow water coral-crinoid biofacies is known in the Prague Basin, Bohemia in the upper Wenlock (Homerian), lower Ludlow (Gorstian) and in the Lower Devonian (Lochkovian and Pragian). The Bivalvia communities developed in this biofacies are not analogous and homologous with the other Bivalvia community groups described by Kříž (1999a). For that I propose for this type of the communities the term Coral-Crinoid Community Group. It includes for example the homologous and analogous late Homerian, Wenlock Coral-Leptaenid Community, Hircinisca-Ancillotoechia Community, and Septatrypa lissodermis-Cyrtia maior Community, the early Gorstian, Ludlow Atrypa fumosa Community, the Lochkovian Warburgella Community 
Table 1. The Janicula potens Community highest rank abundance bivalves occurrence in the levels A-E of the layer 2, section No. 942 , lower Gorstian, Ludlow, Silurian, Liščí Quarry near Amerika gamekeeper's lodge, Karlštejn, Prague Basin, Bohemia. L - left valves, R - right valves, A - valves with conjoined valves.

\begin{tabular}{|c|c|c|c|c|c|c|c|c|c|c|c|c|c|c|c|}
\hline \multicolumn{3}{|c|}{$\mathbf{A}$} & \multicolumn{3}{|c|}{ B } & \multicolumn{3}{|c|}{$\mathrm{C}$} & \multicolumn{3}{|c|}{ D } & \multicolumn{3}{|c|}{ E } & \multirow{2}{*}{$\frac{\text { LEVEL }}{\text { VALVES }}$} \\
\hline $\mathbf{L}$ & $\mathbf{R}$ & $\mathbf{A}$ & $\mathbf{L}$ & $\mathbf{R}$ & $\mathbf{A}$ & $\mathbf{L}$ & $\mathbf{R}$ & $\mathbf{A}$ & $\mathbf{L}$ & $\mathbf{R}$ & $\mathbf{A}$ & $\mathbf{L}$ & $\mathbf{R}$ & $\mathbf{A}$ & \\
\hline 1 & 1 & 9 & 34 & 57 & 29 & 176 & 193 & 68 & 63 & 66 & 31 & 3 & 3 & 6 & Janicula potens \\
\hline- & 1 & 1 & 14 & 19 & 1 & 53 & 59 & 10 & 39 & 21 & 12 & - & - & - & Goniophorina nitidula \\
\hline 1 & - & 1 & 8 & 4 & 8 & - & 3 & - & 3 & 7 & 1 & - & - & - & Goniophora compta \\
\hline- & - & 1 & 8 & 6 & - & 7 & 5 & - & 6 & 2 & 1 & - & - & - & Goniophora sp. \\
\hline - & 2 & 1 & 4 & 3 & - & 7 & 5 & 2 & 4 & 7 & 1 & - & - & - & Goniophora tyri \\
\hline 2 & 2 & - & 7 & 8 & - & 3 & 2 & - & 5 & 3 & - & - & - & - & Mytilarca sp. \\
\hline- & - & - & - & - & - & 16 & 13 & - & 6 & 1 & - & - & - & - & Molinicola bohemica \\
\hline 2 & - & - & 2 & - & - & 8 & 5 & - & 1 & 1 & - & - & - & - & Palaeopecten radvani \\
\hline 2 & - & - & - & 3 & 5 & - & 1 & 1 & - & - & - & - & - & - & Goniophora ascia \\
\hline 1 & - & - & 7 & 6 & - & 2 & - & - & 2 & 2 & - & - & - & - & Amphicoelia pojetana \\
\hline- & - & - & 5 & - & - & 4 & 3 & - & 4 & - & - & 1 & - & 1 & Mytilarca parens \\
\hline - & - & - & 6 & - & - & 5 & 2 & - & 6 & - & - & - & - & - & Rhombopteria perunicola \\
\hline- & - & - & 1 & - & - & 3 & 1 & 2 & 3 & 3 & 1 & 1 & - & - & Macrodesma enigma \\
\hline - & - & - & 2 & 3 & 5 & - & - & - & 2 & - & - & - & - & - & Cimitaria liscina \\
\hline- & 1 & - & 1 & 2 & - & 2 & 3 & 1 & 1 & 1 & - & - & 1 & - & Mimerodonta phaseolus \\
\hline
\end{tabular}

and Coniproetus-Protocymostrophia Community (Havlíček \& Štorch 1999). To this community group also correspond the new lower Gorstian Janicula potens Community from the coral-crinoid biofacies in the Liščí Quarry.

\section{Janicula potens Community}

Name. - Used here for the first time.

Community group assignment. - Coral-Crinoid Community Group.

Composition. - 32 species of bivalves: Slava sathon, Cardiola donigala, Cardiola signata, Cardiola aff. geminans, Dualina amina, Mila parvula, Algerina aff. algena, Tetinka costulifera, Macrodesma enigma, Phthonia regularis, Ambonychia volitans, Amphicoelia pojetana, Mytilarca parens, Mytilarca sp., Molinicola bohemica, Palaeopecten radvani, Palaeopecten sp., Rhombopteria perunicola, Praeostrea bohemica, Butovicella migrans, Mimerodonta phaseolus, Janicula potens, Goniophora tyri, Goniophora ascia, Goniophora compta, Goniophora solci, Goniophora sp., Goniophorina nitidula, Cymatonota prolata, Cimitaria liscina, Cimitaria cf. liscina, and Sanguinolites? drupa, together with abundant gastropods (60 species), brachiopods (26), corals (31), trilobites (11), rostroconchids (4), and crinoids (12), common cephalopods (13), and stomatoporoids (3), and relatively rare ostracods (2), tergomyans (1), polyplacophorids (1), worms (1), bryozoans (3), algae (1), and sponges.

Age. - The coral-crinoid biofacies is not favourable for graptolites and their preservation. The correlation should be based on the benthic and nektobenthic organisms. The bivalves Slava sathon, Cardiola donigala, Butovicella migrans, and Cardiola signata occur in the contemporaneous cephalopod limestone biofacies Cardiola donigala - Slava sathon Community described from the lower parts of the Saetograptus chimaera Biozone, lower Gorstian, Ludlow (Manda \& Kř́ž 2007). Algerina aff. algena is very closely related to Algerina algena described from the lower Gorstian of Algeria (Kř́rž 2008) where it represents a dominant species of the $A l$ gerina algena - Cardiola agna agna Subcommunity in the cephalopod limestone biofacies of the Colonograptus colonus Biozone. All these species represent in the Janicula potens Community low rank species and marginal occurrences of the bivalves dominant or common in cephalopod limestone biofacies Cardiola dominated communities.

On the other side brachiopods with the dominant Atrypa fumosa Havlíček in Havlíček \& Štorch, 1990 may be correlated with the nearby locality Kozolupy, Kouřící Quarry, where Atrypa fumosa occurs just above the lower Gorstian Atrypoidea renitens Community (Havlíček \& Štorch 1990). Trilobite Cromus storchi (Šnajdr, 1983), one of the dominant species of the trilobite assemblage from the Liščí 
Table 2. Numerical and ranked abundance of bivalves in the Janicula potens Community, lower Gorstian, Ludlow, Silurian, Lišči Quarry near Amerika gamekeeper's lodge, Karlštejn, Bohemia. R+L - right and left valves (disarticulated), A - shells with conjoined valves, RA - percentage relative abundance, AA - percentage relative abundance of shells with conjoined valves, $\mathrm{R}$ - rank abundance.

\begin{tabular}{|c|c|c|c|c|c|c|}
\hline species & life habits & $\mathrm{R}+\mathrm{L}$ & A & RA & AA & $\mathrm{R}$ \\
\hline Janicula potens & infaunal & 895 & 179 & 59.30 & 28.52 & 1 \\
\hline Goniophorina nitidula & infaunal & 257 & 53 & 17.18 & 29.20 & 2 \\
\hline Goniophora compta & semi-infaunal & 31 & 16 & 2.98 & 50.79 & 3 \\
\hline Goniophora sp. & semi-infaunal & 57 & 2 & 2.89 & 13.11 & 4 \\
\hline Goniophora tyri & semi-infaunal & 44 & 4 & 2.46 & 15.38 & 5 \\
\hline Mytilarca sp. & epifaunal & 43 & - & 2.04 & - & 6 \\
\hline Molinicola bohemica & semi-infaunal & 40 & - & 1.89 & - & 7 \\
\hline Palaeopecten radvani & semi-infaunal & 30 & - & 1.42 & - & 8 \\
\hline Goniophora ascia & semi-infaunal & 11 & 8 & 1.28 & 29.63 & 9 \\
\hline Amphicoelia pojetana & epifaunal & 26 & - & 1.23 & - & 10 \\
\hline Rhombopteria perunicola & reclining & 23 & 1 & 1.19 & 8.00 & 11 \\
\hline Mytilarca parens & epifaunal & 22 & 1 & 1.14 & 8.33 & 12 \\
\hline Macrodesma enigma & infaunal & 14 & 3 & 0.95 & 30.00 & 13 \\
\hline Cimitaria liscina & infaunal & 7 & 6 & 0.90 & 63.16 & 14 \\
\hline Mimerodonta phaseolus & semi-infaunal & 15 & 1 & 0.80 & 11.76 & 15 \\
\hline Phthonia regularis & infaunal & - & 4 & 0.38 & 100.00 & 16 \\
\hline Sanguinolites? drupa & semi-infaunal & 1 & 3 & 0.33 & 85.71 & 17 \\
\hline Goniophora solci & semi-infaunal & 6 & - & 0.28 & - & 18 \\
\hline Cardiola donigala & epifaunal & 6 & - & 0.28 & - & 18 \\
\hline Palaeopecten sp. & semi-infaunal & 4 & - & 0.19 & - & 19 \\
\hline Dualina amina & reclining & 1 & 1 & 0.14 & 66.67 & 20 \\
\hline Butovicella migrans & epifaunal & 3 & - & 0.14 & - & 20 \\
\hline Cimitaria cf. liscina & infaunal & 2 & - & 0.09 & - & 21 \\
\hline Tetinka costulifera & infaunal & - & 1 & 0.09 & 100.0 & 21 \\
\hline Cardiola signata & semi-infaunal & 2 & - & 0.09 & - & 21 \\
\hline Algerina aff. algena & reclining & 1 & - & 0.05 & - & 22 \\
\hline Slava sathon & infaunal & 1 & - & 0.05 & - & 22 \\
\hline Ambonychia volitans & epifaunal & 1 & - & 0.05 & - & 22 \\
\hline Cymatonota prolata & infaunal & 1 & - & 0.05 & - & 22 \\
\hline Cardiola aff. geminans & semi-infaunal & 1 & - & 0.05 & - & 22 \\
\hline Praeostrea bohemica & reclining & 1 & - & 0.05 & - & 22 \\
\hline Mila parvula & reclining & 1 & - & 0.05 & - & 22 \\
\hline Totals & & 1547 & 283 & $100.01 \%$ & $26.79 \%$ & \\
\hline
\end{tabular}

Quarry locality, occurs in the lower Gorstian, Colonograptus colonus Biozone in the section No. 687 between Arethusina Gorge and Mušlovka Quarry near Praha-Řeporyje (Křǐz 1992). It may be concluded that the Janicula potens Community is the lower Gorstian, Saetograptus chimaera Biozone in age.

Type locality. - Bohemia, Karlštejn, Liščí Quarry near Amerika gamekeeper's lodge.

Geographic distribution. - The Janicula potens Community is analogous and homologous with the similar lower Homerian, upper Wenlock communities of bivalves of which species were described by Barrande (1881) from the vicinity of Loděnice, Tachlovice, Svatý Jan (Hliník), Kozel near Beroun and Lištice in the Prague Basin, Bohemia.

Very closely related are the Silurian reef bivalves described by Watkins (1997) from the upper Wenlock Racine Formation of Wisconsin and Illinois, North America. The reefs are located on open marine shelves. In total the Racine Formation Bivalvia community consists of 15 species, mostly epibyssate, semi-infaunal, reclining and also free burrowing, including Amphicoelia, Mytilarca, Goniophora, Rhombopteria and Cardiola. The community is analogous and homologous with the Janicula potens Community. 
Environment interpretation. - The bivalves occur in presumably bioturbated environment of partly unconsolidated biodetrital limestone (Fig. 1, section No. 942, bed No. 2) with high tuffaceous admixture together with abundant crinoids, corals, gastropods, commonly articulated brachiopods and other benthic and nektobenthic fauna. The relatively thick layers $(15-30 \mathrm{~cm})$, of grey green tuffites containing rarely lapilli (up to a tens of milimeters large) represent the evidence of periodical disturbance of the environment by volcanic activity of the nearby (ca $2.5 \mathrm{~km}$ ) Svatý Jan Volcano.

Polyplacophoran molluscs are preserved as isolated sclerites. Bivalves are mostly not fragmented, except the largest infaunal, semi-infaunal, and epibyssate bivalves (Slava, Amphicoelia, Palaeopecten, and Mytilarca). High-spired gastropods are mostly preserved as large fragments (Horný 1952), but in general the gastropods are not fragmented and were not transported postmortally (Horný \& Peel 1995). Interesting is the observation of a large, adult specimen of the belleropohontoidean Boiotrermus incipiens (Barrande in Perner, 1903) with a large injury caused presumably by a small volcanic bomb (Horný 1998).

Cephalopod shells are commonly found with body chambers. Abundant crinoids are mostly disarticulated. Tabulate coral colonies are frequently overturned. Large branched rugose coral colonies (Microplasma flexuosum Prantl, 1939a) at the base of the green tuffite bed between the levels B and $\mathrm{C}$ are preserved in living position.

The Janicula potens Community is highly diversified (32 species of bivalves) and has quite high population densities. The bivalves are well preserved, mostly disarticulated but also abundant shells with conjoined valves $(26.79 \%)$. In the soft-bottom environment the most abundant are infaunal bivalves (11 species - 78.99\%). Dominant Janicula potens (59.30\%), and Goniophorina nitidula (17.18\%), were probably burrowing species and their shells with conjoined valves are very common (percentage relative abundance is quite high $28.52 \%$ and $29.20 \%$ ). The community also contains relatively high number of the semi-infaunal (10 species $-14.66 \%$ ), epifaunal ( 7 species $4.88 \%$ ), and reclining (5 species $-1.48 \%$ ) bivalves, some of them also with still common shells with conjoined valves (Goniophora). The idea about autochthonous community with minimal transport is supported by the common preservation of the infaunal bivalves as shells with conjoined valves together with a little fragmented large Palaeopecten and Amphicoelia shells.

Gastropods represent the most diversified group at the locality. Horný \& Peel (1995) estimated more than 60 species. High-spired murchisonoideans, oriostomatids, and bellerophontoideans are most characteristic. Very abundant Oriostoma Munier-Chalmas, 1876 and Tophicola Horný \& Peel, 1995 were most probably epifaunal sedentary ciliary feeders (Horný 1995, Horný \& Peel 1995).
They were well adapted against fine periodically dispersed volcanic ash by the heavy, massive operculum. The dominant Euomphalopterus cf. aliger Barrande in Perner, 1907 (thousands of specimens have been collected) was probably also deposit feeder characterized by a wide flange at the whorl periphery which may be an adaptation to prevent sinking into a soft substratum by increase in surface area (Peel \& Wängberg-Eriksson 1979). Some of the gastropods were grazers that lived on algal foliage (Peel 1978). The community is most probably homologous and analogous with the "soft-bottom, shallow marine shallow platform fauna" described from the Silurian Arisaig Group, Nova Scotia, Canada (Peel 1978).

The co-occurring well diversified brachiopod community is dominated by Atrypa fumosa Havlíček in Havlíček \& Štorch, 1990, Isorthis (Arcualla) manon Havlíček, 1977, Sufetirhynchia radvani (Havlíček, 1961), Atrypinella fuxa Havlíček in Havlíček \& Štorch, 1990, Meristina mora Michalík, 1970, and Kirkidium (Pinguaela) bohemicum (Přibyl, 1943). Most of the brachiopods were found articulated in the tuffaceous limestones together with bivalves and gastropods. The relatively large brachiopod Meristina mora is mostly found articulated in life position, in groups, forming nests in a small channels and depressions filled with the green tuffite (Michalík 1970). According to Havlíček \& Štorch (1999) the brachiopod community inhabited the top of a submarine elevation built up of volcaniclastic rocks of the Wenlock and the lowermost Ludlow age.

The trilobite Sphaerexochus-Proetus Assemblage (Chlupáč 1987) and benthic fauna from the Liščí Quarry was interpreted as autochtonous and typical of an extremely shallow water environment of active volcanic elevations and mostly above the wave base.

It may be concluded that the Janicula potens Community together with other benthic organism most probably inhabited well-ventilated shallow-water flats, overgrown locally by algae, with biodetrite carbonate sedimentation influenced and periodically interrupted by direct ash fall and by the subsequent sedimentation of volcaniclastics by currents around the volcanic archipelago. The environment was most probably protected against direct wave action by the local bars of crinoidal sands with the biolitic frame built by tabulate (mainly favositids, halysitids, and heliolitids) and rugose (microplasmid) coral colonies. The occurrence of quite abundant isolated sclerites of polyplacophoran molluscs indicates nearness of the high energy, tidal, reefshoal environments (Cherns 1999). The Janicula potens Community, with its 32 bivalve species, is the most diversified Bivalvia community in the Silurian of the Prague Basin. It shows close palaeogeographic relationships with the upper Wenlock, Racine Formation reefs of Wisconsin and Illinois, North America (Watkins 1997) and Silurian of Gotland and Dalarna (Sweden), Maine (North America), 
and Nova Scotia (Canada). The Liščí Quarry lower Gorstian tuffaceous limestones, with more than 202 species benthic and nektobenthic organisms known, represent the most fossiliferous Silurian locality in the Prague Basin.

\section{Acknowledgements}

I am indebted to John C.W. Cope, National Museum of Wales, Cardiff, and John Pojeta, Jr., U.S. Geological Survey, Washington, D.C., for valuable suggestions, constructive comments and linguistic improvement. I thank to Radvan Horný from the National Museum, Prague for helpful discussions, for providing the locality Liščí Quarry section details and for the exchange of bivalves for gastropods during collecting at the locality Liščí Quarry in 1965-1966. I also thank to Štěpán Manda for his assistance with drafting some of the figures and for his help with the petrography and lithology questions. Vojtěch Turek and Martin Valent, National Museum, Prague kindly provided access to the collections. The research was funded by GA ČR (Czech Science Foundation) project 205/06/1367.

\section{References}

BARRANDE, J. 1881. Systême silurien du centre de la Bohême. Classe des Mollusques, ordre des Acéphalés 6. 342 pp., 356 pls. Prague \& Paris.

BEURLEN, K. 1944. Beiträge zur Stammesgeschichte der Muscheln. Sitzungsberichte der Bayerischen Akademie der Wissenschaften, Mathematisch-naturwissenschaftiche Klasse 1-2, 133-145.

BILlings, E. 1874. Geological Survey of Canada, Palaeozoic fossils. Volume 2, part 1. 144 pp., 85 text figs, 9 pls. Dawson Brothers, Montreal.

BouCOT, A.J. \& KŘíž, J. 1999. Definition of the terms "homologous" and "analogous" community, 32. In BOUCOT, A.J. \& LAWSON, J.D. (eds) Paleocommunities: a case study from the Silurian and Lower Devonian. World and Regional Geology Series 11. Cambridge University Press, Cambridge, $\mathrm{xv}+895 \mathrm{pp}$.

BOUČEK, B. 1931. On several new fossil rich localities in the Lower Paleozoic of Central Bohemia. Věda př́rodni 12. [in Czech]

CHERnS, L. 1999. Silurian chitons as indicators of rocky shores and lowstand on Gotland, Sweden. Palaios 14, 172-179. DOI $10.2307 / 3515372$

CHLUPÁČ, I. 1987. Ecostratigraphy of Silurian trilobite assemblages of the Barrandian area, Czechoslovakia. Newsletters in Stratigraphy 17(3), 169-186.

CONRAD, T.A. 1842. Observations on the Silurian and Devonian systems of the United States, with descriptions of new organic remains. Journal of the Academy of Natural Science of Philadelphia 8(2), 228-280.

COPE, J.C.W. 1996. Early Ordovician (Arenig) bivalves from the Llangynog Inlier, South Wales. Palaeontology 39, 979-1025.

DAHMER, G. 1921. Studien über die Fauna des Oberharzer
Kahlenberg-Sandsteins, II. Jahrbuch der Koniglich Preussichen Geologischen Landesanstalt, Berlin für 1919, 40(2), 161-306.

DALL, W.H. 1889. On the hinge of pelecypods and its development with an attempt toward a better subdivision of the group. American Journal of Sciences, Third Series, 38(228), 445-462.

DUFKA, P. 1995. Upper Wenlock miospores and cryptospores derived from a Silurian volcanic island in the Prague Basin (Barrandien area, Bohemia). Journal of Micropalaeontology 14, 67-79.

FISCHER, P. 1880-87. Manuel de conchyliologie et de paléontologie conchyliologique ou histoire naturelle des mollusques vivants et fossiles. 1880, pp. 1-112; 1881, pp. 113-304; 1882, pp. 305-416; 1883, pp. 417-608; 1884, pp. 609-688; 1885, pp. 689-896; 1886, pp. 897-1008; 1887, pp. 1009-1369. F. Savy, Paris.

GRAY, J.E. 1847. A list of the genera of Recent Mollusca, their synonyms and types. Proceedings of the Royal Zoological Society, London, 15, 129-219.

GrobBen, K. 1894. Zur Kenntniss der Morphologie, Verwandschaftsverhältnisse und des Systems der Mollusken. Sitzungsberichte der Kaiserlichen Akademie der Wissenschaften. Mathematisch-naturwissenschaftliche Klasse 103, 61-86.

HALL, J. 1847. Natural History of New York. Paleontology. Vol. 1.338 pp., 88 pls. Geological Survey of New York, New York.

HALL, J. 1860. Descriptions of new fossils from the Silurian rocks of Nova Scotia. Canadian Naturalist and Geologist 5, 144-159.

HALL, J. 1865. Account of some new or little known species of fossils from rocks of the age of the Niagara group. New York State Cabinet of Natural History, $18^{\text {th }}$ Annual Report, advance publication, 1-16.

HALL, J. 1867. Descriptions of some new fossils from the Niagara Group. New York State Cabinet of Natural History, $20^{\text {th }}$ Annual Report, 308-401.

HALL, J. 1883. Lamellibranchiata, plates and explanations. Natural History of New York, Paleontology 5(1), 1-20, 79 pls.

HALL, J. 1885. Lamellibranchiata II, descriptions and figures of the Dimyaria of the Upper Helderberg, Hamilton, and Chemung groups. New York Geological Survey, Paleontology 5(1), 1-268, pls 34-80, 93-96.

HAll, J. \& Whitfield, R.P. 1869. Preliminary notice of the lamellibranchiate shells of the Upper Helderberg, Hamilton and Chemung groups, with others from the Waverly sandstones. Part 2.80 pp. New York State Museum, Albany.

HALL, J. \& WHITFIELD, R.P. 1872. Description of new species of fossils from the vicinity of Louisville, Kentucky, and the Falls of the Ohio. New York State Museum of Natural History, $24^{\text {th }}$ Annual Report, 181-200a.

HALL, J. \& WHITFIELD, R.P. 1875. Descriptions of invertebrate fossils, mainly from the Silurian System. Ohio Geological Survey Report 2, Geology and Palaeontology 2, Palaeontology, 65-161.

HAVLÍČEK, V. 1961. Rhynchonelloidea des böhmischen älteren 
Paläozoikums (Brachiopoda). Rozpravy Ústředního ústavu geologického 27, 1-211.

HAVLÍČEK, V. 1977. Brachiopods of the Order Orthida in Czechoslovakia. Rozpravy Ústředního ústavu geologického $44,1-326$.

HAVlíčEK, V. \& ŠTORCH, P. 1990. Silurian brachiopods and benthic communities in the Prague Basin (Czechoslovakia). Rozpravy Ústredního ústavu geologického 48, 1-275.

HAVlíčEK, V. \& ŠTORCH, P. 1999. Silurian and Lochkovian communities in the Prague basin (Barrandian area, Czech Republic), 200-228. In BOUCOT, A.J. \& LAWSON, J.D. (eds) Final report, project Ecostratigraphy. Paleocommunities: A case study from the Silurian and Lower Devonian. 895 pp. Cambridge University Press, Cambridge.

HoERnES, R. 1884. Elemente der Palaeontologie. 594 pp. Veit and Company, Leipzig.

HORNÝ, R. 1952. Two new representatives of the family Murchisonidae Koken (Gastropoda) from the Silurian of Central Bohemia. Sborník Ústředního ústavu geologického, Oddíl paleontologický 19, 209-228, pls 5, 6 .

HORNÝ, R. 1955. The Budňany Beds in the western part of the Silurian of the Barrandian. Sborník Ústředního ústavu geologického, Oddíl geologický21(1954, 2), 315-447. [in Czech]

HORNÝ, R. 1962. Das mittelböhmische Silur. Geologie 11(8), 873-916.

HORNÝ, R.J. 1995. Adapertural location of the retractor muscle attachment area in Oriostoma (Mollusca, Gastropoda): a consequence of mode of life. Časopis Národního muzea, $\breve{R} a d a$ př́rodovědná 166(1-4), 39-44.

HORNÝ, R.J. 1998. A large injury and shell repair in Boiotremus incipiens (Mollusca, Gastropoda) from the Silurian of Bohemia. Věstník Českého geologického ústavu 73(4), 343-345.

HORNÝ, R.J. \& PEEL, J.S. 1995. A new Silurian gastropod from Bohemia with the operculum in situ. Journal of the Czech Geological Society 40(4), 79-84.

ISBERG, O. 1934. Studien über Lamellibranchiata des Leptaenakalkes id Dalarna. 493 pp. Håkan Ohlssons, Lund.

JACKSON, R.T. 1890. Phylogeny of the Pelecypoda; the Aviculidae and their allies. Memoirs of the Boston Society of Natural History IV, 277-400, pls 23-30.

JOHNSTON, P.A. 1991. Systematics and ontogeny of a new bivalve, Umburra cinefacta, from the Silurian of Australia: implications for pteriomorphian evolution. Alcheringa 15, 293-319. DOI 10.1080/03115519108619025

KEEN, A.M. 1958. Marine shells of tropical West America. 624 pp. Stanford University Press, Stanfrod, California.

KorobKOV, I.A. 1960. Family Rhombopteriidae Korobkov, fam. n., 81. In EBERZIN, A.G. Molluscs - loricates (amphineurs), bivalves, scaphopods. Fundamentals in palaeontology. 230 pp. Izdatelstvo Akademii Nauk SSSR, Moskva. [in Russian]

KRASILOVA, I.N. 1959. New family Leiopectinidae from the upper Silurian and Lower Devonian sediments of the north-eastern Pribalchasie. Paleontologicheskii Zhurnal 3, 41-46. [in Russian]

KRASILOVA, I.N. 1963. Stratigraphy and pelecypods of the upper
Silurian and Lower Devonian of the north-eastern Pribalchasie. Trudy Geologicheskogo Instituta Akademii Nauk SSSR 75, 1-202, 14 pls. [in Russian]

Krasilova, I.N. 1979. II. Pelecypods of the Mangazejsko, Dolorsko and Ketsko Horizons, 79-130. In PEIVE, A.V. (ed.) Ordovician fauna of Middle Siberia. Transactions of the Academy of Sciences of USSR 330, 1-240. [in Russian]

KŘ́ǐz, J. 1965. Genus Butovicella gen. n. in the Silurian (Bivalvia). Věstník Ústředního ústavu geologického 40, 207-208.

KŘíž, J. 1966. Praeostrea Barrande, 1881 from the lower Paleozoic of Central Europe (Bivalvia). Časopis Národního muzea, Oddíl prírodovědný 135, 25-32.

KŘíž, J. 1969. Genus Butovicella Kříž, 1965 in the Silurian of Bohemia (Bivalvia). Journal of Geological Sciences, Palaeontology 10, 105-139.

Kř́ǐ̌, J. 1979. Silurian Cardiolidae (Bivalvia). Sborník geologických věd, Palaeontologie 22, 1-160, 40 pls.

KŘíž, J. 1982. Slavinka gen. n. and Slavidae fam. n. (Bivalvia) from the Silurian of Bohemia. Věstník Ústředního ústavu geologického 57(4), 237-240.

KŘíž, J. 1985. Silurian Slavidae (Bivalvia). Sborník geologických věd, Palaeontologie 27, 47-111, 20 pls.

KŘíž, J. 1986. Silurian, 26-33. In HAVLÍČEK, V. (ed.) Explanation of the geological map ČSSR $1: 25$ 000, 12-414 Černošice. 84 pp. Ústřední ústav geologický, Praha. [in Czech]

KŘíž, J. 1991. The Silurian of the Prague Basin (Bohemia) - tectonic, eustatic and volcanic controls on facies and faunal development, 179-203. In BASSETT, M.G., LANE, P.D. \& EDWARDS, D. (eds) The Murchison Symposium: proceedings of an international conference on The Silurian System. Special Papers in Palaeontology 44, 1-397.

KŘíž, J. 1992. Silurian field excursions: Prague Basin (Barrandian) Bohemia. National Museum of Wales, Geological Series 13, 1-111.

KŘíž, J. 1996. Silurian Bivalvia of Bohemian type from the Montagne Noire and Mouthoumet Massif, France. Palaeontographica A 240, 29-63, 6 pls.

KŘíž, J. 1998. Silurian, 79-101. In CHLUPÁČ, I., HAVLÍČEK, V., KŘíž, J., KukAl, Z. \& ŠToRCH, P. Paleozoic of the Barrandian (Cambrian to Devonian). 183 pp. Český geologický ústav, Praha.

KŘíž, J. 1999a. Bivalvia dominated communities of Bohemian type from the Silurian and Lower Devonian carbonate facies, 229-252. In BouCOT, A.J. \& LAWSON, J.D. (eds) Final report, project Ecostratigraphy. Paleocommunities: A case study from the Silurian and Lower Devonian. 895 pp. Cambridge University Press, Cambridge.

KŘíž, J. 1999b. Cephalopod limestone biofacies on the northern slopes of the Silurian volcanic archipelago in the Prague Basin containing re-described benthic Cardiola donigala-Slava cubicula Community (Bivalvia, Barrandian, Bohemia). Journal of the Czech Geological Society 44(1-2), 159-165.

KŘíž, J. 1999c. Silurian and lowermost Devonian bivalves of Bohemian type from the Carnic Alps. Abhandlungen der Geologischen Bundesanstalt 56, 259-316.

KŘíž, J. 2001. Enantiomorphous dimorphism in Silurian and De- 
vonian bivalves; Maminka Barrande, 1881 (Lunulacardiidae, Silurian) - the oldest known example. Lethaia 34, 309-322. DOI $10.1080 / 002411601753293060$

KŘíž, J. 2006. Bohemian type bivalves Praeostrea bohemica Barrande, 1881 and Slavinka plicata (Barrande, 1881) from the Silurian and earliest Devonian of the Carnic Alps (Austria). Bulletin of Geosciences 81(2), 147-149.

DOI 10.3140/bull.geosci.2006.02.147

KŘíž, J. 2007. Origin, evolution and classification of the new superorder Nepiomorphia (Mollusca, Bivalvia, Lower Paleozoic). Palaeontology 50(6), 1341-1365. DOI $10.1111 /$ j.1475-4983.2007.00720.x

Ǩ̌íž, J. 2008. Algerina gen. nov. (Bivalvia, Nepiomorphia) from the Silurian of the North Gondwana margin (Algeria), periGondwanan Europe (France, Italy), Perunica (Prague Basin, Bohemia) and the Siberian Plate (Tajmyr Basin, Russia). Bulletin of Geosciences 83(1), 79-84. DOI 10.3140/bull.geosci.2008.01.079

KŘ́lŽ, J. \& BogOlEPOVA, O.K. 1995. Cardiola signata Community (Bivalvia) in cephalopod limestones from Tajmyr (Gorstian, Silurian, Russia). Geobios 28(5), 573-583. DOI 10.1016/S0016-6995(95)80212-6

KŘ́lŽ, J., DUFKA, P., JAEGER, H. \& SCHÖNLAUB, H.P. 1993. Wenlock-Ludlow boundary in the Prague Basin (Bohemia). Jahrbuch der Geologischen Bundesanstalt 136(4), 809-839.

KŘíž, J. \& SERPAGLI, E. 1993. Upper Silurian and lowermost Devonian Bivalvia of Bohemian type from south-western Sardinia. Bolletino della Società Paleontologica Italica 32, 289-347.

KUKAL, Z. 1955. Investigation of the Silurian dolomite limestone at Velká Mořina. Sborník Ústředního ústavu geologického, Oddíl geologický 21(1954, 2), 225-251.

LILJEDAHL, L. 1984. Silurian silicified bivalves from Gotland. Sveriges Geologiska Undersökning, Serie C, NR 804, 78(2), $1-82$.

LILJEDAHL, L. 1989. Identity of the bivalve Modiodonta gothlandica (Hisinger) from the Silurian of Gotland. Geologiska Föreningens i Stockholm Förhandlingar 111(4), 313-318.

LILJEDAHL, L. 1992. Silurozodus, new genus, the oldest known member of the Trigonioida (Bivalvia, Mollusca). Paläontologische Zeitschrift 66(1/2), 51-65.

LILJEDAHL, L. 1994. Silurian nuculoid and modomorphid bivalves from Sweden. Fossils and Strata 33, 1-89.

LINDSTRÖM, G. 1880. In ANGELIN, N.P. \& LINDSTRÖM, G. 1880. Fragmenta Silurica e Dono Caroli Henrici Wegelin. 39 pp. Samson \& Wallin, Stockholm.

LINNÉ, C. 1758. Systema naturae per regna tria naturae, secundum classes, ordines, genera, species, cum characteribus, differentiis, synonymis, locis. 824 pp. Editio Decima, reformata, Holmiae.

MANDA, ك̌. \& BUDIL, P. 2007. Stop E1-6: Ludlow and early Př́idolí succession at Mušlovka Quarry near Řeporyje; early Ludfordian radiation and the effect of the Ludfordian extinction events in the shallow-water carbonate succession, 25-34. In ELICKI, O. \& SCHNEIDER, E. (eds) Fossile Ökosysteme. Wissenschaftliche Mitteilungen, Institut für Geologie, Technische Universität Bergakademie Freiberg 34.
MANDA, Š. \& KŘíž, J. 2007. New cephalopod limestone horizon in the Ludlow (Gorstian, lower L. scanicus Biozone) of the Prague Basin (Bohemia, Perunica). Bolletino della Società Palaeontologica Italiana 46(1), 33-45.

MCCOY, F. 1844. A synopsis of the characters of the Carboniferous Limestone fossils of Ireland. 274 pp., 29 pls. Privately printed. Re-issued 1862, Williams \& Norgate, London.

McCoY, F. 1851. On some new Silurian Mollusca. Annals and Magazine of Natural History, Series 2, 7(37), 45-63.

MCLEARN, F.H. 1918. The Silurian Arisaig Series of Arisaig, Nova Scotia. American Journal of Science 45, 126-140.

MCLEARN, F.H. 1924. Palaeontology of the Silurian rocks of Arisaig, Nova Scotia. Memoir of the Geological Survey of Canada 175(118), 1-179.

MichALÍK, J. 1970. Genus Meristina Hall, 1867 in the Silurian of the Barrandian in Central Bohemia. Sborník geologických věd, Paleontologie 12, 135-170, 4 pls.

MiLLER, S.A. 1877. The American Palaeozoic fossils, a catalogue of the genera and species. 253 pp. Published by author, Cincinnati.

MunieR-Chalmas, E. 1876. Molusques noveaux des terrains paléozoïques des environs de Rennes. Journal de Conchiologie, $3^{e}$ série, 16, 102-109.

NEUMAYR, M. 1891. Beiträge zu einer morphologischen Eintheilung der Bivalven. Denkschriften der Kaiserlichen Akademie der Wissenschaften, Mathematisch-naturwissenschaftliche Klasse 58, 701-801.

NEWELL, N.D. 1965. Classification of the Bivalvia. American Museum Novitates 2206, 1-25.

NEWELL, N.D. 1969. Family Cyrtodontidae Ulrich, 1894, 248-250, and superfamily Pholadomyacea Gray, 1847, 818-823. In MOORE, R.C. (ed.) Treatise on Invertebrate Paleontology. Part N, Mollusca 6, Bivalvia. 487 pp. Geological Society of America \& University of Kansas Press, Boulder \& Lawrence.

NEWELL, N.D. \& BOYD, D.W. 1975. Parallel evolution in early trigoniacean bivalves. Bulletin of the American Museum of Natural History 154(2), 55-162.

MURCHISON, R.I. 1839. The Silurian System founded on geological researches in the counties of Salop, Hereford, Radnor, Montgomery, Caermarthen, Brecon, Pembroke, Monmouth, Gloucester, Worcester and Stafford; with descriptions of the coalfields and overlying formations. i-xxxii, $768 \mathrm{pp}$. John Murray, London.

MURCHISON, R.I. \& VERNEUIL, E. 1844. Note sur les équivalents du système permiens en Europe, suivie d'un coup d'oeil general sur l'ensemble de ses fossiles, et d'un tableau des espèces. Bulletin de la Société Géologique de France, $2^{e}$ série, 1, 475-517.

PEEL, J.S. 1978. Faunal succession and mode of life of Silurian gastropods in the Arisaig Group, Nova Scotia. Palaeontology 21(2), 285-306.

PEEL, J.S. \& WÄNGBERG-ERIKSSON, K. 1979. Gastropods, 105-108. In JAANUSSON, V., LAUFELD, S. \& SKOGLUND, R. (eds) Faunal and Floral Dynamics - Vattenfallet Section, Gotland. Sveriges Geologiska Undersökning, Arsbok 73(3), Serie C 762,1-294. 
PERnER, J. 1903. Systême silurien du centre de la Bohême. Gastéropodes 4(1). 164 pp., 89 pls. Prague \& Paris.

PERNER, J. 1907. Systême silurien du centre de la Bohême. Gastéropodes 4(2). 380 pp., pls. 90-175. Prague \& Paris.

PERNER, J. 1911. Systême silurien du centre de la Bohême. Gastéropodes 4(3). 390 pp., pls 176-247. Prague \& Paris.

PHILLIPS, J. 1848. The Malvern hills, compared with the Palaeozoic districts of Abberley, Woolhope, May Hill, Tortworth, and Usk. Memoirs of the Geological Survey of Great Britain 2(2), 1-330.

POJETA, J. JR. 1962. The pelecypod genus Byssonychia as it occurs in the Cincinnatian at Cincinnati, Ohio. Palaeontographica Americana 4(30), 170-216.

POJETA, J. JR. 1966. North American Ambonychiidae (Pelecypoda). Palaeontographica Americana 5(36), 131-241.

POJETA, J. JR. 1971. Review of Ordovician Pelecypods. U.S. Geological Survey Professional Paper 695, 1-46, 20 pls.

POJETA, J. JR., ZHANG, R. \& YANG, Z. 1986. Systematic palaontology of the Devonian pelecypods of Guangxi and Michigan, 57-102. In POJETA, J. JR. (ed.) Devonian rocks and Lower and Middle Devonian pelecypods of Guangxi, China, and the Traverse Group of Michigan. U.S. Geological Survey Professional Paper $1394-A-G, 1-108,66$ pls.

PRANTL, F. 1939a. Some Silurian rugose corals from Bohemia. Rozpravy České akademie věd a umění, Třída II 49(14), 1-11 pp, 1 pl. [in Czech]

PRANTL, F. 1939b. Occurrence of Spongophylloides Meyer in the Silurian of Bohemia. Rozpravy České akademie věd a umění, Trída II 49(18), 1-7, 1 pl. [in Czech]

PRANTL, F. 1957. Über die Gattung Helminthidium Lindström aus dem böhmischen Silur (Rugosa). Sborník Ústředního ústavu geologického, Oddíl paleontologický 23(1956), 475-496. [in Czech]

PŘIBYL, A. 1943. On the genus Conchidium Linnaeus from the Silurian of Bohemia. Rozpravy České akademie věd a umění, Tř́da II 53(13), 1-19, 4 pls. [in Czech]

RAFINESQUE, C.S. 1815. Analyse de la nature ou tableau de l'Univers et des corps organisés. 224 pp. Jean Barravecchia, Palermo.

RoHR, D.M. 1999. Lower Silurian to Lower Devonian gastropod communities, 132-136. In BoUCOT, A.J. \& LAWSON, J.D. (eds) Final report, project Ecostratigraphy. Paleocommunities: A case study from the Silurian and Lower Devonian. 895 pp. Cambridge University Press, Cambridge.

RŮŽIČKA, B. \& PRANTL, F. 1959. The hinge aparatus of the genus Goniophora Phillips (Pelecypoda). Sborník Národního muzea v Praze, Řada B - prírodní vědy 15(1), 48-60.

RŮŽIČKA, B. \& PRANTL, F. 1961. Note on the determination of taxa of fossil pelecypods. Časopis Národního muzea v Praze, Oddíl př́rodovědný 130(1), 81-82. [in Czech]

RŮŽIČKA, R. \& BOUŠKA, J. 1944. Silurian fossils from the "Amerika" Quaries near Velká Mořina (Bohemia). Věda př́rodní 22(7), 189-193. [in Czech]
SÁNCHEZ, T.M. 2005. New Bivalvia and Rostroconchia from the early Ordovician (Late Tremadoc-Middle Arenig) of northwestern Argentina. Journal of Paleontology 79(3), 532-541. DOI 10.1666/0022-3360(2005)079<0532:NBARFT>2.0.CO;2

SÁNCHEZ, T.M. 2006. Taxonomic position and phylogenetic relationships of the bivalve Goniophorina Isberg, 1934, and related genera from the early Ordovician of northwestern Argentina. Ameghiniana (Revista de la Asociatión Paleontologica Argentina) 43(1), 113-122.

SinICYNA, I.N. 1964. Representatives of the Modiolopsidae Fischer from the Silurian sediments of Podolia. Vestnik Leningradskogo Universiteta 24, 44-50. [in Russian]

STAROBOGATOV, Y.I. 1977. Systematic position of conocardiids and the system of the Paleozoic Septibranchia (Bivalvia). Byulleten' Moskovskogo Obshchestva Ispytatelei Prirody, Otdel Geologicheskii 52(4), 125-139. [in Russian]

SVOBODA, J. \& PRANTL, F. 1955. On the stratigraphy and tectonics of the older Paleozoic in the wider vicinity of Karlštejn. Sborník Ústředního ústavu geologického, Oddíl geologický 21 (1954, 1), 519-596. [in Czech]

ŠNAJDR, M. 1983. New Silurian trilobites from Bohemia. Věstník Ústředního ústavu geologického 57(3), 175-178.

ULRICH, E.O. 1894. The Lower Silurian Lamellibranchiata of Minnesota, from Volume 3. Final Report of the Geological and Natural History Survey of Minnesota, 475-628, pls 35-42. (Published and distributed under separate cover prior to publication of the entire Volume 3 in 1897.)

ULRICH, E.O. 1895. New and little known Lamellibranchiata from the Lower Silurian of Ohio and adjacent states. Ohio Geological Survey Report 7(2), 627-693, pls 45-56.

WAHLENBERG, G. 1821. Petrificata telluris Suecanae. Kunglige Vetenskaps-societeten i Uppsala, Nova acta Regiae Societatis Scientiarum Upsalliensis 8, 1-116.

WALMSLEY, V.G. 1962. The identity and a new description of Pteronitella retroflexa (Wahlenberg) from the Upper Silurian of Gotland and the Welsh Borders. Geologiska Föreningens Förhandlingar 84(4), 351-362.

WATKINS, R. 1997. Paleoecology of Silurian reef bivalves, Racine Formation, North America. Lethaia 29, 171-180.

DOI 10.1111/j.1502-3931.1996.tb01873.x

WiLliaMS, H.S. 1912. Some new Mollusca from the Silurian formations of Washington county, Maine. Proceedings of the United States National Museum 42, 381-401, pls 49, 50.

WILLIAMS, H.S. 1913. New species of Silurian fossils from the Edmunds and Pembroke formations of Washington County, Maine. Proceedings of the United States National Museum 45, 319-352, pls 29-31.

WILLIAMS, H.S. \& BREGER, C.L. 1916. The fauna of the Chapman Sandstone of Maine, including descriptions of some related species from the Moose River sandstone. U.S. Geological Survey Professional Paper 89, 1-347, 27 pls. 